\title{
ipen
}

INSTITUTO DE PESQUISAS ENERGÉTICAS E NUCLEARES

Autarquia Associada à Universidade de São Paulo

\section{ANÁLISE TÉCNICO ECONÔMICA DE UNIDADES GERADORAS DE ENERGIA DISTRIBUÍDA}

\author{
Henrique de Senna Mota
}

Dissertação apresentada como parte dos requisitos para obtenção do Grau de Mestre em Ciências na Área de Tecnologia Nuclear.

Orientadora:

Dra. Fátima Maria Sequeira de Carvalho

São Paulo

2011 


\section{DEDICATÓRIA}

A quem não pede nada e em troca dá amor, Ao que não desespera, pois sabe o seu valor, A todos que a tristeza não conseguiu vencer,

Ao que aposta alto sem medo de perder, A todos que hoje sentem coragem pra sonhar, Ao que partiu agora e ao que quer regressar, Ao que semeia o trigo e ao que reparte o pão, Dedico este trabalho, de todo coração.

Adaptado de The Fevers - Boa Sorte 


\section{AGRADECIMENTOS}

Agradecimentos nem sempre são uma tarefa fácil ou justa. Por isto agradeço primeiro a todos que de alguma forma passaram pela minha vida e contribuíram para a construção deste trabalho.

Este mestrado não se resume apenas a uma dissertação, este que é o resultado de uma caminhada que se iniciou muito antes de estar em São Paulo. Mas, foi nesta cidade, que muitos dos sonhos, dos objetivos, passaram a ser tornarem mais reais. As amizades, o amadurecimento intelectual e pessoal é parte desta conquista.

Apesar da impossibilidade de expressar com clareza e simplicidade o que vivi neste período, tenho a certeza que um caminho foi construído e percorrido. É uma história de crescimento que jamais será esquecida, na qual me inspira em vôos mais altos.

Por isto, meu verdadeiro agradecimento vai a todos aqueles que têm no íntimo, a consciência de terem realmente contribuído para minha formação cuja orientação conduziu-me pelos caminhos do saber e a aqueles ausentes, cuja memória e os ensinamentos permanecem vivos.

Agradeço a Deus e seus colaboradores, por me dar mais força do que a fé na qual deposito a eles.

Aos grandes Pensadores. Pois "se eu vi mais longe, foi por estar sobre ombros de gigantes.”

A minha orientadora Fátima Carvalho por seu grande apoio, conselhos, auxílio, disponibilidade de tempo, sempre com uma simpatia e competência contagiante.

A Douglas Cassiano pela forte inspiração no amadurecimento dos meus conhecimentos, pela grande cooperação e parceria na execução deste trabalho.

Agradeço especialmente à minha mãe, Sueli Senna e ao meu tio Roque. Sem o grande apoio de vocês isto nunca seria possível. Meu muito obrigado, de coração. 
Meu carinho especial para João Milton Barbosa Leite e Thaísa Senna.

A Sandro Skoda, Paulinha Suzaki, André Senna, Mary Senna, Carlos Emílio Senna, Rosa Sena, Evandro José Silva, Thayne Yamamoto, Inâe Nascimento pelo esforço extra, amizade e companheirismo.

Ao CNPQ e ao IPEN pela bolsa concedida; ao ex-presidente Lula por seu incentivo a ciência.

Ao Bressiani, Fernando Moreira, Marcelo Linardi e Alfredo Alvim pelo apoio. Ao CCCH e CEN pelo espaço, equipamentos e recursos disponibilizados.

Aos professores Ivan Santos, Rodolfo Politano, Afonso Aquino, Antonio Carlos Barroso, Alberto Todo, Renato Semmler, Wagner Oliveira, Martha Vieira, Martha Simões Ribeiro, Eliana Navarro, L. A. Terremoto pelas lições aprendidas. Aos antigos professores Carlos Henriques Paixão e Ricardo Mendonça pelas lições não esquecidas.

Aos companheiros J. Vidal Bellineti e Eliana do CCCH.

Ao pessoal da secretaria do IPEN, informática e outros departamentos que me atenderam, e sempre me trataram com muita presteza e gentileza.

Ao pessoal da biblioteca, segurança, jardinagem, limpeza, cantina e refeitório por manter o ambiente sempre tão limpo e organizado.

Nesta caminhada muitas pessoas estiveram no meu lado e aqui presto minha homenagem pelo convívio, pelo apoio, pela compreensão e pela amizade: Vó Penha, Lígia Senna, Mariah Senna, Robinson Senna, Rosangela e Jundi Suzaki, Cláudia Lange, Walter “Baiano”, Pâmela Bock, Breno Senna, Clarinha Leite, Angela Mota, Vitor Mota, Meire Senna, Paschoal Sena, Priscila Sena, Akio Suzaki, Tamiris Leandro.

A todos os familiares pela paciência e dedicação. E aos tantos outros que sem dúvida não tem o nome aqui expresso mas que contribuíram nesta caminhada.

Finalmente a todos aqueles que se importam, meu muito obrigado! 
"We will make eletricity so cheap that only the rich will burn candles."

\section{Thomas Edison}

(Nós faremos a eletricidade tão barata que somente os ricos irão acender velas) 


\title{
ANÁLISE TÉCNICO ECONÔMICA DE UNIDADES GERADORAS DE ENERGIA DISTRIBUÍDA
}

\author{
Henrique de Senna Mota
}

\begin{abstract}
RESUMO
Neste trabalho analisou-se de forma técnica e econômica, diferentes unidades de geração elétrica. São elas: célula a combustível movida a hidrogênio, geração eólica, geração solar, geração hídrica, grupo moto gerador à diesel. Utiliza-se do software HOMER para simular o funcionamento das unidades geradoras. Ainda discute-se o tema energético, levanta-se os parâmetros de entrada, analisa-se as variáveis de sensibilidade e discute-se os resultados obtidos.
\end{abstract}

Palavras-Chave: Energia, HOMER, Geradores, Custos, Simulação, Investimento. 


\title{
TECHNICAL ECONOMIC ANALYSIS OF DISTRIBUTED POWER \\ GENERATION UNITS
}

\section{Henrique de Senna Mota}

\begin{abstract}
In this study was analyzed technically and economically, different units of electrical generation. There are: fuel cell powered by hydrogen, wind power, solar power, hydro power, diesel generator. Makes use of the HOMER software to simulate the runs of the generator units. Also discusses the energy theme, develop input parameters, analyzes the variables of sensitivity and discusses the results.
\end{abstract}

Key-Words: Energy, HOMER, Generators, Costs, Simulation, Investiment. 


\section{SUMÁRIO}

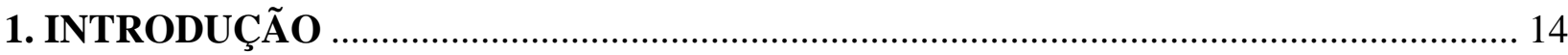

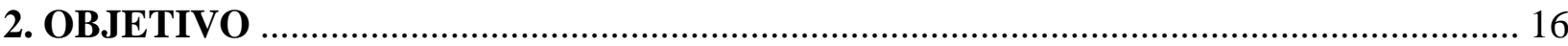

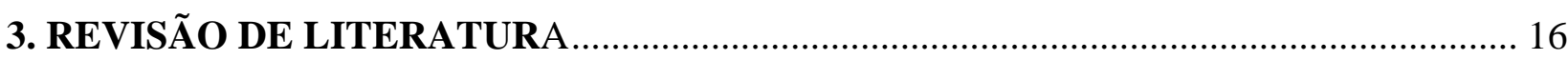

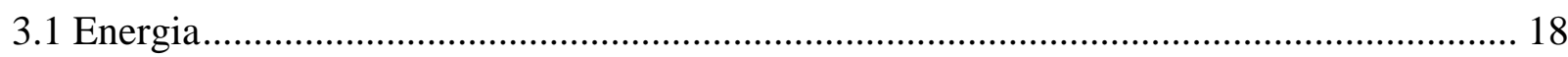

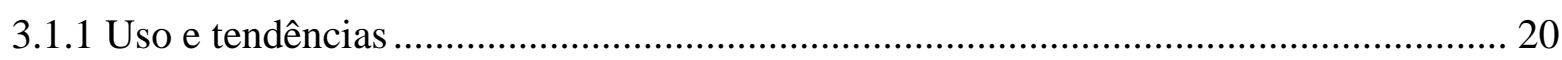

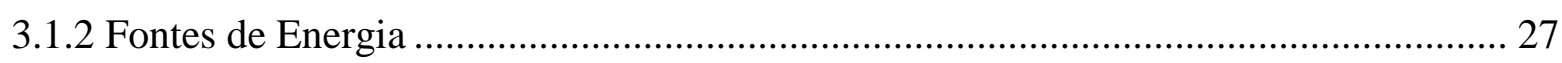

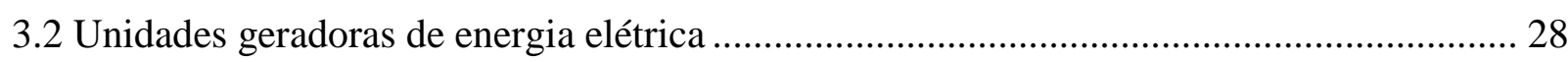

3.2.1 Célula Combustível ........................................................................................... 30

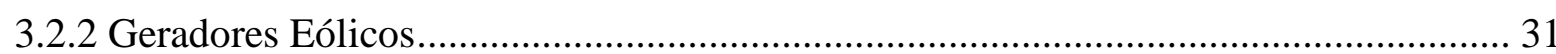

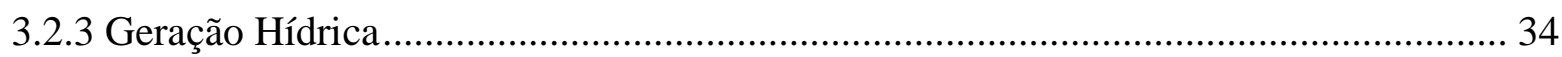

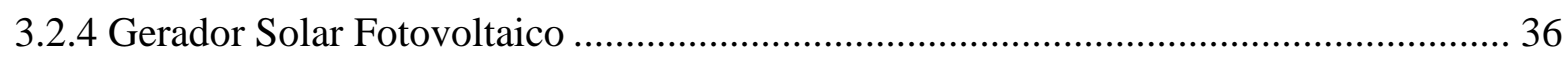

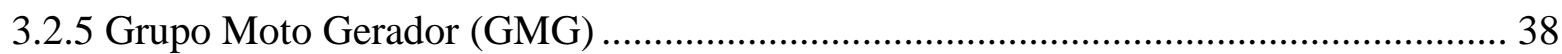

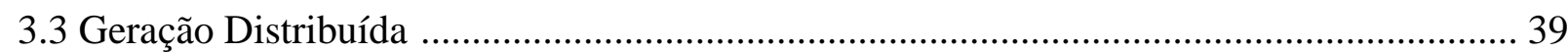

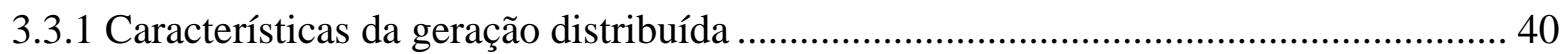

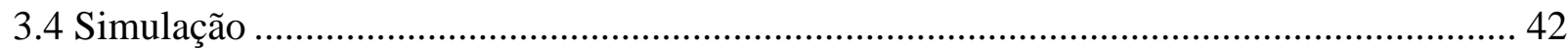

3.4.1 Software HOMER …………………………………...................................... 43

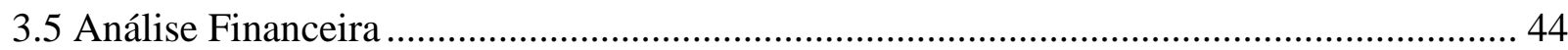

3.5.1 Valor Presente Líquido (VPL), Taxa Interna de Retorno (TIR) e Payback................. 44

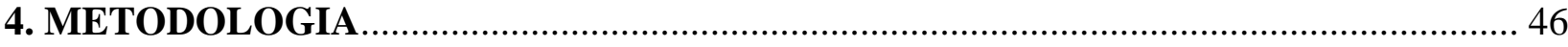

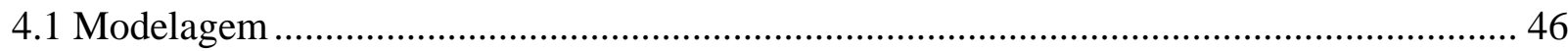

4.1.1 Utilização do software Homer ................................................................................ 46

4.1.2 Otimização e Análise de sensibilidade ........................................................................... 48

4.1.3 Cálculo do Valor Presente Líquido (VPL) ……………………………………….... 47

4.1.4 Cálculo da Taxa Interna de Retorno (TIR)............................................................... 48

4.1.5 Cálculo do payback descontado ............................................................................. 48

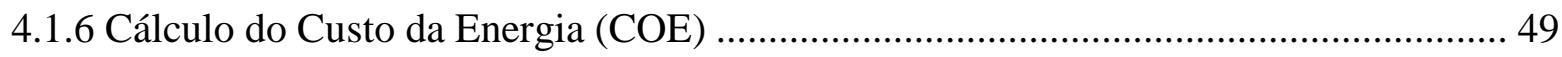

4.1.7 Cálculo do ponto de equilíbrio da rede....................................................................... 50

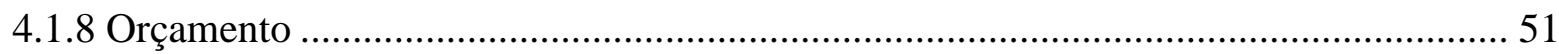

4.1.9 Viabilidade técnica e econômica .............................................................................. 51

4.1.10 Comparação entre alternativas de investimento ………………………………….... 52

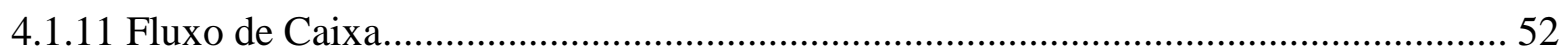

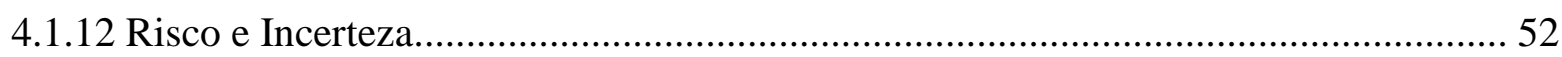

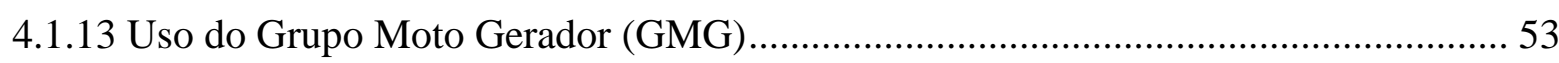




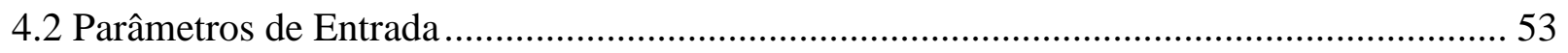

4.3.1 Demanda energética em kW do Local escolhido .................................................... 53

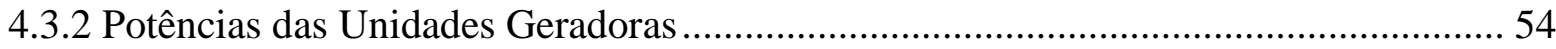

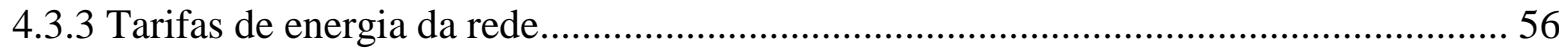

4.3.4 Custo para interligar o sistema à rede........................................................................ 59

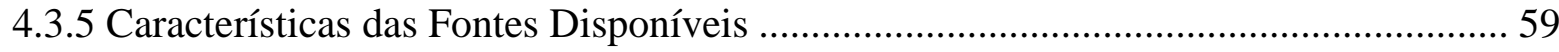

4.3.6 Custos das Unidades Geradoras e outros equipamentos ........................................... 61

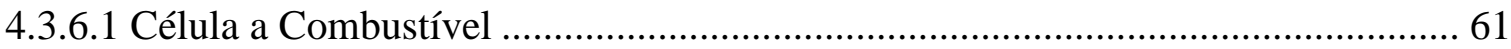

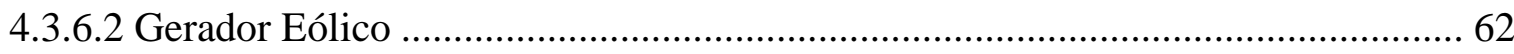

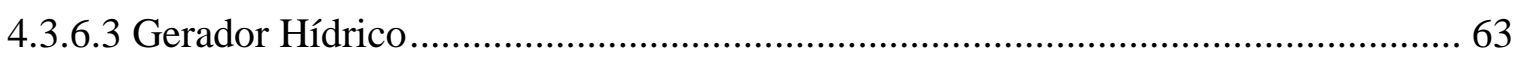

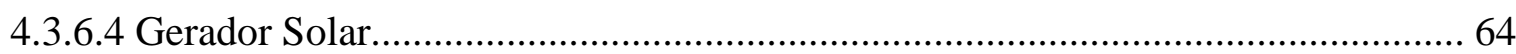

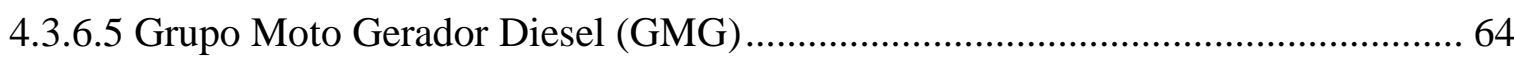

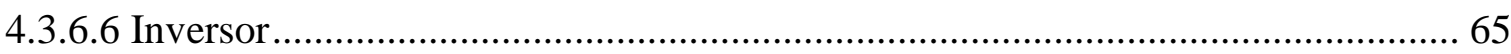

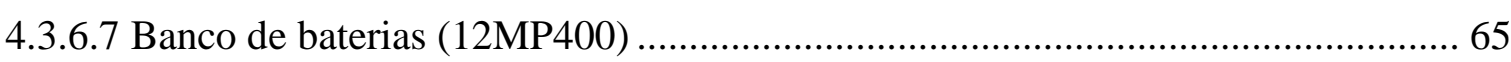

4.4.7 Quadro Resumo dos Custos e Operação ............................................................... 66

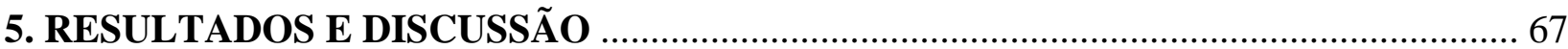

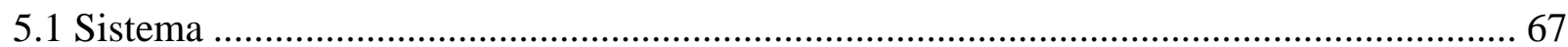

5.2 Cálculo do Valor Presente Líquido por sistema estudado ............................................... 69

5.3 Sistema autônomo x custo da ampliação da rede ............................................................. 71

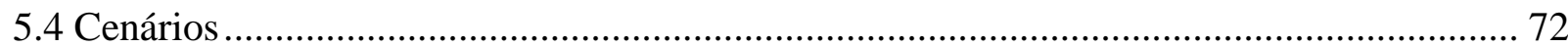

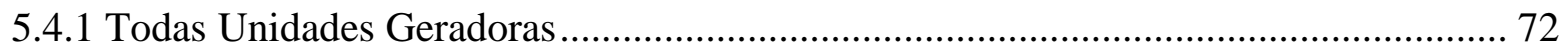

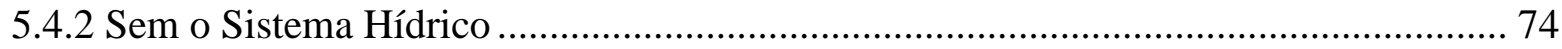

5.4.3 Célula a Combustível x Gerador Eólico ...................................................................... 75

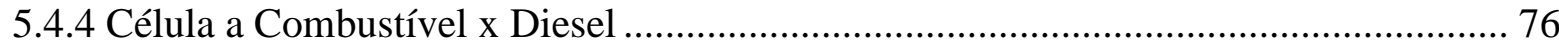

5.4.5 Célula a Combustível x Diesel com baixa velocidade de vento.................................. 78

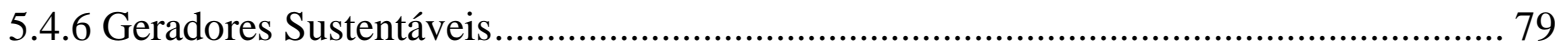

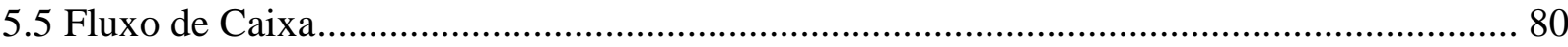

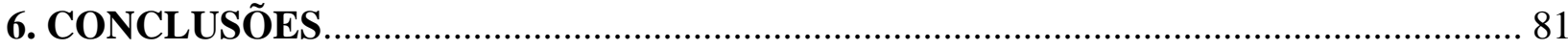

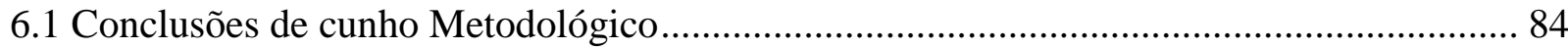

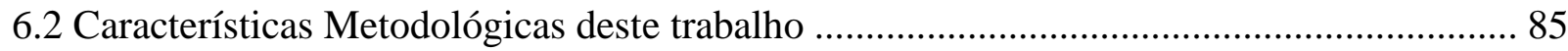

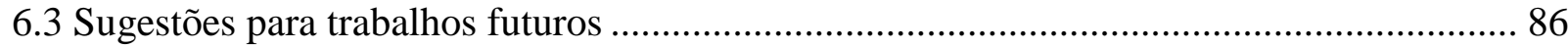

APÊNDICE A - Tarifas - Principais Concessionárias ............................................................. 87

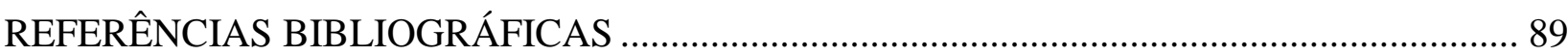




\section{LISTA DE FIGURAS}

FIGURA 01 - Representação do Sistema Híbrido para geração de eletricidade 68

\section{LISTA DE GRÁFICOS}

GRÁFICO 01 - Consumo de combustíveis fósseis no mundo 21

GRÁFICO 02 - Crescimento da Demanda de Energia Elétrica no Brasil................................... 22

GRÁFICO 03 - Matriz Energética Brasileira em 2009 ............................................................... 24

GRÁFICO 04 - Matriz de Energia Elétrica no Brasil em 2009 ................................................ 25

GRÁFICO 05 - Emissão Total de CO2 no Ciclo de Vida na Geração Elétrica ........................... 26

GRÁFICO 06 - Mapa das potencialidades eólicas do Brasil ..................................................... 32

GRÁFICO 07 - Mapa radiação solar global diária - média anual típica ..................................... 37

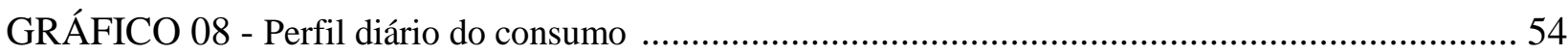

GRÁFICO 09 - Mapa de distribuição de carga ao longo do ano .............................................. 55

GRÁFICO 10 - Média de velocidade de vento em São Paulo .................................................. 59

GRÁFICO 11 - Média da radiação solar em São Paulo ............................................................. 60

GRÁFICO 12 - Caracterização da potência por velocidade de vento do Gerador Eólico ............. 62

GRÁFICO 13 - Valor Presente Líquido por tipo por sistemas .................................................. 69

GRÁFICO 14 - Comparação de custo entre o Gerador Hídrico e o de ampliação da rede .......... 71

GRÁFICO 15 - Comparação de custo entre o Sistema híbrido 'Hídrico/BB' e o da rede ........... 72

GRÁFICO 16 - Cenário 1: Todas Unidades Geradoras ................................................................ 73

GRÁFICO 17 - Cenário 2: Sem o Sistema Hídrico .................................................................. 75

GRÁFICO 18 - Cenário 3: Célula a Combustível x Eólico ......................................................... 76

GRÁFICO 19 - Cenário 4: Célula Combustível x diesel ........................................................... 77

GRÁFICO 20 - Cenário 5: CC x Diesel com baixa velocidade de vento .................................... 78

GRÁFICO 21 - Cenário 6: Geradores Sustentáveis ................................................................. 79

GRÁFICO 22 - Fluxo de Caixa Nominal Resumido do Gerador Hídrico ................................... 80 


\section{LISTA DE QUADROS}

QUADRO 01 - Tecnologia de geração mais comum, por Faixa de Potência .............................. 29

QUADRO 02 - Gerador: Célula a Combustível ....................................................................... 30

QUADRO 03 - Tipos de Célula a Combustível e suas aplicações ............................................ 36

QUADRO 04 - Visão Geral das Células a Combustível .......................................................... 31

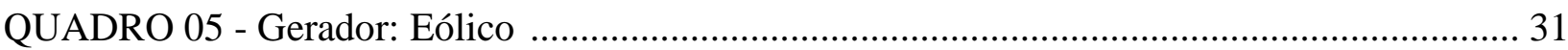

QUADRO 06 - Classificação por potência dos geradores eólicos .............................................. 33

QUADRO 07 - Visão Geral dos Geradores Eólicos..................................................................... 33

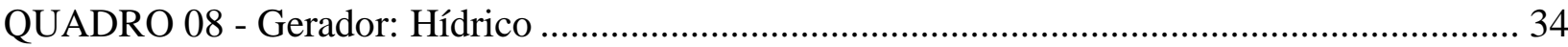

QUADRO 09 - Classificação por potência e queda d’água para geradores hídricos .................... 35

QUADRO 10 - Visão Geral dos Geradores Hídricos ................................................................ 35

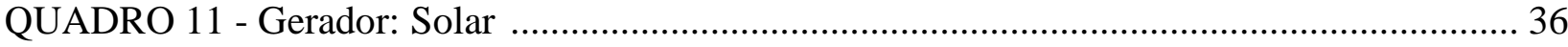

QUADRO 12 - Visão Geral dos Geradores Solares Fotovoltaicos ........................................... 37

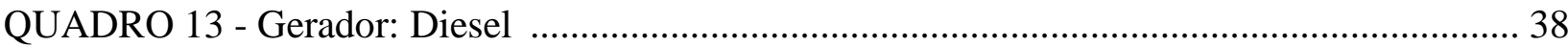

QUADRO 14 - Visão Geral do Grupo Moto Gerador.................................................................. 38

QUADRO 15 - Lista de Vantagens da Geração Distribuída .................................................... 41

QUADRO 16 - Tarifas Residenciais Vigentes até 2008 - Principais Concessionárias ............... 57

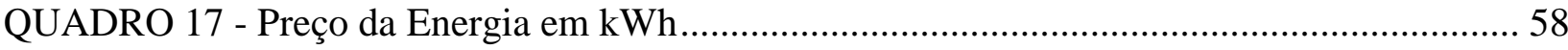

QUADRO 18 - Resumo dos valores para os custos de instalação e de manutenção .................... 66 


\section{LISTA DE ABREVIATURAS E SIGLAS}

AC - Corrente alternada

AFC - Célula a Combustível Alcalina

ANEEL - Agência Nacional de Energia Elétrica

ASME - American Society of Mechanical Engineers

BB - Banco de Baterias

CC - Célula a Combustível

CCCH - Centro de Célula a Combustível e Hidrogênio

CEMIG - Companhia Energética de Minas Gerais

CMMAD - Comissão Mundial sobre o Meio Ambiente e Desenvolvimento

CO - Monóxido de Carbono

$\mathrm{CO}_{2}$ - Gás Carbônico

COE - Cost of Energy - Custo da Energia

COGEN - Associação da Indústria de Cogeração de Energia

COP3 - Terceira Conferência das Nações Unidas sobre Mudanças Climáticas

DS - Desenvolvimento Sustentável

DC - Corrente Contínua

DMFC - Célula a Combustível de Metanol Direto

DOE - United States Departament of Energy

EPE - Empresa de Pesquisa Energética

GEE - Gases do Efeito Estufa

GD - Geração Distribuída

GLP - Gás Liquefeito de Petróleo

GMG - Grupo Moto Gerador

GWh - Gigawatts-hora

HOMER - Hybrid Optimization Model for Eletric Renewables

INEE - Instituto Nacional de Eficiência Energética

IPCC - Painel Intergovernamental para Mudança Climática

IPEN - Instituto de Pesquisas Energéticas e Nucleares

kW - Quilo watts

MCFC - Célula a Combustível de Carbonato Fundido

MCH - Mini Central Hidrelétrica 
MME - Ministério de Minas e Energia

Mw - Mega watts

Nox - Óxido nitroso

NREL - National Renewable Energy Laboratory

OIE - Oferta Interna de Energia

ONS - Operador Nacional do Sistema Elétrico

ONU - Organização das Nações Unidas

OST - Optimal System Type - Tipo de Sistema Ideal

PAFC - Célula a Combustível de Ácido Fosfórico

PCH - Pequena Central Hidrelétrica

PEMFC - Célula a Combustível de Membrana Protônica

PNE - Plano Nacional de Energia

PPA - Power Purchase Agreement

RETs - Energias renováveis e tecnologias energeticamente eficientes

RETScreen - Clean Energy Project Analisys Software

SOFC - Célula a Combustível de Óxido Sólido

UGEE - Unidades Geradoras de Energia Elétrica

TIR - Taxa Interna de Retorno

TEP - Tonelada Equivalente de Petróleo

UGEE - Unidades Geradoras de Energia Elétrica

TMA - Taxa Mínima de Atratividade

VPL - Valor Presente Líquido

$\mathrm{W} / \mathrm{m}^{2}-\mathrm{W}$ atts por metro quadrado

$\mathrm{W} / \mathrm{m}^{2} / \mathrm{d}$ - Watts por metro quadrado ao dia 


\section{INTRODUÇÃO}

A necessidade contínua de energia elétrica alterou a humanidade, determinando a sua dependência por este recurso para diversas atividades.

Asseguradas por fontes de energia cujo fornecimento depende de vários meios de geração elétrica, sistemas de distribuição, redes, conexões e fios elétricos, grande parte da produção de energia faz parte de um modelo derivado de geradores poluentes, o que leva os pesquisadores da área a importantes debates com a finalidade de encontrar alternativas menos agressivas ao meio ambiente, em busca do chamado Desenvolvimento Sustentável.

Tendo em vista mitigar os efeitos da atividade humana sobre o clima, a preocupação com o meio ambiente e acelerar o desenvolvimento humano, os países das Nações Unidas (ONU) assinaram um acordo que visou o controle sobre as intervenções humanas na atmosfera. Assim nasceram as ações propostas no Protocolo de Kyoto, realizado em 1997, durante a Terceira Conferência das Nações Unidas sobre Mudanças Climáticas (COP3) realizada na cidade de Kyoto, Japão. Este acordo deu ênfase à utilização de mecanismos de mercado que promovessem o financiamento de projetos mais limpos a nível mundial (UNFCCC, 2010a; UNFCCC, 2010b; LECOCQ e AMBROSI, 2007).

Como resultado, no Brasil desencadearam-se reflexões nas quais se estabeleceram novos desafios para o setor energético. Entre elas estão manter o foco no uso de tecnologias limpas, promover a universalização do fornecimento energético e reduzir os riscos ligados aos fenômenos climáticos adversos, utilizando eficientemente os recursos disponíveis (CHESF, 2011).

É neste ponto que o presente trabalho pretende contribuir, analisando de forma técnica e econômica diferentes unidades de geração elétrica, tema hoje vinculado às práticas de emissão de carbono, ao planejamento da utilização de recursos naturais e aos custos associados. Aborda-se o processo de decisão da melhor tecnologia de geração de energia elétrica para se adotar, tendo em vista um conjunto de opções hoje disponíveis comercialmente. 
Para isto a pesquisa contempla uma abordagem técnica e econômica de diferentes unidades de geração elétrica. São elas: célula a combustível movida a hidrogênio, geração eólica, hídrica, solar, e grupo motor gerador.

Inicialmente são apresentadas as principais tendências de uso da energia, os principais conceitos funcionais sobre energia limpa, seu atual estado de desenvolvimento tecnológico e o contexto onde será aplicado.

Não havendo um modelo real disponível para avaliação, recorreu-se ao software Hybrid Optimization Model for Electric Renewables (HOMER), para simular o funcionamento das unidades geradoras. Para o desenvolvimento deste modelo, utilizouse do conceito de várias fontes de energia dentro do mesmo sistema fornecedor, conhecido como sistema híbrido.

Para se determinar quais unidades geradoras deveriam ser utilizadas, ou em que medida isto pode ser feito, numa perspectiva econômica são utilizados os métodos quantitativos como o Valor Presente Líquido (VPL), Custo da Energia (COE), e Ponto de Equilíbrio da Rede (PER).

Assim, este trabalho propõe-se a discutir o tema energético, simular um modelo de sistema híbrido, isolar os que atendem tecnicamente, selecionar os de menor custo, analisar sua variáveis de sensibilidade, e discutir os resultados sob um foco técnico e econômico.

Para melhor entendimento e facilidade de assimilação, a sequência deste trabalho foi dividida em cinco capítulos: objetivo, revisão da literatura, metodologia, resultados e conclusão. 


\section{OBJETIVO}

O objetivo deste estudo é analisar a viabilidade técnica e econômica de sistemas híbridos de energia distribuída, que forneçam uma potência estabelecida em 250 kW, compostos por diferentes unidades geradoras: célula a combustível movida a hidrogênio, eólica, hídrica, solar, gerador a diesel.

\section{REVISÃO DA LITERATURA}

A revisão de literatura aborda em sua primeira parte os autores e publicações que mais contribuíram para o aprimoramento deste trabalho. Efetuou-se uma pesquisa bibliográfica em bases de dados especializadas com o intuito de aprofundar os conhecimentos disponíveis nos trabalhos da área, buscando alcançar o estado da arte deste campo de pesquisa.

A análise desta literatura permitiu realizar comparações entre o tema escolhido e os trabalhos anteriores, proporcionando a oportunidade de situar-se o campo da pesquisa, além de servir de suporte aos resultados obtidos. Foram identificados conteúdos que se referem principalmente a análises de sistemas que se utilizaram do software HOMER, estudos de viabilidade vinculados à área energética e trabalhos sobre energias sustentáveis.

Dos trabalhos que se utilizam do software HOMER, com temáticas e estruturas semelhantes a este trabalho, destacam-se os de: Demiroren e Yilmaz (2009), onde foi estudado o custo da energia elétrica usando energias renováveis; Siqueira et al. (2010), que aborda as fontes de energias alternativas para implementação em um prédio; Almeida e Freire (2008), que discutem a geração híbrida para um hospital e o de Henriques Jr. e Szklo (2008), que analisa a implantação de unidades geradoras em comunidades rurais. 
Outras publicações que se utilizaram do software HOMER em suas análises que trouxeram contribuição a esta pesquisa foram: Levene et al. (2006) que também busca um resultado econômico; Al-Karaghouli e Kazmerski (2010), em sua abordagem a respeito das características técnicas e econômicas, obtém uma análise sobre o custo da energia e a de Kanase-patil et al. (2009) que contribui com uma importante análise da sensibilidade do custo de combustíveis de biomassa.

No campo das simulações ainda destacam-se as publicações: HOMER (2011); NREL (2005); Almeida Filho (2006) e Albuquerque et al., (2009).

Na área de administração financeira ressalta-se o trabalho de Ross et al. (2008), e o de Van Den Wall Bake et al. (2009), que chegam a importantes conclusões sobre a diminuição de custos na área energética ao longo do tempo. Ainda dentro do campo econômico, Braga et al. (2009) debatem a viabilidade econômica da integração de células a combustível e Nishi et al., (2005) colaboram dando enfoque ao tema viabilidade econômica e as ferramentas de análise financeiras dentro de um trabalho na área ambiental. Citam-se ainda na área de custos os trabalhos de Rosado Jr. et al. (2009) em sua análise sobre uma microdestilaria; Vinha e Verissimo (2006) com a análise de Payback e Marinosk e Ghisi (2008) com suas análises sobre o custo de implantação de um projeto.

Em Hinrichs e Kleinbach (2003), é abordado o tema energético e o meio ambiente em profundidade. Farret e Simões (2006) e Pinho et al. (2008), abordam as energias sustentáveis e os sistemas híbridos.

O livro de Rifkin (2003), as informações do Centro de Gestão e Estudos Estratégicos (CGEE, 2008), a dissertação de Conejero (2006) e a tese de Lourenço (2006) geram uma importante fonte para discussões a respeito da inserção e amadurecimento do uso das energias na economia.

EPE (2011a; 2011b) e Senna e Castro (2009) abordam detalhes técnicos relativos à área de elétrica e seus sistemas. No que tange à Geração Distribuída (GD), os trabalhos de Ackermann et al. (2001), Dias et al. (2005), Moreira et al. (2004) e da COGEN (2010), trazem valiosas informações, além do livro de Lora e Haddad (2006) que trata das unidades geradoras em uso dentro do campo da GD. 
Na área de células a combustível e hidrogênio este trabalho foi influenciado por diferentes estudos que explicam os aspectos peculiares deste mercado, além de temática técnica (LINARDI, 2010a; LINARDI, 2010b; NRC e NAE, 2004).

No âmbito metodológico utilizou-se da experiência encontrada nos trabalhos desenvolvidos por Igami e Zarpelon (2002); Mendonça (2003); ABNT - NBR 14724 (2001); NBR 10520 (2001); NBR 6023 (2000) além de Silva e Menezes (2005).

As revistas mais relevantes para esta pesquisa foram Renewable Energy, Renewable and Sustainable Energy Reviews, Electric Power Systems Research, Energy Police.

Ressalta-se que apesar da similaridade com outros trabalhos em alguns aspectos, não se encontrou na literatura trabalho análogo contendo todos os elementos deste estudo.

\section{1 - Energia}

Os tópicos ligados ao tema energético procuraram contextualizar e levantar conhecimentos importantes para a execução desta análise. Para tanto trata do uso e das tendências na sua utilização, de conceitos na área de energia, dos tipos de usinas utilizados, da geração distribuída, de aspectos da modelagem e dos métodos quantitativos.

O filme Guerra do Fogo (La Guerre du Feu), de 1981, dirigido pelo francês Jean-Jacques Annaud e consagrado por um Oscar, narra uma história que se passa nos primórdios da humanidade. Dois grupos de hominídeos concorrem por território e recursos, em uma disputa decidida pela habilidade de se produzir e controlar o fogo. Há 125 mil anos o ser humano passou a ter o controle generalizado deste tipo de energia (NICHOLSON, 1996), essencial para protegê-lo do frio, dos predadores, de insetos, para cozinhar alimentos e garantir sua segurança em meio à escuridão. Tal capacidade viria a contribuir para a colonização do planeta. 
Em tempos mais recentes, o advento da eletricidade alterou costumes, cultura e sociedades, determinando nossa dependência por este recurso. Assim, produzir e consumir energia são atividades no mundo de hoje tão ameaçadoras ao ecossistema quanto vitais à sociedade moderna.

Estudos ao redor do mundo apontam que as fontes fósseis como o petróleo ou o carvão mineral são nocivas ao meio ambiente. O relativo consenso no mundo acadêmico que se compôs em torno da mais importante causa do aquecimento global, a emissão de gases do efeito estufa na atmosfera, converteu em vilã quase toda geração de energia. Até mesmo a geração hídrica, não ligada à emissão direta de carbono à atmosfera, pode ter grande influência na natureza em suas etapas de implantação e operação.

A necessidade de consumo de energia pela humanidade é contínua e crescente. Grande parte da sua produção acarretará danos à vida terrestre enquanto perdurar o modelo derivado de energias fósseis. Ainda assim, a energia é um dos insumos básicos para o desenvolvimento econômico e social, portanto, tem um papel importante na questão ambiental e no desenvolvimento sustentável. Por isto cabe ao próprio homem atuar positivamente através de ações mitigadoras.

As formas de produção de energia ganharam ainda mais espaço nos meios de comunicação após o terremoto e tsunami no Japão, em 2011. O acidente na usina nuclear de Fukushima gerou um maior debate sobre as matrizes energéticas, influenciando inclusive resultados de eleições, como na Alemanha. Do ponto de vista de grande parte da Europa, a tragédia japonesa fortaleceu a discussão sobre o uso das energias sustentáveis, vista pela população como de menor prejuízo à natureza e à saúde (SIMÕES, 2011; TERREMOTO, 2011).

Apesar do progresso na forma de lidar com o problema energético e ambiental, ainda é preciso avançar muito neste sentido. É necessário instituir novos modelos de desenvolvimento sustentável no mundo, em que se estabeleçam alternativas de utilização dos recursos e de novas formas de gestão e de tecnologias, orientadas por uma racionalidade social e ambiental. 


\subsection{1 - Uso e tendências}

Água, vento, biomassa, gás natural, urânio, carvão mineral e petróleo, compõem algumas das opções de fontes para fornecimento de energia. Parte desses recursos é finita, poluente e possui demanda cada vez maior. Portanto, continua sendo necessária a busca por alternativas que visem diminuir os impactos da limitação de recursos e dos danos ambientais.

Segundo Hinricks e Kleinback (2003), entender a utilização da energia também significa perceber as conseqüências ambientais do seu uso. Um dos pontos importantes está relacionado à queima de combustíveis fósseis. A possibilidade de mudanças climáticas globais originadas pelos crescentes níveis de gases do efeito estufa aumenta com seu emprego. Bilhões de toneladas de carbono são anualmente acrescentados à nossa atmosfera pela combustão destes combustíveis. A temperatura média global aumentou aproximadamente $0,5^{\circ} \mathrm{C}$ desde 1900 . Temperaturas globais altas podem interferir na produção agrícola, mudar os padrões climáticos, elevar o nível do mar, causando prejuízos econômicos, ambientais e sociais.

Assim, na busca pela melhor gestão da cadeia de recursos naturais e ecossistemas - que envolve também a área energética - nasceu o conceito de Desenvolvimento Sustentável (DS), introduzido pela Comissão Mundial sobre Meio Ambiente e Desenvolvimento (CMMAD) em 1987, através do Relatório Brundtland, intitulado do mesmo modo de ‘Nosso Futuro Comum’ (UN, 1987; USDA, 2009).

O gráfico 01 (MORIARTY e HONNERY, 2008; BP 2010) ilustra o uso de combustíveis fósseis no mundo e seu respectivo crescimento em números absolutos de 1970 até 2009. Pode-se observar que o consumo vem se elevando a cada década, o que reforça a preocupação com as conseqüências da adoção de combustíveis fósseis na geração de energia. 


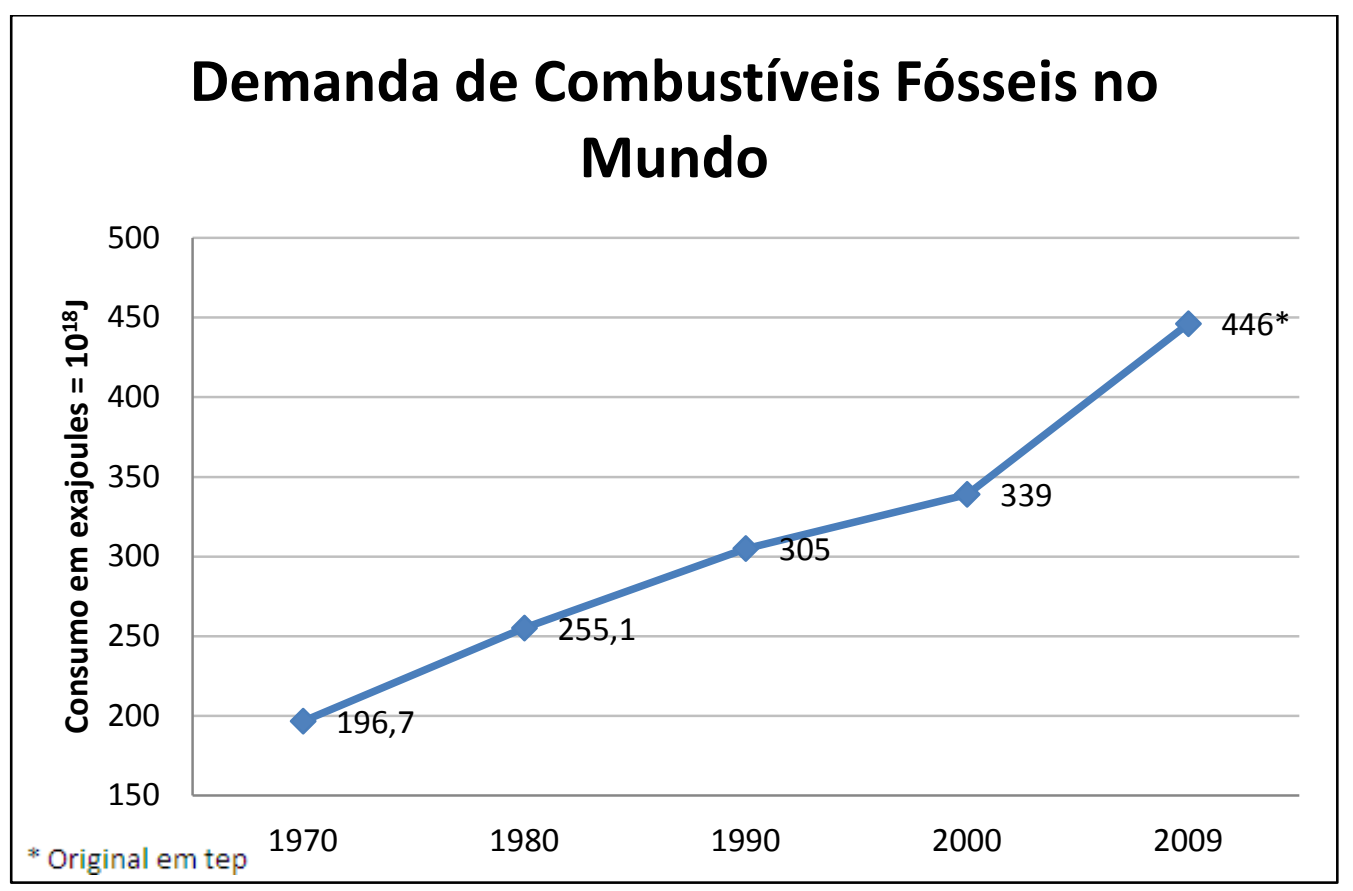

GRÁFICO 01 - Consumo de combustíveis fósseis no Mundo

Moriarty e Honnery,2008; BP, 2010

Segundo a Empresa de Pesquisa Energética (EPE 2011a) o Plano Nacional de Energia, o PNE 2030, produzido em 2007, é a principal publicação existente no país referente ao planejamento energético de longo prazo. Este documento preserva a sua atualidade e continua norteando diferentes projetos, estabelecendo-se como referência obrigatória para os trabalhos desenvolvidos nesta área. Por este motivo, os dados que fazem parte do escopo energético contidos neste estudo, respeitam este plano.

A demanda por eletricidade no Brasil e no mundo vem crescendo continuamente. No Brasil, ao longo da década, deverá crescer a uma taxa média próxima de 5\% ao ano. Estima-se que, do total de 456,5 mil gigawatts-hora (GWh), no ano de 2010, chegue-se a 730,1 mil GWh em 2020, aumentando em cerca de 60\% o consumo. Considerando o intervalo em questão, a ampliação de 274 mil GWh representa um volume superior ao atual consumo de eletricidade do México e está próximo ao presente consumo de eletricidade da Espanha (EPE, 2011a, EPE, 2011b).

As projeções sugerem que uma importante parcela da demanda total de eletricidade do país será atendida por autoprodução, por indústrias que usam resíduos do 
processo produtivo como combustível, como é o caso dos segmentos de siderurgia, papel e celulose, petroquímica e indústria sucroalcooleira, principalmente.

Este é um dado importante, já que a autoprodução faz parte do escopo da geração distribuída contida neste trabalho. As previsões para auto-geração apontam para um crescimento de 6,6\% ao ano e deverá atingir 71 mil GWh em 2020 - o equivalente a $10 \%$ do consumo total de eletricidade de 2011. Isso corresponde a um acréscimo previsto, ao final de 10 anos, de cerca de 34 mil GWh (EPE, 2011a, EPE, 2011b).

O crescimento da demanda de energia elétrica no Brasil pode ser visualizado no gráfico 02 (PORTELA 2010 apud ONS $^{1}$, 2010). Observa-se, pelo gráfico, que a expansão vem aumentando ano a ano. Os valores referem-se sempre ao pico de consumo na primeira quinta-feira de fevereiro, dos anos de 2002 até 2010:

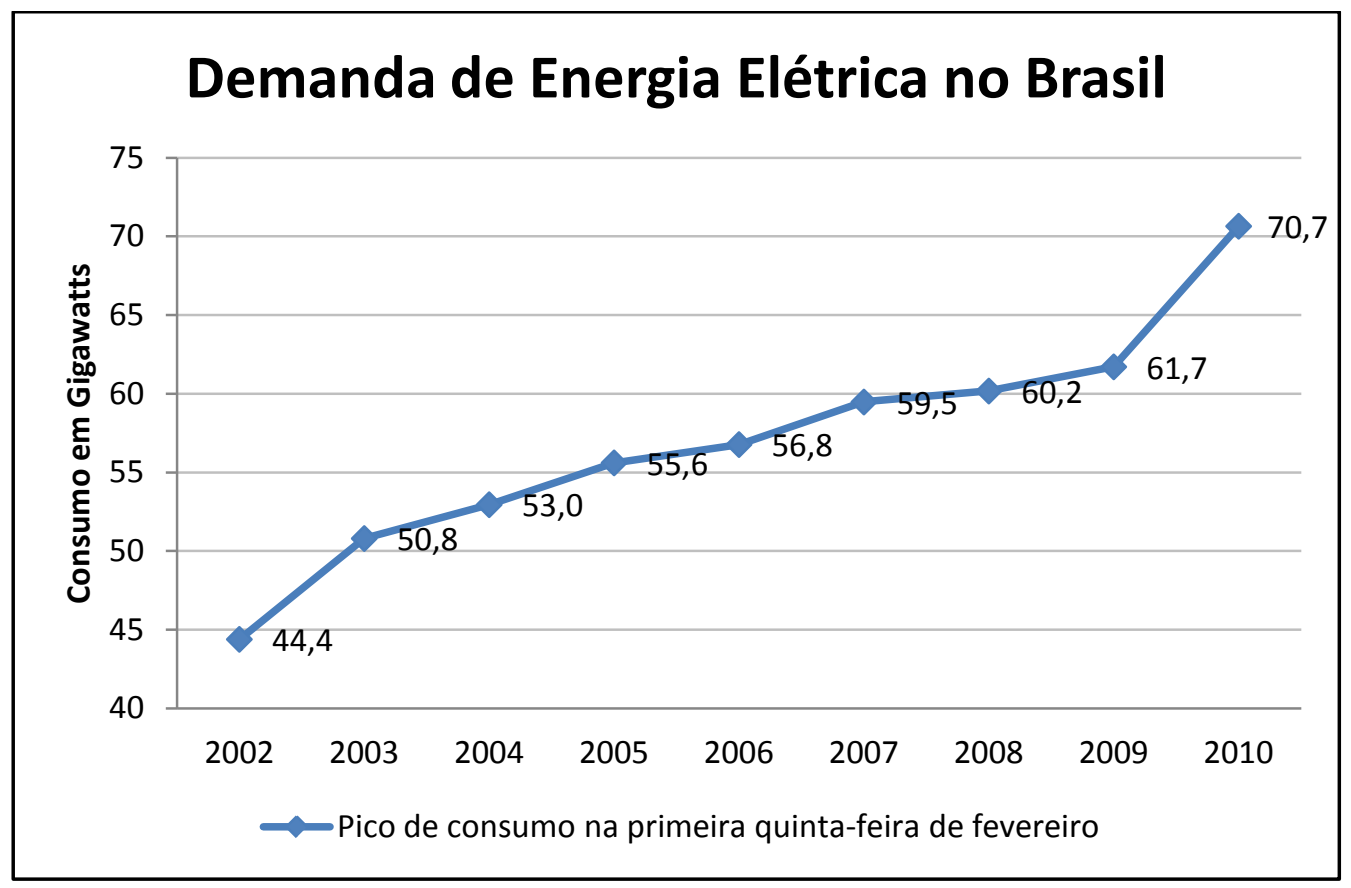

GRÁFICO 02 - Crescimento da Demanda de Energia Elétrica no Brasil Portela, 2010 apud ONS, 2010

\footnotetext{
${ }^{1}$ Operador Nacional do Sistema
} 
Visando atender a esta demanda crescente, deve-se escolher o tipo de geração de energia a ser utilizada. O Painel Intergovernamental para Mudança Climática (IPCC) publicou um relatório sobre o uso de energias renováveis no mundo, que corresponde hoje a aproximadamente $13 \%$ da energia total utilizada. Desconsiderando-se a utilização da energia da biomassa e das hidrelétricas, do total das renováveis, o percentual cai para cerca de $0,5 \%$. Além disto, segundo o relatório, a parcela correspondente às energias mais frequentemente associadas à redução das emissões de gases que provocam o efeito estufa (GEE) ainda é pequena, mas vem crescendo ao longo do tempo. A geração de energia eólica cresceu acima de $30 \%$, a hídrica por volta de $3 \%$ e a solar acima de $50 \%$ no ano de 2009. O documento do IPCC diz que na maioria dos mais de 160 cenários científicos analisados, as energias renováveis serão mais eficientes do que a nuclear para reduzir emissões até 2050 (CAMARA, 2011; IPCC, 2011).

As energias renováveis, em maior parte as que se utilizam de recursos do vento e do sol, responderam por aproximadamente metade do crescimento da produção de energia global em 2009. Na Alemanha e na China, as energias sustentáveis vêm avançando, fruto dos incentivos do governo. Na Alemanha esta proporção atinge 17\% do total e a China, um dos principais países responsáveis pela expansão da produção de energia renovável nos últimos anos, mais do que duplicou a sua capacidade eólica desde 2008. Na Espanha, os parques eólicos cobrem 21\% da demanda, e as energias renováveis forneceram $42,2 \%$ da eletricidade consumida pelos espanhóis em março de 2011 (CAMARA 2011; EXAME apud AFP, 2011).

No Brasil, o volume de renováveis atingiu, em 2009, 47,2\% do total da oferta interna de energia. De fato, do ano de 2000 até 2009 houve um avanço de 51\% no total de energia disponível derivado destas fontes. Com 243,7 milhões tep ${ }^{2}$, nosso país produz 2\% da energia mundial e possui uma média de uso das renováveis muito superiores à média mundial, que hoje é de $12,7 \%$. Os produtos provenientes da cana contribuem com 18\%, da lenha e carvão vegetal com 10,1\% e outras fontes como a geração eólica, biodiesel, solar e o uso de lixívia ${ }^{3}$ na produção de celulose completam o escopo referente às outras fontes renováveis (MME, 2008; MME, 2009; MME, 2010).

\footnotetext{
${ }^{2}$ Tonelada de equivalente de petróleo

${ }^{3}$ Hipoclorito de sódio
} 
É comum nos balanços energéticos que a soma do consumo final de energia, das perdas na distribuição e armazenagem e das perdas nos processos de transformação, recebam a denominação de Oferta Interna de Energia (OIE), também chamada de demanda total de energia. A estrutura da OIE por energético é comumente chamada de Matriz Energética. No gráfico 03 (MME, 2010) pode-se observar a OIE no Brasil em 2009.

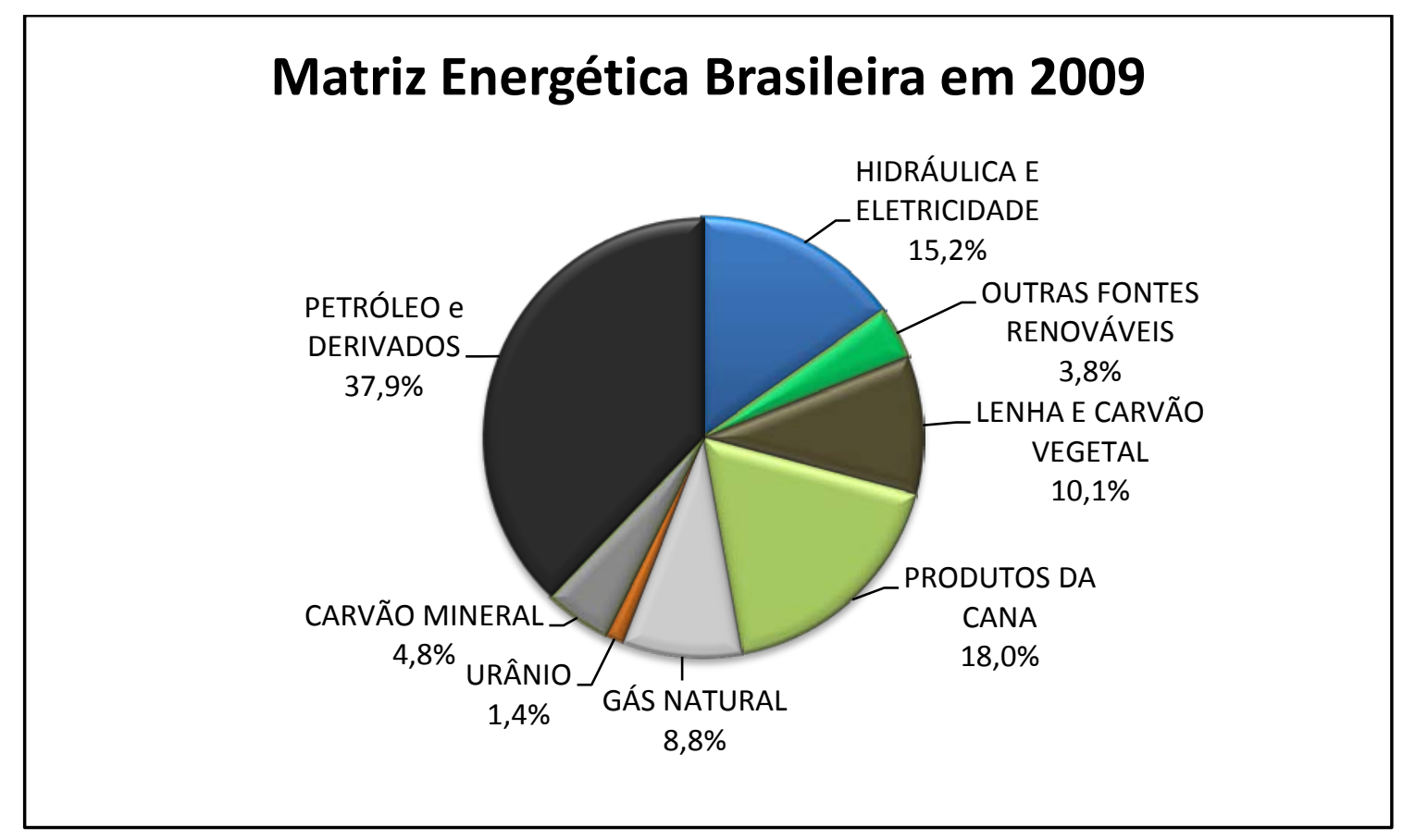

GRÁFICO 03 - Matriz Energética Brasileira em 2009

MME, 2010

Com relação à oferta somente de energia elétrica, no ano de 2009 houve um aumento da geração hídrica e redução da geração térmica ${ }^{4}$, resultando em uma maior passagem de cargas entre as usinas e os locais de consumo o que, por sua vez, acarretou maiores perdas relativas na transmissão. Este dado aumenta a importância de se desenvolver a geração distribuída. A fonte hídrica representa aproximadamente $77 \%$ da energia elétrica produzida no Brasil, sendo esta sua principal fonte. No gráfico 04 (MME, 2010) ilustra-se a matriz de energia elétrica brasileira:

\footnotetext{
${ }^{4}$ A geração térmica procura ser instalada próximo ao centro de carga.
} 


\section{Matriz de Energia Elétrica no Brasil em 2009}

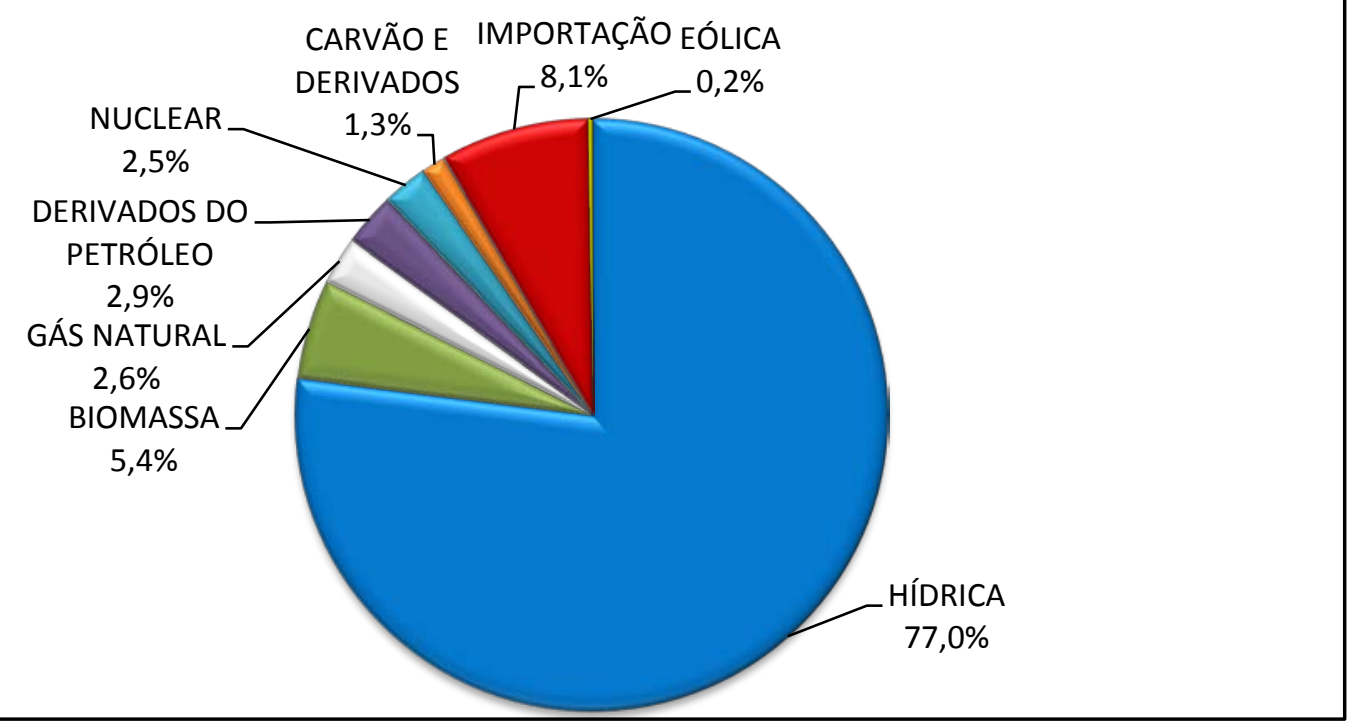

GRÁFICO 04 - Matriz de Energia Elétrica no Brasil em 2009

MME, 2010

As pesquisas elaboradas mundialmente, para promover a redução da taxa de crescimento dos GEE na atmosfera, têm indicado para um conjunto de ações de curto, médio e longo prazo. Neste conjunto levam-se em conta a substituição de combustíveis fósseis, a adoção de medidas que tornam mais eficiente o uso da energia, criação de medidas legislativas de contenção de emissões, investimentos no desenvolvimento das fontes renováveis de energia, produção de combustíveis derivados da biomassa ou o uso do hidrogênio (SILVA et al. 2003).

A comercialização de créditos de carbono associados a projetos de auto-geração e co-geração, por exemplo, colabora oferecendo um diferencial para os compradores, tornando-os mais atrativos comercialmente e abrindo a possibilidade de avanços mais rápidos nas tecnologias a eles associadas (SANTOS, 2011).

Muito se discute sobre a emissão total de $\mathrm{CO}_{2}$ provocada por cada tipo de gerador elétrico. Essas emissões não se restringem somente à operação, pois é preciso levar em consideração a fabricação dos componentes, a implantação e o 
descomissionamento ${ }^{5}$ dos geradores. Nos dados levantados por Sovacool (2008) podese observar que a emissão total de $\mathrm{CO}_{2}$ no ciclo de vida das energias renováveis é muito mais baixa, quando comparada às emitidas pelos geradores fósseis. Este fato faz com que haja empenho nas comunidades ambientais para implementação das primeiras no cenário mundial. No gráfico 05 pode-se observar uma síntese dessas emissões.

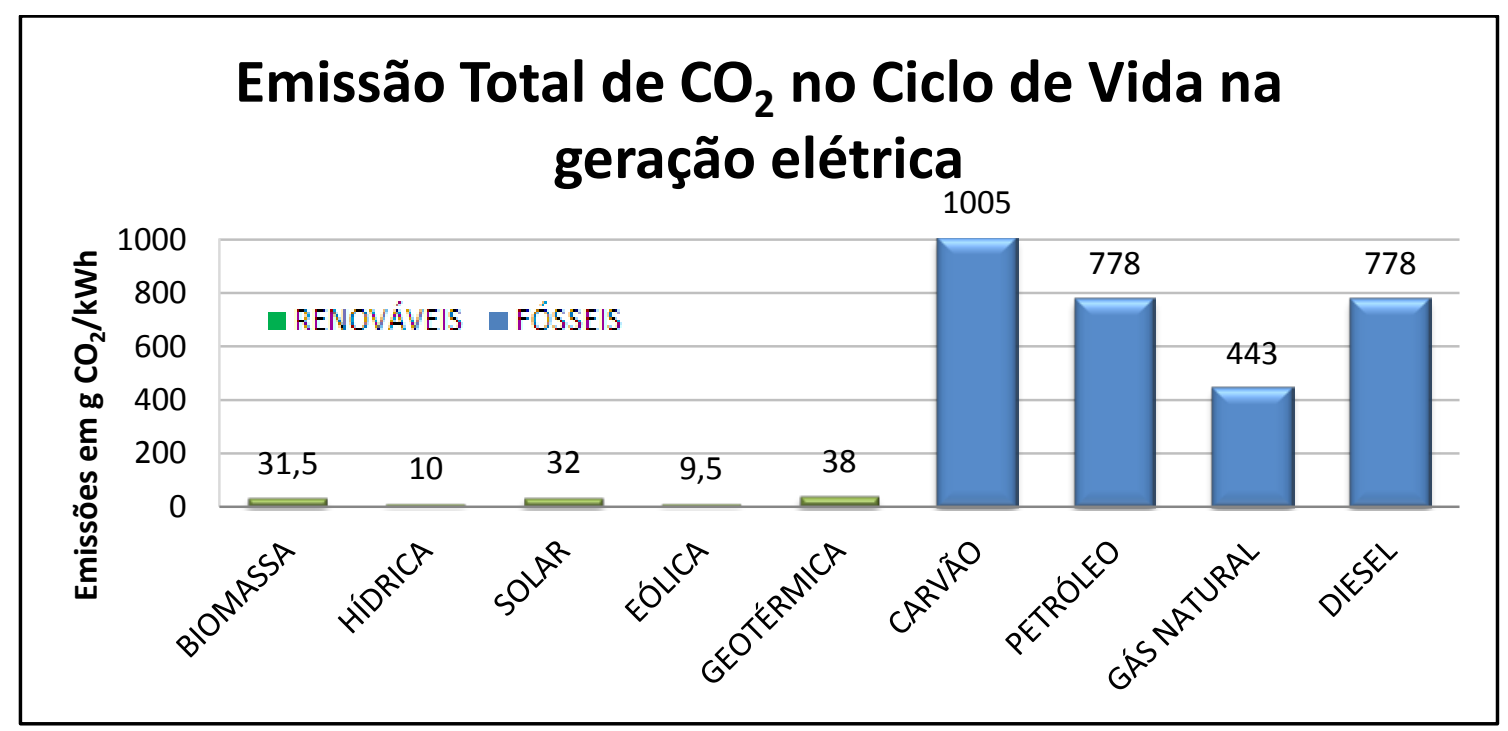

GRÁFICO 05 - Emissão Total de $\mathrm{CO}_{2}$ no Ciclo de Vida na Geração Elétrica Sovacool, 2008

Assim, a comunidade científica vem propondo que a substituição das energias fósseis se intensifique, de forma que a transição para um novo perfil de consumo de energia, com menor emissão de gases nocivos, ocorra sem as instabilidades que poderiam advir de uma escassez das não-renováveis.

Apesar de não serem isentas de problemas, como ocorre com todas as atividades humanas, em maior ou menor grau, as fontes sustentáveis de energia surgem hoje como uma das melhores opções para que se atendam os direcionamentos introduzidos pela CMMAD para o Desenvolvimento Sustentável.

\footnotetext{
5 Descomissionamento é o processo de desinstalação, desativação ou encerramento de atividades poluidoras ou que atuem no processamento, armazenamento e circulação de substâncias nocivas à Saúde Pública ou ao Meio Ambiente.
} 


\subsection{2 - Fontes de Energia}

As fontes de energia podem ser classificadas em fontes primárias e secundárias. As fontes primárias, também conhecidas como fonte de energia natural, geram energia de forma direta. Temos como exemplo o petróleo, carvão mineral, fissão nuclear e também energia gravitacional, associada ou não ao movimento dos corpos e fluidos. Já fontes de energias secundárias são derivadas a partir das fontes de energia primárias como, por exemplo, a energia elétrica, gasolina, diesel, alcatrão, vapor, etc.

As fontes de energia também podem classificar-se em renováveis e não renováveis. Dentre as renováveis, assim denominadas por serem geradas por fontes consideradas infinitas, mesmo que extensivamente utilizadas pelo homem tem-se, por exemplo, a energia solar, hídrica, eólica, oceânicas, energia geotérmica ou mesmo a da biomassa, que é capaz de produzir energia em processos de transformação por combustão ou outros processos químicos. Nas fontes de energias não renováveis destacam-se o combustível fóssil, originário de restos biológicos que demoraram milhões de anos até se transformarem em combustível, ou as fontes do subsolo, como o urânio. Estas não podem ser recuperadas e suas quantidades tornam-se cada vez mais reduzidas pelo consumo.

Os sistemas renováveis podem apresentar problemas quanto à inconstância da fonte e a variação no regime de vento, de chuvas e outros eventos climáticos, como El Niño, que atrapalham a produção de energia. Mas apresentam a vantagem de não fazerem uso de matéria prima não renovável, cujos preços tendem a aumentar a longo prazo pela lei da oferta e demanda.

Cabe ainda, para melhor entendimento, definir Energia Sustentável e Energia Limpa. Energia Sustentável é a que mantém um ciclo equilibrado de produção e consumo, porque é gasta numa quantidade e em uma velocidade na qual a natureza pode repô-la. O conceito está diretamente ligado ao de Desenvolvimento Sustentável de atender às necessidades do presente sem comprometer a capacidade das gerações futuras satisfazerem as suas necessidades. Levam-se em conta os fatores ambientais, mas não significa fundamentalmente que seja energia limpa. A lenha, por exemplo, é um recurso sustentável quando é cultivada para esse fim, mas a fumaça de sua queima é 
tóxica e poluente e, portanto, não é limpa. Várias fontes de energia podem ser ou não sustentáveis. A água é sustentável desde que seus mananciais e o fluxo sejam preservados, o que implica em proteger as matas e evitar que um rio ou uma represa percam volume. Normalmente, o conceito de energia sustentável também inclui tecnologias que melhorem a eficiência energética.

Energia Limpa é aquela que não polui, ou em uma definição mais precisa a que polui menos que as convencionais. Entre os exemplos temos a célula a combustível, a dos ventos, hídrica, e solar. No Brasil, grandes represas hidrelétricas foram construídas, mas alguns projetos não consideraram a necessidade de retirar as matas antes do enchimento das represas. Debaixo da água, as árvores se decompõem liberando gases de efeito estufa por dezenas de anos, como ocorre nas represas de Itaipu ou Tucuruí. O conceito também pode ser aplicado na comparação entre produtos como os automóveis movidos a hidrogênio, que são considerados mais limpos que os movidos à gasolina, pois são menos poluentes. Deve-se, então, na escolha do sistema, levar em consideração que adotar energias limpas geram menos custo ao meio ambiente, levando-se em conta a diminuição do passivo ambiental.

\section{2 - Unidades geradoras de energia elétrica}

Para a escolha das unidades geradoras de energia elétrica buscaram-se as tecnologias de geração que atendessem à faixa de potência de 250 kW. No quadro 01, diversas unidades de geração foram divididas em oito faixas de potências de acordo com a tecnologia utilizada. Neste quadro procura-se explicitar a tecnologia mais comum utilizada em cada faixa de potência dentro de uma fonte de recursos, já que nem todas as tecnologias atendem ao total das faixas de potência, segundo estudo de Udaeta et al. (2009). A coluna deste estudo concentrou-se entre $100 \mathrm{~kW}$ a $500 \mathrm{~kW}$. Optou-se então pelo eólico, hídrico, solar fotovoltaico. Para a célula a combustível utilizou-se dos autores Ribeiro (2008); PER (2009); Eletrocell (2011) para a complementação do quadro. 
QUADRO 01 - Tecnologia de geração mais comum, por Faixa de Potência Udaeta et al,. 2009; Ribeiro, 2008; PER 2009; Electrocell 2011

\subsection{1 - Célula a Combustível}

A célula a combustível é um sistema eletroquímico que transforma energia química de um combustível, especialmente o hidrogênio, em eletricidade, calor e água, em uma alimentação contínua. A combinação do hidrogênio com o oxigênio presente no ar é um processo conhecido como eletrólise reversa. Sua eficiência energética é superior aos motores de combustão interna. Seu apelo ambiental está em diminuir, ou até mesmo não emitir, os gases que são normalmente liberados pelas máquinas térmicas convencionais (LINARDI, 2010b; SILVA et al. , 2003).

Atualmente, a maior parte do hidrogênio obtido mundialmente provém das fontes fósseis. Por meio da reforma do gás natural são produzidos aproximadamente 48\% do hidrogênio no mundo; o petróleo e o carvão são responsáveis por 30\% e 18\% da produção, respectivamente. Os 4\% restantes são devidos à eletrólise. O hidrogênio 
pode ser produzido por meio de fontes renováveis, como solar, hidráulica, eólica e a biomassa (SILVA et al. , 2003). No quadro 02 sintetizam-se algumas características do hidrogênio.

\begin{tabular}{|c|c|c|c|c|}
\hline Fonte & Obtenção & Usos & Vantagens & Desvantagens \\
\hline $\begin{array}{c}\text { Célula a } \\
\text { Combustível }\end{array}$ & $\begin{array}{c}\text { A forma mais } \\
\text { comum de obter o } \\
\text { hidrogênio } \\
\text { Industrial é por } \\
\text { reforma catalíca de } \\
\text { hidrocarbonetos }\end{array}$ & Geração de energia elétrica & $\begin{array}{c}\text { Não emite gases do efeito } \\
\text { estufa durante a operação. } \\
\text { Não precisa de turbinas ou } \\
\text { motores para produção de } \\
\text { energia elétrica. }\end{array}$ & Alto custo \\
\hline
\end{tabular}

QUADRO 02 - Gerador: Célula a Combustível.

A categorização em relação às células combustíveis mais comuns se refere ao tipo de eletrólito ${ }^{6}$ empregado na célula, destacando-se seis:

- AFC - Célula a Combustível Alcalina;

- PEMFC - Célula a Combustível de Membrana Protônica;

- PAFC - Célula a Combustível de Ácido Fosfórico;

- MCFC - Célula a Combustível de Carbonato Fundido;

- SOFC - Célula a Combustível de Óxido Sólido;

- DMFC - Célula a Combustível de Metanol Direto

Cada célula possui aplicações próprias, diversas temperaturas de operação e diferentes materiais para o eletrólito. No quadro 03 diferenciam-se os tipos de célula a combustível e suas aplicações:

\begin{tabular}{|c|l|l|l|l|}
\hline Tipo & \multicolumn{1}{|c|}{ Potência } & \multicolumn{1}{c|}{$\begin{array}{c}\text { Temperatura } \\
\left({ }^{\circ} \mathrm{C}\right)\end{array}$} & $\begin{array}{c}\text { Eficiência } \\
\text { Típica }(\%)\end{array}$ & \multicolumn{1}{|c|}{ Aplicação } \\
\hline AFC & $300 \mathrm{~W}$ a $5 \mathrm{~kW}$. & 50 a 200 & 55 a 60 & Veículos \\
PAFC & $<200 \mathrm{KW}$ & 150 a 210 & 42 a 47 & Geração Estacionária \\
\cline { 2 - 6 } PEMFC & 50 a $250 \mathrm{~kW}$ & 60 a 110 & 45 a 65 & Veículos/Geração Estacionária \\
\cline { 2 - 6 } DMFC & 50 a $250 \mathrm{KW}$ & 45 a 100 & 50 a 55 & Veículos \\
MCFC & $10 \mathrm{~kW}$ a $2 \mathrm{MW}$ & 630 a 650 & 55 a 60 & Geração Estacionária \\
SOFC & $<100 \mathrm{~kW}$ & 800 a 100 & 40 a 45 & Geração Estacionária \\
\hline
\end{tabular}

Quadro 03 - Tipos de Célula a Combustível e suas aplicações

Ribeiro, 2008, PER 2009, Electrocell 2011

\footnotetext{
${ }^{6}$ Eletrólito é toda a substância que, dissociada ou ionizada, origina íons positivos (cátions) e íons negativos (ânions), pela adição de um solvente ou aquecimento. Desta forma torna-se um condutor de eletricidade.
} 
No quadro 04 apresenta-se um quadro resumo de algumas características gerais das Células a Combustível considerando os eletrólitos AFC, PAFC, PEMFC, DMFC, MCFC, SOFC:

\begin{tabular}{ll}
\hline Disponível comercialmente & Sim \\
Faixa de capacidades & $1 \mathrm{~kW}$ a $2 \mathrm{MW}^{7}$ (uso modular) \\
Combustível & Hidrogênio \\
Eficiência & $32-65 \%{ }^{6}$ \\
Emissões de Poluentes & Pequena \\
Emissão total de $\mathrm{CO}_{2}\left(\mathrm{~g} / \mathrm{CO}_{2}\right)$ & $16^{8}$ \\
Outras características & Baixo nível de ruído, potencial para baixo custo de \\
& manutenção. \\
Custo do Investimento por kW & $7000-8000^{7,9}$ US $\$$ \\
Status comercial & Produto dependente de subsídios para ser competitivo. \\
\hline
\end{tabular}

Quadro 04 - Visão Geral das Células a Combustível

\subsection{2 - Geradores Eólicos}

A energia eólica é uma energia renovável considerada como uma das mais promissoras fontes naturais de energia e de baixo impacto ambiental. A Energia Eólica é a energia obtida pelo movimento do ar, pela força dos ventos.

Os geradores eólicos vêm melhorando gradualmente com relação ao nível de ruído. Também têm sido desenvolvidos sistemas servo-motores mais avançados, que vem aprimorando sua eficiência. No quadro 05 resumem-se algumas características da fonte eólica:

\begin{tabular}{|c|l|l|l|l|}
\hline Fonte & \multicolumn{1}{|c|}{ Obtenção } & \multicolumn{1}{|c|}{ Usos } & \multicolumn{1}{c|}{ Vantagens } & \multicolumn{1}{c|}{ Desvantagens } \\
\hline & $\begin{array}{l}\text { O movimento das } \\
\text { massas de ar é } \\
\text { captado por hélices }\end{array}$ & $\begin{array}{l}\text { Produção de energia elétrica. } \\
\text { Movimentação de moinhos. }\end{array}$ & $\begin{array}{l}\text { Não emite gases do efeito } \\
\text { estufa durante a operação. } \\
\text { Não ocupa áreas de } \\
\text { produção agrícola. }\end{array}$ & $\begin{array}{l}\text { Exige investimentos para } \\
\text { transmissão da energia } \\
\text { gerada. Pode ter impactos } \\
\text { na vida selvagem e } \\
\text { interfere em transmissões } \\
\text { de rádio e TV. }\end{array}$ \\
& $\begin{array}{l}\text { turbina que aciona } \\
\text { um gerador elétrico }\end{array}$ & & \\
\hline
\end{tabular}

QUADRO 05 - Gerador: Eólico

\footnotetext{
${ }^{7}$ Células a Combustível de variadas marcas e tipos

8 adaptado de Lorenzi (2009)

${ }^{9}$ Fehrenbacher in Bloom Energy - custo real sem subsídio.
} 
Um parque eólico é um grupo de turbinas eólicas, instaladas no mesmo local, utilizado para a produção de energia elétrica. Uma fazenda eólica de grande porte pode consistir de várias centenas de turbinas eólicas individuais, cobrindo uma grande área. Um parque eólico também pode ficar localizado no mar. Para que a energia eólica seja considerada tecnicamente aproveitável, é necessário que sua densidade seja maior ou igual a $500 \mathrm{~W} / \mathrm{m}^{2}$, a uma altura de 50 metros.

O potencial eólico brasileiro encontrado é estimado em modelos de previsão de tempo e estudos climáticos antigos. Além disto, estes modelos são validados para locais específicos das diferentes regiões do país. Por isto, o potencial eólico pode estar subestimado ou não representar a realidade de outro local, mesmo que próximo. No gráfico 06 mostra-se as isopletas da velocidade básica do vento em m/s, no Brasil, a uma altura de $50 \mathrm{~m}$ em relação ao solo.

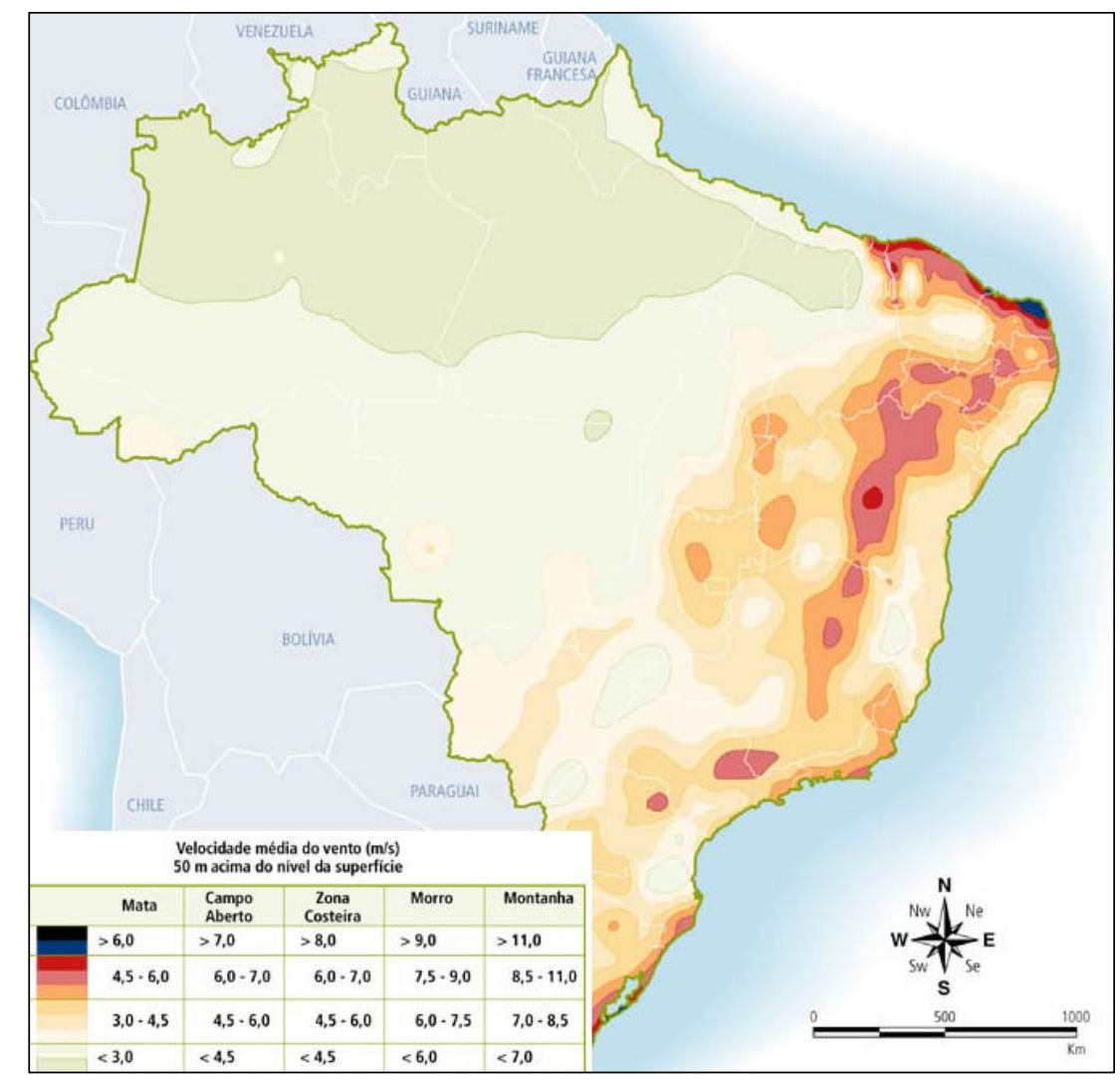

GRÁFICO 06 - Mapa das potencialidades eólicas do Brasil

ANEEL, 2011c 
Segundo Camargo (2005) apud ASME (1994) os geradores eólicos, podem ser classificados em relação a sua potência nominal instalada. O quadro 06 mostra esta divisão.

\begin{tabular}{|l|c|l|}
\hline \multicolumn{1}{|c|}{ Categoria } & Potência & \multicolumn{1}{c|}{ Utilização } \\
\hline $\begin{array}{l}\text { Pequeno } \\
\text { Médio } \\
\text { Grande }\end{array}$ & até $80 \mathrm{~kW}$ & Consumo local \\
\cline { 2 - 3 } & de $80 \mathrm{~kW}$ a $500 \mathrm{~kW}$ & Consumo local ou fornecimento para a rede \\
\hline
\end{tabular}

QUADRO 06 - Classificação por potência dos geradores eólicos Adaptado de Camargo (2005) apud ASME (1994) ${ }^{10}$

No quadro 07 apresentam-se algumas características dos Geradores Eólicos:

\begin{tabular}{ll}
\hline Disponível comercialmente & Sim \\
Faixa de capacidades & $1 \mathrm{~kW}$ a $200 \mathrm{MW}$ (uso modular) \\
Combustível & Deslocamento de ar \\
Eficiência & $25-35 \%^{11}$ \\
Emissões de Poluentes & Pequena \\
Emissões de $\mathrm{CO}_{2}\left(\mathrm{~g} / \mathrm{CO}_{2}\right)$ & 9,5 por kW ${ }^{12}$ \\
& Necessita de lugar específico para construção. Impactos \\
Outras características & visuais e possíveis impactos sonoros. \\
Custo do Investimento por kW & 1200 US $\$^{13}$ \\
Status comercial & Gerador disponível \\
\hline
\end{tabular}

QUADRO 07 - Visão Geral dos Geradores Eólicos

\footnotetext{
${ }^{10}$ American Society of Mechanical Engineers.

${ }^{11}$ Terciote (2002)

${ }^{12}$ Sovacool (2008)

${ }^{13}$ Tolmasquin (2007)
} 


\subsection{3 - Geração Hídrica}

A maior parte da produção de hidroeletricidade é realizada através de uma massa de água que está associada a uma barragem represada em certa altura de um rio. O potencial hidrelétrico brasileiro consiste em cerca de $260 \mathrm{GW}$. Contudo apenas 68\% desse potencial foi inventariado (ANEEL, 2011b). No quadro 08 sintetizam-se algumas características da fonte hídrica.

\begin{tabular}{|c|c|c|c|c|}
\hline Fonte & Obtenção & Usos & Vantagens & Desvantagens \\
\hline Hídrica & $\begin{array}{l}\text { A energia liberada } \\
\text { pela movimentação } \\
\text { de massas de água } \\
\text { move uma turbina } \\
\text { que aciona um } \\
\text { gerador elétrico }\end{array}$ & $\begin{array}{l}\text { Produção de energia elétrica. } \\
\text { Controle do nível de rios. }\end{array}$ & $\begin{array}{l}\text { Não emite poluentes } \\
\text { diretamente durante } \\
\text { operação. } \\
\text { A produção é controlada. }\end{array}$ & $\begin{array}{l}\text { Inundação de grandes } \\
\text { áreas, deslocamento de } \\
\text { populações. A construção } \\
\text { dessas usinas é cara e } \\
\text { demorada. }\end{array}$ \\
\hline
\end{tabular}

QUADRO 08 - Gerador: Hídrico

Pequena Central Hidrelétrica (PCH) teve sua primeira definição em 1982. Hoje sua definição é oficializada através das resoluções $n^{0}$ 394, de 1998 e a de $n^{0}$ 652, de 2003, da ANEEL e pode ser definida como toda usina hidrelétrica de pequeno porte, cuja capacidade instalada seja superior a 1 MW e inferior a 30 MW. Além disso, a área do reservatório deve ser inferior a 3 km² (ELETROBRAS, 1999; ANEEL, 1998a; ANEEL, 2003). A potência necessária para atender à demanda a ser estudada neste trabalho, estabelecida em $250 \mathrm{~kW}$, e portanto não se enquadra em uma $\mathrm{PCH}$ e sim em uma Mini Central Hidrelétrica $(\mathrm{MCH})$. O enquadramento está de acordo com a resolução da ANEEL 395 de 1998, no seu capítulo VI artigo 22º que trata dos aproveitamentos iguais ou inferiores a $1.000 \mathrm{~kW}(1 \mathrm{MW})$, que deverão ser comunicados em cumprimento ao artigo $8^{\circ}$ da lei $n^{\circ}$ 9.074, de 7 julho de 1995 (LUCCHESSI et al. 2002; ANEEL, 1998b). 
O quadro 09 sintetiza os valores de potência e os enquadramentos legais por queda d’água de acordo com a legislação brasileira.

\begin{tabular}{|l|r|r|}
\hline \multicolumn{1}{|c|}{ Categoria } & Potência & \multicolumn{1}{c|}{ Queda } \\
\hline Microcentral & Até $100 \mathrm{~kW}$ & Entre 15 e 50 metros \\
\cline { 2 - 3 } Minicentral & Entre $100 \mathrm{~kW}$ e $1 \mathrm{MW}$ & Entre 20 e 100 metros \\
\hline PCH & Entre $1 \mathrm{MW} \mathrm{e} 30 \mathrm{MW}$ & Entre 25 e 130 metros \\
\hline
\end{tabular}

QUADRO 09 - Classificação por potência e queda d'água para geradores hídricos segundo a legislação brasileira

A seleção do melhor local para a implantação deve ser feita considerando-se os Estudos de Inventário da bacia hidrográfica em foco. Esse estudo, de acordo com a orientação do Setor Elétrico, deve ser realizado, obrigatoriamente, antes de qualquer Estudo de Viabilidade/Projeto Básico, segundo a metodologia preconizada no Manual de Inventário da ANEEL/ELETROBRÁS. Os estudos de inventário muitas vezes não consideram locais com pequenos potenciais, deixando de levantar locais atraentes para centrais com baixa potência. Observam-se, no quadro 10, algumas características dos pequenos geradores hídricos:

\begin{tabular}{ll}
\hline Disponível comercialmente & Sim \\
Faixa de capacidades & $100 \mathrm{~kW}$ a $10 \mathrm{MW}$ ou menores \\
Combustível & Deslocamento de água \\
Eficiência & Até $95 \%$ \\
Emissões de Poluentes & Pequena \\
Emissão Total de $\mathrm{CO}_{2}\left(\mathrm{~g} / \mathrm{CO}_{2}\right)$ & 10 por $\mathrm{kW}^{14}$ \\
Outras características & Necessita de lugar específico para construção \\
Custo do Investimento por $\mathrm{kW}$ & 1100 US\$ ${ }^{15}$ \\
Status comercial & Gerador amplamente disponível \\
\hline
\end{tabular}

QUADRO 10 - Visão Geral dos Geradores Hídricos

\footnotetext{
${ }^{14}$ Sovacool (2008)

15 Tolmasquin (2007)
} 


\subsection{4 - Gerador Solar Fotovoltaico}

Células Fotovoltaicas convertem luz em eletricidade. A conversão direta da energia solar em corrente elétrica é realizada nas células solares através do efeito fotovoltaico, que consiste na geração de uma diferença de potencial elétrico através da radiação eletromagnética.

No quadro 11 sintetizam-se algumas características da fonte solar:

\begin{tabular}{|c|c|c|c|c|}
\hline Fonte & Obtenção & Usos & Vantagens & Desvantagens \\
\hline Solar & \begin{tabular}{|} 
Laminas ou painéis \\
recobertos com material \\
semicondutor capturam \\
luminosidade do Sol para \\
gerar corrente elétrica
\end{tabular} & Produção de energia elétrica. & $\begin{array}{c}\text { Não emite gases do efeito } \\
\text { estufa durante a operação. } \\
\text { Não precisa de turbinas ou } \\
\text { geradores para produção de } \\
\text { energia elétrica. }\end{array}$ & $\begin{array}{c}\text { Exige investimentos } \\
\text { iniciais de relativa monta } \\
\text { para seu aproveitamento. } \\
\text { Alto Custo. }\end{array}$ \\
\hline
\end{tabular}

QUADRO 11 - Gerador: Solar.

Durante a década de 1980 e início de 1990, a maioria dos módulos fotovoltaicos eram utilizados como fonte de alimentação para áreas remotas, mas em torno de 1995 os esforços da indústria concentraram-se cada vez mais no desenvolvimento de construção de células fotovoltaicas integradas e usinas de energia fotovoltaicas para aplicações conectadas à rede.

A energia solar é uma das fontes naturais de energia e de baixo impacto ambiental na produção de energia elétrica. A radiação solar pode ser aproveitada em diferentes intensidades. De acordo com a localização geográfica, quanto mais perto do equador, mais energia solar pode ser potencialmente captada. As áreas desérticas, ou áreas onde há poucas nuvens e baixa umidade são as mais favoráveis à captação de energia solar. No gráfico 07 mostra-se o gráfico da radiação $\left(\mathrm{Wh} / \mathrm{m}^{2} / \mathrm{d}\right)$ no Brasil. As áreas mais avermelhadas são as que possuem maior quantidade de radiação solar e por isto mais propícias a implantação desta tecnologia. Consta na literatura que áreas com menos de $4000 \mathrm{Wh} / \mathrm{m}^{2} / \mathrm{d}$ não são recomendadas para implantação de unidades geradoras maiores. O gráfico da radiação solar brasileira não mostra estes valores: 


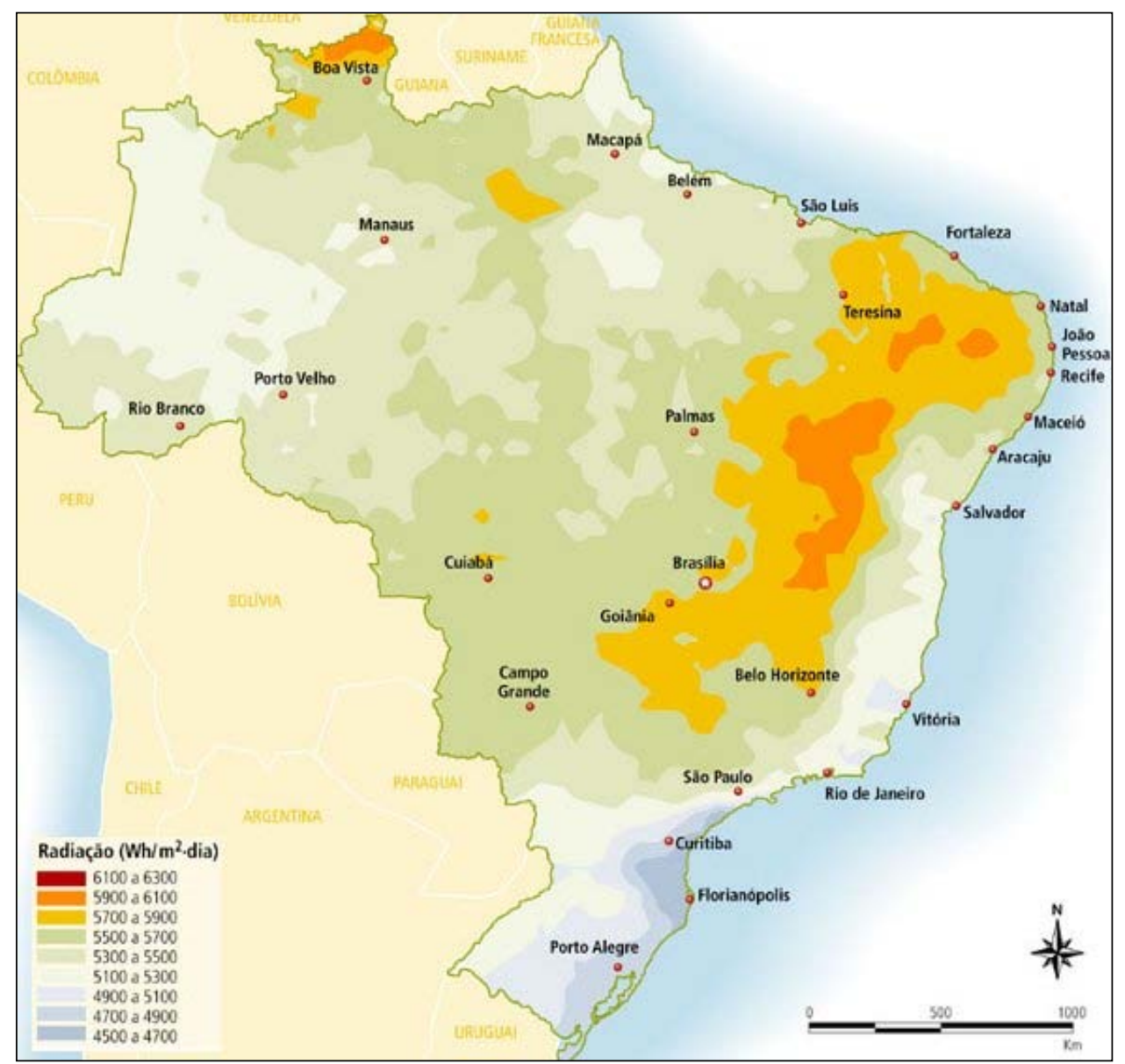

GRÁFICO 07 - Mapa Radiação solar global diária - média anual típica (Wh/m²/d)

ANEEL, 2011d

Observam-se no quadro 12 algumas características dos geradores solares fotovoltaicos:

\begin{tabular}{ll}
\hline Disponível comercialmente & Sim \\
Faixa de capacidades & $1 \mathrm{~kW}$ a $2 \mathrm{MW}$ \\
Combustível & Radiações Solares \\
Eficiência & $11-13,5 \%{ }^{16}$ \\
Emissões de Poluentes & Pequena \\
Emissão Total de $\mathrm{CO}_{2}\left(\mathrm{~g} / \mathrm{CO}_{2}\right)$ & 32 por kW ${ }^{17}$ \\
& Necessidade de grandes áreas para capacidades \\
Outras características & maiores, nuvens reduzem a eficiência. \\
Custo do Investimento por kW & 7000 US ${ }^{18}$ \\
Status comercial & Unidade Geradora Disponível \\
\hline
\end{tabular}

QUADRO 12 - Visão Geral dos Geradores Solares Fotovoltaicos

\footnotetext{
${ }^{16}$ INMETRO - Tabelas de Consumo / Eficiência Energética - Componentes Fotovoltaicos . Edição 04/11.

${ }^{17}$ Sovacool (2008)

${ }^{18}$ Tomalsquin (2002)
} 


\subsection{5 - Grupo Moto Gerador (GMG)}

O Grupo Moto Gerador (GMG) quando empregados em sistemas estacionários, geralmente utilizam como combustível o gás natural, o gás liquefeito de petróleo (GLP), o óleo Diesel ou óleos pesados residuais (LORA et al. 2006).

O Grupo Moto Gerador a diesel é considerado um dos dispositivos de menor custo para a geração de energia elétrica. O diesel é um hidrocarboneto econômico, quando utilizado para produção de energia elétrica pode poupar cerca 30\% do seu custo total se comparado a outras tecnologias de geradores a motor, segundo alguns estudos. O Quadro 13 sintetiza algumas características deste gerador:

\begin{tabular}{|l|c|c|c|c|}
\hline Fonte & Obtenção & Usos & Vantagens & Desvantagens \\
\hline GMG a Diesel & $\begin{array}{c}\text { Aquisição no } \\
\text { mercado }\end{array}$ & Produção de energia elétrica. & $\begin{array}{c}\text { Tecnologia amadurecida. } \\
\text { Não depende de fonte } \\
\text { insconstante. }\end{array}$ & $\begin{array}{c}\text { Poluente. } \\
\text { Lecessita de controle do } \\
\text { nível de ruído. }\end{array}$ \\
\hline
\end{tabular}

QUADRO 13 - Gerador: Diesel

São largamente utilizados e os mais desenvolvidos tecnicamente dentro do contexto tecnológico de geração de energia distribuída. Estão disponíveis desde pequenas capacidades, como de $5 \mathrm{~kW}$ para geração de energia de back-up residencial até motores de grande porte de potência de 30MW ou maior (LORA et al. 2006). O quadro 14 apresenta uma visão geral das características deste tipo de gerador:

\begin{tabular}{ll}
\hline Disponível comercialmente & Sim \\
Faixa de capacidades & $5 \mathrm{~kW}$ a $30 \mathrm{MW}$ ou maiores \\
Combustível & Gás natural, óleo diesel, gás de aterro sanitário, etc. \\
Eficiência & 25 a $45 \%$ \\
Emissões de Poluentes & Pode necessitar de controle das emissões para $\mathrm{NO}_{x}$ e CO \\
Emissão total de $\mathrm{CO}_{2}\left(\mathrm{~g} / \mathrm{CO}_{2}\right)$ & $443-1005$ por kW (dependendo da fonte) \\
& Adequação aos sistemas de cogeração (a eficiência pode \\
Outras características & ultrapassar $80 \%)$ \\
Custo do Investimento por kW & 500 US\$ \\
Status comercial & Gerador amplamente disponível \\
\hline
\end{tabular}

QUADRO 14 - Visão Geral do Grupo Moto Gerador 
Esta tecnologia tem o seu interesse devido à sua elevada eficiência, ao baixo custo inicial e à facilidade de manutenção, resultado de uma infraestrutura de serviços bem estabelecida. Relata-se ainda que o desenvolvimento de motores menores que 250 kW tem sido alvo de melhorias em termos de eficiência, potência específica e nível de emissão de poluentes. Novos materiais possibilitam a redução de peso, custo e perdas de calor (LORA et al. 2006).

\section{3 - Geração Distribuída}

Tanto para Ackermann et al. (2001) quanto para Moreira et al. (2004) a definição de geração distribuída (GD) se altera entre os países, motivada pelas diferentes regulamentações governamentais. Algumas nações usam a definição baseada no nível de tensão, na origem da energia, no local de consumo ou no valor máximo de potência.

No Brasil, a operação dos sistemas de geração distribuída teve início na década de 90 com a reforma do setor elétrico e ganhou definição oficial através do Decreto $\mathrm{n}^{\circ}$ 5.163, Art. 14, de 30 de Julho de 2004 (LEME, 2009; DIAS et al. 2005).

Pela lei, considera-se geração distribuída a produção de energia elétrica proveniente de empreendimentos de agentes concessionários, permissionários ou autorizados conectados diretamente no sistema elétrico de distribuição do comprador (BRASIL, 2004).

Entre as exceções da lei brasileira estão aquelas proveniente de empreendimento hidrelétrico com capacidade instalada superior a $30 \mathrm{MW}$ e termelétrico, inclusive de cogeração, com eficiência energética inferior a 75\%, sendo que os empreendimentos termelétricos que utilizem biomassa ou resíduos de processo como combustível não estarão limitados a este percentual de eficiência energética (BRASIL, 2004).

Frente a uma gama variada de conceitos foi necessário adotar-se uma definição que seja a referência para as análises e considerações deste trabalho. A geração 
distribuída pode ser definida como aquela onde a produção de energia visa atender a cargas próximas conectadas diretamente ao consumidor, sem a necessidade de transporte de energia através da rede de transmissão (DIAS et al. 2005).

Seu papel neste estudo é delinear o campo de atuação do modelo projetado. As unidades geradoras simuladas devem atender diretamente a carga demandada, sem a necessidade ser suplementada pela energia oferecida pela rede.

Entre os tipos de geradores mais utilizados na GD estão as células a combustível, as microturbinas a gás, os motores de combustão interna, os painéis fotovoltaicos, as pequenas centrais hidrelétricas (PCH’s), as usinas eólicas e a cogeração tendo por fonte resíduos (LORA et al. Cap. 2 e 3, 2006).

\subsection{1 - Características da geração distribuída}

Pode-se trabalhar com a geração distribuída tanto fazendo uso de sua capacidade como Fonte de Energia ou como Reserva Descentralizada. Possui a função de atender à demanda de cargas próximas ao seu local de distribuição, suprir excesso de demanda (demanda de ponta), auxiliar como sistema secundário de suprimento, melhorar qualitativamente as condições do fornecimento de energia, reduzir os riscos de instabilidade e aumentar a confiabilidade no suprimento de energia (COGEN, 2009).

A sua adoção possibilita a diminuição dos investimentos e a redução dos custos globais de produção e transporte de eletricidade, de construção de subestações, de grandes usinas geradoras e na instalação de longas linhas de transmissão.

A importância deste modo de geração vem aumentando nos últimos anos devido à busca por tecnologias que resultem em maior eficiência, confiabilidade e menor custo, mesmo quando trabalhando em baixas potências. 
Moreira et al. (2004) através de bibliografias como INEE (2001) ${ }^{19}$ e Hollanda (2004) ${ }^{20}$ copilou uma série de características da GD na tentativa de produzir uma lista de vantagens e desvantagens. No quadro 15 apresenta-se, de forma sintética, uma adaptação da lista de vantagens.

\section{Vantagens da Geração Distribuída}

Atendimento mais rápido ao crescimento da demanda, ou à demanda reprimida, por ter um tempo de implantação inferior ao de acréscimos à geração centralizada e reforços das respectivas redes de transmissão e distribuição

Aumento da confiabilidade do suprimento, por adicionar fonte não sujeita a falhas na transmissão e distribuição e por constituir uma geração mais próxima às solicitações do mercado

Aumento da estabilidade do sistema elétrico, pela existência de reservas de geração distribuídas, consequentemente, exigindo menores reservas centrais

Redução das perdas na transmissão e dos respectivos custos e adiamento no investimento para reforçar o sistema de transmissão

Redução dos riscos de planejamento, pois normalmente representam projetos menores

Aumento da eficiência energética, redução simultânea dos custos das energias elétrica e térmica, colocação dos excedentes da primeira no mercado a preço competitivo

Redução de impactos ambientais da geração, pela melhor utilização dos combustíveis tradicionais e, em certos tipos de cogeração, com a eliminação de resíduos industriais poluidores;

Benefícios gerais decorrentes da maior eficiência energética obtida pela conjugação da geração distribuída com a geração centralizada e das economias resultantes

Maiores oportunidades de comercialização e de ação da concorrência no mercado de energia elétrica, na diretriz das Leis que reestruturaram o setor elétrico

Equacionamento do 'Power Purchase Agreement' (PPA) ${ }^{21}$

Maior prestação de serviços ancilares ${ }^{22}$

Baixa exposição cambial

Menores reservas centrais

Uso intensivo de mão de obra

Custos marginais decrescentes

Possível uso de Créditos de carbono

O período de construção é, em geral, bastante reduzido em relação às alternativas convencionais

Possibilidade de utilização de insumos energéticos de menor valor comercial, permitindo a minimização

dos custos operacionais de um projeto

Minimização dos impactos ambientais redundantes do porte das instalações e maior dispersão espacial

No caso da cogeração, pode ser atribuída a vantagem de uma maior eficiência energética no uso da

energia com reflexos no ponto de vista ambiental, frente à produção exclusiva de calor e potência.

QUADRO 15 - Lista de Vantagens da Geração Distribuída

\footnotetext{
${ }^{19}$ Instituto Nacional de Eficiência Energética. Notas sobre Geração Distribuída - Introdução. Disponível em <http://www.inee.org.br/forum_downloads.asp?Cat=forum> Julho, 2001.

${ }^{20}$ HOLLANDA, J. B. de. Mitigando Incertezas de Planejamento com a GD: Estudo demonstra que a GD reduz custo da energia elétrica a longo prazo. 2004.

${ }^{21}$ Contratos de suprimento de energia celebrados entre empresas Geradoras e concessionárias Distribuidoras supridas.

${ }^{22}$ Serviços agregados de forma indireta à venda de energia.
} 
As desvantagens da geração distribuída são poucas, mas pode-se destacar que a complexidade da operação tende a se tornar maior, dado ao maior planejamento, controle, manutenção, medidas de segurança, e a avaliação por parte do produtor se a diminuição da demanda pela distribuidora não afetará os preços correntes anteriormente praticados.

Uma maior inserção de sistemas de geração distribuída junto as redes de distribuição poderia proporcionar uma opção a um sistema de rede muito regulamentada e conseqüentemente taxada por suas controladoras. Este contexto permite um excedente financeiro ao produtor elétrico local, através da venda de excedentes da geração favorecendo a promoção do desenvolvimento regional, com vantagens sob o enfoque econômico e social.

Em países com uma grande extensão territorial como o Brasil, onde muitas regiões isoladas sofrem pela carência de energia elétrica, deve-se viabilizar o financiamento de projetos que levem em conta a geração distribuída. As populações mais necessitadas teriam uma série de benefícios associados ao acesso à energia elétrica e o consequente avanço social proporcionado pela mesma. Com a melhoria de vida destes lugares ermos poderia haver a redução da imigração destas populações necessitadas por qualidade de vida, evitando imigrações para centros urbanos já exauridos em vários setores.

\section{4 - Simulação}

A simulação permite emular o funcionamento dos geradores e equipamentos e assim avaliar os impactos associados as mudanças estruturais em um modelo. $\mathrm{O}$ objetivo é minimizar ou maximizar algumas medidas de desempenho do sistema. Os impactos são determinados por meio da análise das variáveis de saída.

A otimização pode ser definida como um processo que combina diferentes variáveis controladas, com a finalidade de encontrar um ou mais resultados que atendam uma saída desejável do modelo de simulação. O desenvolvimento de técnicas de otimização permite a melhoria da coordenação e do controle das atividades administrativas, inclusive na alocação de recursos para estas atividades. Estes dois 
processos, simulação e otimização, vêm se integrando após estarem separados até os anos 2000 (ALMEIDA FILHO, 2006).

Defini-se análise de sensibilidade como a técnica que permite, de forma controlada, perceber o comportamento das variações de parâmetros, ou os recursos disponíveis nas simulações já otimizadas.

Considera-se que as variáveis não são igualmente importantes ao seu efeito sobre a resposta do modelo. Por isto, deve-se selecionar as variáveis que irão compor o espaço de busca da otimização, uma vez que quanto menos variáveis houver, mais rápida torna-se a otimização (ALMEIDA FILHO, 2006).

\subsection{1 - $\underline{\text { Software HOMER }}$}

Utilizou-se do software Hybrid Optimization Model for Electric Renewables, Modelo Híbrido de Otimização para Geradores Elétricos Sustentáveis, em tradução livre, que forma o acróstico HOMER, com as palavras originais em inglês. O programa HOMER, empregado neste trabalho, é utilizado na modelagem com a finalidade de simular os sistemas híbridos de microgeração de energia.

Desenvolvido pelo National Renewable Energy Laboratory (NREL), órgão ligado ao U.S. Departament of Energy (DOE), seu objetivo é prever o desenho de sistemas descentralizados, realizando a avaliação de um grande número de configurações. A ideia é identificar o sistema de menor custo capaz de suprir à demanda de energia elétrica de um determinado consumidor.

O programa permite a comparação de diversas alternativas, possibilitando análises de sensibilidade que avaliam o impacto da variação dos parâmetros de carga sobre o sistema. É, ainda, utilizado para simplificar a tarefa de avaliar os projetos de redes, conectadas ou não.

Além disto, o software permite a análise de sensibilidade e comparação entre os diversos tipos de fontes de energias sustentáveis, obtendo resultados numéricos e gráficos de cenários do caso estudado em seus aspectos econômicos e técnicos (NREL, 2010). 
Esta ferramenta computacional já foi extensivamente testada e aplicada em apoio à decisão de projetos de energia distribuída e emissões de GEE em todo mundo, inclusive com células a combustível (BECCALI et al. 2008; KHAN \& IQBAL, 2005).

A característica-chave do programa é a de simular os principais tipos de energias sustentáveis disponíveis comercialmente no mundo. A simulação permite a comparação entre eles, já que fornece uma lista dos processos classificados de acordo com o Custo da Energia (COE) e o valor presente líquido de cada sistema.

O RETScreen Clean Energy Project Analysis Software foi utilizado como uma ferramenta complementar de apoio. O software, fornecido sem custos, pode ser usado para avaliar a produção energética, os custos, reduções de emissões, a viabilidade financeira e de risco para vários tipos de Energias renováveis e tecnologias energeticamente eficientes (RETs). Possui um banco de dados de fontes renováveis muito extenso. Foi utilizado de forma suplementar.

\section{5 - Análise Financeira}

\subsection{1 - Valor Presente Líquido (VPL), Taxa Interna de Retorno (TIR) e Payback}

Deve-se, em um estudo sobre análise técnica e econômica de unidades geradoras de energia, levar em consideração o cálculo do Valor Presente Líquido (VPL). Segundo Marchetti (1995), o VPL revela uma expectativa de ganho de capital acima (se possuir um valor positivo) e abaixo (se negativo) do retorno mínimo esperado, considerado na taxa de desconto do fluxo de caixa. Isto significa que o Valor Presente das Entradas de Caixa é, no mínimo, igual ao Valor Presente das Saídas de Caixa, então o investimento é viável. Nos casos em que o VPL for negativo, por não satisfazer as expectativas de retorno, rejeita-se a viabilidade do projeto.

Tratando-se o VPL de uma medida de valor que requer a definição de uma taxa de desconto, não há um único valor presente líquido, mas inúmeros, um para cada taxa de desconto considerada. Entretanto, a uma taxa de desconto apropriada, o VPL é a medida do mérito que oferece maior segurança na decisão, porque supõe que os fluxos 
gerados possam ser reinvestidos à taxa de desconto considerada, além de em conta o investimento inicial e seu custo de oportunidade.

Em termos práticos, para estes estudos, deve-se encontrar de forma complementar a Taxa Interna de Retorno (TIR), que é uma taxa única de juros que resume os resultados de um projeto. A TIR sobre um investimento é o retorno necessário que resulta em um VPL zero quando ela é usada como a taxa de desconto (ROSS et al., 2008; PILÃO \& HUMMEL, 2003). Seu cálculo não exige o emprego de uma taxa mínima de desconto. A TIR é suficiente para decidir a aceitação ou rejeição de um empreendimento isolado, mas não é suficiente quando se trata da escolha entre várias alternativas. Neste último caso, deixa de ser medida satisfatória. A TIR mais elevada não mostra sempre a melhor escolha, pois a maior taxa nem sempre significa o maior retorno financeiro, sem considerar o VPL. Isto porque ao se comparar o fluxo de caixa total, o fluxo da alternativa de taxa de desconto mais baixa pode ter um retorno mais lento, no entanto pode possuir um VPL mais alto (ROSS et al. 2008; MARCHETTI, 1995).

Deve-se levar em conta também o payback period, conhecido apenas como payback, prazo de recuperação do capital ou período de retorno. É o período de tempo que um projeto leva para recuperar o capital inicialmente investido. É usualmente utilizado na avaliação de projetos mutuamente exclusivos. Na prática, como ocorre fluxo de caixa de valor variável ao longo do tempo, é necessário recorrer a outras expressões. Com base na regra do período de retorno, um investimento é aceitável se o seu período de retorno calculado for menor do que o número pré-estabelecido de anos. Esta é uma ferramenta útil que permite a apreciação da rentabilidade de um investimento ao longo do tempo. Em geral, quanto menor o payback melhor o investimento. É prática corrente na análise de investimentos fixar-se um período de recuperação máximo aceitável. Este período é estabelecido pelo investidor. Apesar da sua popularidade, o payback tem como desvantagem não levar em conta o valor do dinheiro no tempo, por isto adota-se uma variação no período de retorno, o período de retorno descontado, que corrige esse problema em particular. 


\section{METODOLOGIA}

Neste capítulo é efetuada uma descrição de todos os métodos utilizados no trabalho. O programa de computação e outros métodos empregados procuraram ser descritos com clareza, de tal forma que se possa reproduzir o mesmo estudo e obter os mesmos resultados.

As equações presentes dos itens 4.1.3 ao 4.1.5 têm, como fonte, técnicas de administração financeira descritas em Ross et al. (2008) e foram ajustadas ao estudo em questão. Os itens 4.1.6 e 4.1.7 foram adaptados pelo autor a partir do software HOMER.

\subsection{Modelagem}

\subsection{1 - Utilização do software HOMER}

Utilizou-se, fundamentalmente, o software HOMER para efetuar a modelagem. Ao projetar o sistema elétrico tomaram-se decisões, sobre a configuração do sistema, que se referem ao tipo, quantidade e dimensão dos componentes que devem ser utilizados. Assim foi possível comparar o funcionamento de cada equipamento utilizado no projeto, respeitando-se as características técnicas e padrões de funcionamento característicos.

Os dados de input ao software serviram para que o programa fizesse os cálculos do balanço energético para cada uma das 8760 horas do ano. Para cada hora comparouse, pelo software, a demanda de energia com a capacidade do sistema, indicando em cada ciclo como devem ser operados os geradores e as cargas das baterias sujeitas ao descarregamento até o período de 20 anos. 


\subsection{2 - Otimização e Análise de sensibilidade}

Com a otimização determinou-se a mistura dos componentes que compõem o sistema, o tamanho ou a quantidade de cada um. No processo de análise de sensibilidade executaram-se múltiplas otimizações, sob um conjunto de hipóteses de entrada, para avaliar os efeitos das incertezas ou alterações nas entradas do modelo, como nas variáveis sobre as quais o projetista do sistema não tem nenhum controle, tais como a velocidade do vento ou o preço do combustível no futuro. Nesta análise, ainda procederam-se a várias interações para avaliar os diferentes cenários gerados, podendose constatar certas tendências do sistema.

Por meio deste software também foram realizadas as análises de sensibilidade e a comparação entre os diversos tipos de fontes de energias sustentáveis, obtendo-se resultados numéricos e gráficos de cenários otimizados do caso estudado em seus aspectos econômicos e técnicos.

\subsection{3 - Cálculo do Valor Presente Líquido (VPL)}

Calculou-se o VPL pela equação:

$$
V P L=\sum_{t=1}^{n} \frac{\mathrm{FC}_{\mathrm{t}}}{(1+i)^{t}}-I_{0}
$$

Onde:

$V P L=$ Valor Presente Líquido

$\mathrm{FC}_{\mathrm{t}}=$ Fluxo de Caixa do período $t$ (Receitas - Despesas)

$I_{0}=$ Investimento inicial do projeto

$i$ = taxa de desconto (Taxa Mínima de Atratividade - TMA)

$t(1 ; n)=$ período abrangido pelo projeto 
O cálculo do VPL considerou o valor do investimento inicial e seu custo alternativo. Em conseqüência, permitiu comparar alternativas de investimentos e estabelecer uma ordem de preferência e uma ordem métrica, para indicar quanto uma alternativa é mais atrativa que outra.

\subsection{4 - Cálculo da Taxa Interna de Retorno (TIR)}

Para o cálculo da TIR levou-se em conta que a aceitação do investimento se deu quando a taxa interna de retorno esperada foi igual ou maior do que a taxa de aceitação definida. A TIR é o método que nos permitiu encontrar a remuneração do investimento em termos percentuais.

Calculou-se a TIR pela equação:

$$
\sum_{t=1}^{n} \frac{\mathrm{FC}_{\mathrm{t}}}{(1+i)^{t}}-I_{0}=0
$$

Onde:

$\mathrm{FC}_{\mathrm{t}}=$ Fluxo de Caixa do período $t$ (Receitas - Despesas)

$I_{0}=$ Investimento inicial do projeto

$i=$ Taxa Interna de Retorno (TIR)

$t(1 ; n)=$ período abrangido pelo projeto

\subsection{5 - Cálculo do payback descontado}

Para que se aproximasse mais da realidade, adaptou-se o payback com uma taxa de atualização positiva, considerando desta forma o valor do dinheiro ao longo do 
tempo. Isto é denominado payback descontado e os cálculos foram realizados conforme a equação (3).

$$
\sum_{t=1}^{n}\left[\frac{B_{t}-C_{t}}{(1+i)^{t}}\right] \leq I_{0}
$$

Onde:

$n$ = é a variável tempo, que indica o número de períodos

$t(1 ; n)=$ período abrangido pelo projeto

$B$ = benefícios

$C=$ custos relevantes, excluindo os custos inicias

$i=$ taxa de desconto (Taxa Mínima de Atratividade)

$I_{0}=$ Investimento inicial do projeto

\subsection{6 - Cálculo do Custo de Energia (COE)}

Define-se o Custo de Energia - Cost of Energy (COE) como o custo médio / kWh de energia elétrica útil produzida pelo sistema. Para se calcular o COE, dividiu-se o custo anual de produção de eletricidade pela produção total de energia elétrica útil. A equação (4) foi utilizada para a definição deste custo.

$$
\operatorname{COE}=\frac{C_{m}}{E_{u}}
$$

Onde:

$C_{m}=$ é o custo médio em $\mathrm{kWh}$

$E_{u}=$ é a energia média útil produzida pelo sistema 


\subsection{7 - Cálculo do ponto de equilíbrio da rede}

Foi possível calcular a distância no qual o valor presente líquido da ampliação da rede é igual ao valor presente líquido do sistema distribuído, comparando-se o custo da carga fornecida pelo sistema distribuído com o custo da carga fornecida pela rede de distribuição, mais seu custo de ampliação até o centro de consumo. O custo do sistema autônomo é independente da distância da ampliação da rede, enquanto o custo da ampliação da rede depende da distância a ser construída. À distância em que os custos se igualam chama-se Ponto de Equilíbrio da Rede (PER) e é expresso pela fórmula:

$$
P E R=\frac{V P L \cdot F R C(i, R)-C_{r} \cdot E_{d}}{C_{c} \cdot F R C(i, R)+C_{o m}}
$$

Onde:

$V P L=$ Valor presente líquido total do sistema distribuído

$F R C=$ Fator de Recuperação do Capital

$i=$ Taxa de investimento

$R=$ Tempo de vida do projeto

$C_{r}=$ Custo da energia da rede de distribuição

$E_{d}=$ Demanda anual elétrica total em $\mathrm{kWh}$

$C_{c}=$ Custo de Capital da ampliação da rede de distribuição

$C_{o m}=$ Custo de operação e manutenção da rede de distribuição 


\subsection{8 - Orçamento}

Através de cotações de mercado obtiveram-se os valores dos componentes, o que subsidiou a formulação das curvas de custos. Além dos equipamentos, levaram-se em conta para a composição de custos os valores das instalações, das manutenções, da mão de obra, de estocagem de energia, da ampliação da rede e a taxa líquida de juros anual. O sistema de cálculo dos custos englobou os valores de investimento, de reposição dos equipamentos, de combustível, de operação e de manutenção.

\subsection{9 - Viabilidade técnica e econômica}

Para a realização da viabilidade técnica e econômica foram utilizadas as equações apresentadas acima, além de se utilizar conhecimentos de análise de custos em projetos de investimento. Ela foi feita através da comparação dos custos das unidades geradoras estudadas, com as restrições descritas por Florio et al. (2003) que afirma que, no caso dos investimentos produtivos tais como as instalações industriais, as taxas de rentabilidade financeira são geralmente muito superiores a $10 \%$ reais ${ }^{23}$. No caso de infraestruturas, com concessão de subvenção ${ }^{24}$, as taxas de rentabilidade financeira são geralmente inferiores, ou mesmo negativas, em parte devido à estrutura de preços destes setores.

Por isto a Taxa Mínima de Atratividade (TMA) adotada neste estudo foi de 14\% ao ano, valor utilizado pela CEMIG no projeto 'Morro do Camelinho', descrito operacionalmente em Camargo (2005) e financeiramente em Lisboa (2010), cujo valor atual é ligeiramente superior ao utilizado em alguns fundos de investimento. Considerou-se, como vida útil do sistema, um período de 20 anos.

\footnotetext{
${ }^{23}$ Taxa deflacionada para excluir as alterações do nível geral de preços (por exemplo, as taxas de juro reais são as taxas de juro nominais menos a taxa de inflação).

${ }^{24}$ Ajuda financeira paga pelo governo.
} 


\subsubsection{0 - Comparação entre alternativas de investimento}

Utilizou-se um conjunto de técnicas para permitir a comparação entre as alternativas de investimento de forma científica. As diferenças que marcam as alternativas foram expressas em termos quantitativos. Para isso, fez-se uso, basicamente, de cálculos matemáticos de engenharia financeira. Após a verificação de que todas as variáveis que influem significativamente no sistema foram convenientemente estudadas escolheu-se como melhor alternativa, sob a ótica econômica, aquela que, no prazo estipulado, propiciou a maior rentabilidade ou menor custo.

\subsubsection{1 - $\underline{\text { Fluxo de Caixa }}$}

Fluxo de Caixa não apresenta definição diferente das amplamente exemplificadas na área contábil/financeira. São as contribuições monetárias (entradas e saídas) ao longo do tempo.

\subsubsection{2 - $\underline{\text { Risco e Incerteza }}$}

Devido à incapacidade de se recolherem todas as informações relacionadas à execução de um investimento, o risco integrou o método de realização desta análise. Assim, foram tomadas decisões sob importante grau de incerteza, sendo impraticável eliminá-lo totalmente. O risco em uma atividade ocorre quando surgem alterações nas condições futuras de variáveis relevantes como o preço, quantidade, disponibilidade de matéria prima, que comprometem o retorno esperado do investimento.

Quando as probabilidades de ocorrência e/ou, estados futuros da variável não são conhecidos, diz-se que há incerteza. Uma vez harmonizadas e identificadas as distribuições das variáveis importantes do projeto, comumente identificadas pela análise 
de sensibilidade, simulam-se valores dessas variáveis e verificaram-se seus impactos nos indicadores escolhidos (como o VPL, a TIR e o Payback). Estes resultados são significantes para a tomada de decisão.

\subsubsection{3 - Uso do Grupo Moto Gerador (GMG)}

Neste trabalho se considerou o GMG - Diesel como um gerador de energia como um padrão de referência.

\subsection{Parâmetros de Entrada}

Destaca-se que para se encontrar os valores enviados ao software HOMER que seriam processados, ou seja, os parâmetros de entrada, foi necessário encontrar dados existentes confiáveis, analisá-los e em alguns casos adaptá-los para, só então, poder aplicá-los como input do software. Neste tópico são descritos e discutidos os principais parâmetros de entrada no HOMER utilizados para ajustar as diversas configurações possíveis.

\subsection{1 - Demanda energética em kW do local escolhido}

Sistemas isolados de suprimento de energia atendendo ao consumidor, ou a um grupo com a mesma subestação, requerem uma distribuição da carga considerando a restrição de horário para determinadas utilizações, minimizando picos de demanda e, conseqüentemente, diminuindo o valor do investimento e do kWh. 
A demanda estudada foi definida com base em dois componentes: demanda de potência e consumo de energia. A demanda de potência foi definida em quilowatt e corresponde ao máximo da potência elétrica solicitada pelo consumidor. O consumo de energia foi definido em quilowatt-hora e correspondeu ao valor acumulado da potência elétrica consumida por um período de utilização de 365 dias.

Para a criação da curva de demanda deste trabalho necessitou-se de duas etapas. A primeira etapa teve como base teórica o artigo de Hermsdorff et al. (2003) e a resolução 456 da ANEEL (2000). Para simplificar a estimativa da demanda durante os 20 anos da operação do sistema, neste momento a curva foi considerada invariável de mês para mês e ano para ano. Ela leva em consideração que a demanda elétrica tem por base o consumo elétrico brasileiro, respeitando os horários de pico. Observa-se o gráfico 08:

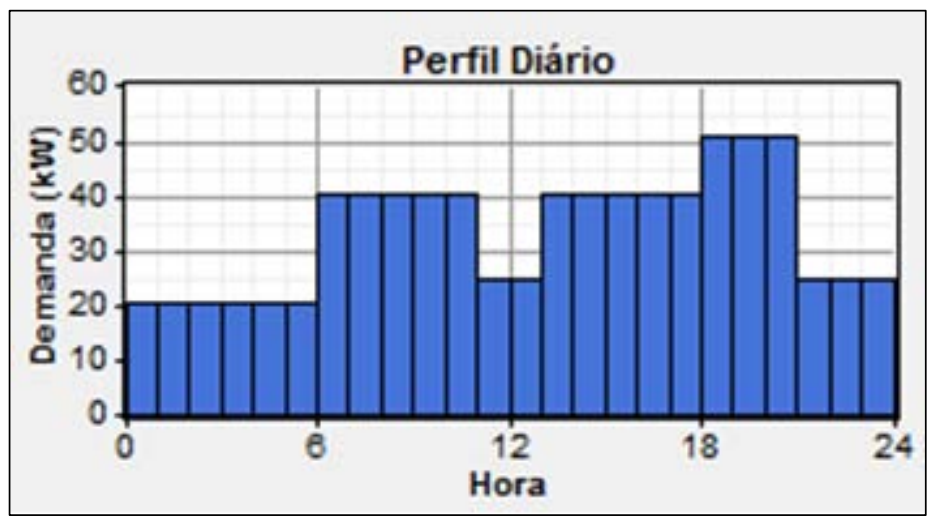

GRÁFICO 08 - Perfil Diário do Consumo

Pode se observar por meio da figura que a demanda de carga é a mais baixa nos horários entre 0 e 6 da manhã; das 6 até as 18:00 horas a demanda é maior, excetuandose um período de 2 horas entre 11 e 13:00, que corresponde ao horário de almoço. Das 18 até 21:00 horas acontece o horário de pico. A partir deste horário a carga volta a diminuir obtendo um padrão um pouco inferior ao encontrado na maior parte do horário comercial. Após as 24 horas o ciclo recomeça.

A configuração para este perfil diário tem um fator de carga de 0,606. O fator de carga é a relação entre a demanda média do sistema e a demanda máxima observada no mesmo intervalo. Fatores de carga altos significam uma qualidade alta no uso da energia do sistema. O fator de carga depende estritamente do tipo de projeto que se pretende 
atender. Em projetos com baixo fator de carga é necessário um estudo específico para atendê-lo. Quando a demanda apresenta um fator de carga muito baixo, o custo de energia se eleva muito.

A segunda etapa foi feita a partir dos dados do Perfil Diário de Carga e com ele foi construído o gráfico 09, apresentado como Mapa de Distribuição. Este gráfico é a mais fiel ilustração do comportamento do consumidor e, portanto, o efetivamente utilizado na simulação. Para sua formulação foi utilizada a potência média da hora de consumo. A esta média adicionou-se uma interferência aleatória de 1,7\% de hora em hora e outra interferência de $2 \%$ de um dia para o outro. A interferência aleatória permite que os dados de carga se tornem mais realista. Esta interferência, também chamada de ruído, afeta a carga máxima (ou de pico) sem alterar a média. O consumo mensal médio está em 24.000 kWh. No gráfico 08 pode-se observar um valor de pico de $56 \mathrm{~kW}$.

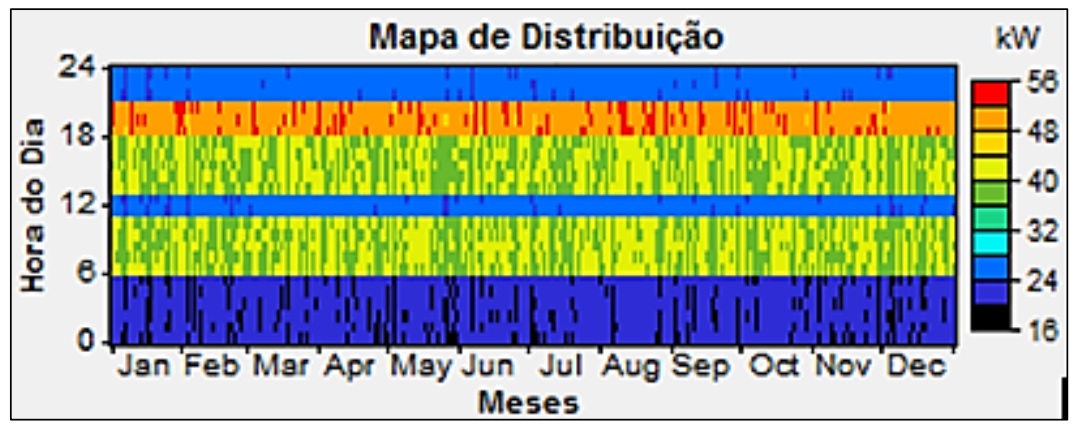

GRÁFICO 09 - Mapa de distribuição de carga ao longo do ano

\subsection{2 - Potências das Unidades Geradoras}

A escolha para o valor de potência teve por base dois fatores: primeiro, a escolha de uma potência que conseguisse atender à dimensão das instalações propostas. Por exemplo, a demanda energética de um conjunto de salas, de um laboratório, de um pequeno hospital, de pequenas indústrias, ou uma linha de produção de um setor fabril. O segundo fator foi uma configuração tradicional no mercado em que são disponibilizados geradores da ordem de $250 \mathrm{~kW} / 313 \mathrm{kVA}$ de potência. 


\subsection{3 - Tarifas de energia da rede}

As tarifas de energia elétrica não têm um mesmo valor para todos os consumidores. Para se definir o preço kWh deve-se levar em conta que elas se diferenciam entre grupos tarifários, de acordo com a tensão de fornecimento, o instante de consumo, o tipo de tarifa e a classe do consumidor.

As tarifas de demanda de potência são fixadas em reais por quilowatt e as tarifas de consumo de energia elétrica nas concessionárias de energia em reais são definidas em megawatt-hora (R/MWh) e especificadas nas contas mensais do consumidor em reais por quilowatt-hora.

A primeira distinção ocorre no fornecimento de energia para sistemas de alta tensão ou para sistemas de baixa tensão, inferiores a 2,3 quilovolts $(\mathrm{kV})$. Os consumidores alocados nos grupos de alta tensão em geral pagam uma tarifa mais barata, pois o custo relativo desse atendimento é menor, devido às correntes mais baixas. Esses consumidores estão sujeitos a uma tarifação do tipo binomial, pagando pela potência demandada em quilowatts $(\mathrm{kW})$ e pelo consumo em quilowatts/hora (kWh).

Além do nível de tensão, os valores das tarifas podem ser diferenciados dependendo do horário e época do ano em que ocorre o consumo. Por exemplo, nos horários chamados de pico de consumo (alto consumo) e épocas propícias à geração hídrica ou não, que são chamados de Ponta Úmida e Ponta Seca. Havendo disponibilidade de energia no sistema, podem existir tarifas especiais mais baratas (ANEEL, 2005).

Segundo DIEESE (2010) a grande maioria dos consumidores de alta tensão são empresas do setor industrial. No Brasil, as tarifas de energia elétrica estão estruturadas em dois grandes grupos de consumidores: grupo A e grupo B. As do grupo A são para consumidores atendidos pela rede de alta tensão, de 2,3 kV ou mais e são classificadas com letras e algarismos indicativos da tensão de fornecimento, sendo subdivididos em: A1, A2, A3, A3a, A4 e $\mathrm{AS}^{25}$.

\footnotetext{
${ }^{25}$ Sistema subterrâneo
} 
A tensão para atender demanda neste trabalho é de $13.8 \mathrm{kV}$, valor mais utilizado dentro dos critérios de carga instalada e demanda contratada ou estimada, estabelecidas e informadas pelas concessionárias de energia elétrica. O uso de outro nível de tensão poderia ser adotado, entretanto, poderia acarretar custos adicionais e não traria um impacto significativo para este estudo (Portaria ANEEL 456/2000; Art. $6^{\circ}$ inciso II; combinado com Art $7^{\circ}$, Art $8^{\circ}$, Art $2^{\circ}$, inciso XXII; SENNA, 2011). Este nível de tensão se enquadra no subgrupo A4 que compreende as tensões entre 2,3 kV até $25 \mathrm{kV}$ (ANEEL, 2005).

No quadro 16 apresentam-se as maiores e menores tarifas residenciais vigentes no ano de 2008 (DIEESE, 2007) das principais concessionárias dadas em reais por kWh. Observa-se que entre a maior e a menor tarifa existe uma diferença de 76,2 \%. Esta diferença é devida aos custos não-gerenciáveis em que a empresa concessionária cobra do consumidor final como a compra de energia, encargos setoriais e encargos de transmissão mais os valores necessários à cobertura dos custos de pessoal, de material, de outras atividades vinculadas diretamente à operação e manutenção, custos de depreciação e remuneração dos investimentos realizados pela empresa para o atendimento do serviço. O quadro completo está no APÊNDICE A.

\begin{tabular}{|l|l|l|}
\hline \multicolumn{1}{|c|}{ Concessionária } & \multicolumn{1}{c|}{ Área de atuação } & \multicolumn{1}{c|}{ Valor Tarifa Residencial } \\
\hline \multirow{2}{*}{$\begin{array}{l}\text { Enersul } \\
\text { Cemig }\end{array}$} & Mato Grosso do Sul & 0,43364 \\
\cline { 2 - 3 } $\begin{array}{l}\text { Celtins } \\
\text { Cataguazes-Leopoldina } \\
\text { Coelba }\end{array}$ & Minas Gerais & 0,43315 \\
\cline { 2 - 3 } $\begin{array}{l}\text { Light } \\
\text { Copel }\end{array}$ & Tocantins & 0,42854 \\
\cline { 2 - 3 } CEB & Parte de Minas Gerais & 0,41928 \\
\hline Eletropaulo & Parte do Rio de Janeiro & 0,36964 \\
\hline
\end{tabular}

QUADRO 16 - Tarifas Residenciais Vigentes até 2008 - Principais Concessionárias

DIEESE (2007) 
No Quadro 17 apresentam-se diversos valores em kWh para várias classes de consumo nas diferentes regiões do país retirados do site da ANEEL (2011a). No caso estudado, o preço do kWh utilizado pela distribuidora foi fixado em $\mathrm{R} \$ 0,2428$. Este valor é baseado nas médias das tarifas da classe de consumo industrial da região sudeste para o ano de 2009. Ele não se altera em função da aplicação de tarifas diferenciadas de consumo ou de demanda de potência de energia elétrica a consumidores industriais, ou conforme o horário de utilização do dia, ou períodos do ano.

\begin{tabular}{|c|c|c|c|c|c|c|}
\hline Classe de Consumo & $\begin{array}{l}\text { Centro } \\
\text { Oeste }\end{array}$ & Nordeste & Norte & Sudeste & Sul & Média \\
\hline Residencial & 0,2864 & 0,2838 & 0,3039 & 0,3008 & 0,2786 & 0,2907 \\
\hline Industrial & 0,2141 & 0,2146 & 0,2565 & 0,2428 & 0,2165 & 0,2289 \\
\hline $\begin{array}{l}\text { Comercial, Serviços e } \\
\text { Outros }\end{array}$ & 0,2732 & 0,2986 & 0,3213 & 0,2829 & 0,2573 & 0,2867 \\
\hline Rural & 0,2050 & 0,2101 & 0,2343 & 0,2001 & 0,1627 & 0,2024 \\
\hline Poder Público & 0,2825 & 0,3259 & 0,3473 & 0,3041 & 0,2812 & 0,3082 \\
\hline Iluminação Pública & 0,1568 & 0,1779 & 0,1784 & 0,1636 & 0,1449 & 0,1643 \\
\hline Serviço Público & 0,1801 & 0,1997 & 0,2254 & 0,2126 & 0,1897 & 0,2015 \\
\hline Consumo Próprio & 0,3027 & 0,3103 & 0,3344 & 0,2954 & 0,2395 & 0,2965 \\
\hline Rural Aquicultor & 0,2339 & 0,1648 & 0,2333 & 0,1762 & 0,0763 & 0,1769 \\
\hline Rural Irrigante & 0,1397 & 0,1417 & 0,1685 & 0,2064 & 0,1233 & 0,1559 \\
\hline
\end{tabular}

QUADRO 17 - Preço da Energia em kWh

Adaptado de ANEEL (2011a)

\subsection{4 - Custo para interligar o sistema à rede}

Os custos existentes para a expansão da rede de distribuição de energia foram extraídos de publicações da área. Segundo o artigo de Ribeiro et al. (2000), os custos estão entre $\mathrm{R} \$ 11.950,00$ e $\mathrm{R} \$ 13.860,00$ por quilometro de rede. Para utilizar estes valores fez-se uma média e atualizou-se este valor para o ano de 2010 pelo índice IPCA, de 2000 a 2010, em 101,18\%, (BCB, 2011), resultando no valor de R\$25.962,73 por quilometro de rede instalada. Este valor foi comparado a projetos da área que o corroboram. 
O custo da mão de obra por poste/ano segundo Brito e Castro (2007) varia para áreas arborizadas e não arborizadas, e entre diferentes tipos de redes. Pode-se considerar uma média de 153,00 dólares por poste/ano.

Considerando-se 6,5 postes por quilometro, uma taxa de câmbio a R \$1,70 (valor médio de 2010), mais uma atualização pelo IPCA de 2007 a 2010 de 22,2\% chega-se a um valor de R\$2.066,17 de custo para o quilometro/ano para a mão de obra. Este valor considera a soma das correções preventivas e corretivas para os diferentes tipos de redes de distribuição.

\subsection{5 - Características das Fontes Disponíveis}

Para estes estudos verificaram-se as características geográficas e climáticas do local desejado para implantação de um determinado sistema, já que variações locais podem interferir em suas características de operação. A cidade de São Paulo foi escolhida como a região base da modelagem. Assim, os dados obtidos para os fenômenos climáticos e outras informações tiveram esta cidade como referência.

As condições de radiação solar e as condições de vento variam de acordo com a longitude, latitude, altitude e proximidade do mar. Lugares mais próximos do equador apresentam uma radiação maior. Nas localidades litorâneas a velocidade média dos ventos é superior àquela de cidades não litorâneas.

Os valores de velocidade média de ventos e de intensidade da radiação solar de São Paulo foram obtidos através do banco de dados do RETSCREEN (2011).

No gráfico 10 apresenta-se um gráfico da velocidade média do vento em m/s na cidade de São Paulo. Estes dados foram utilizados na modelagem, para calcular a potência produzida pelo gerador eólico: 


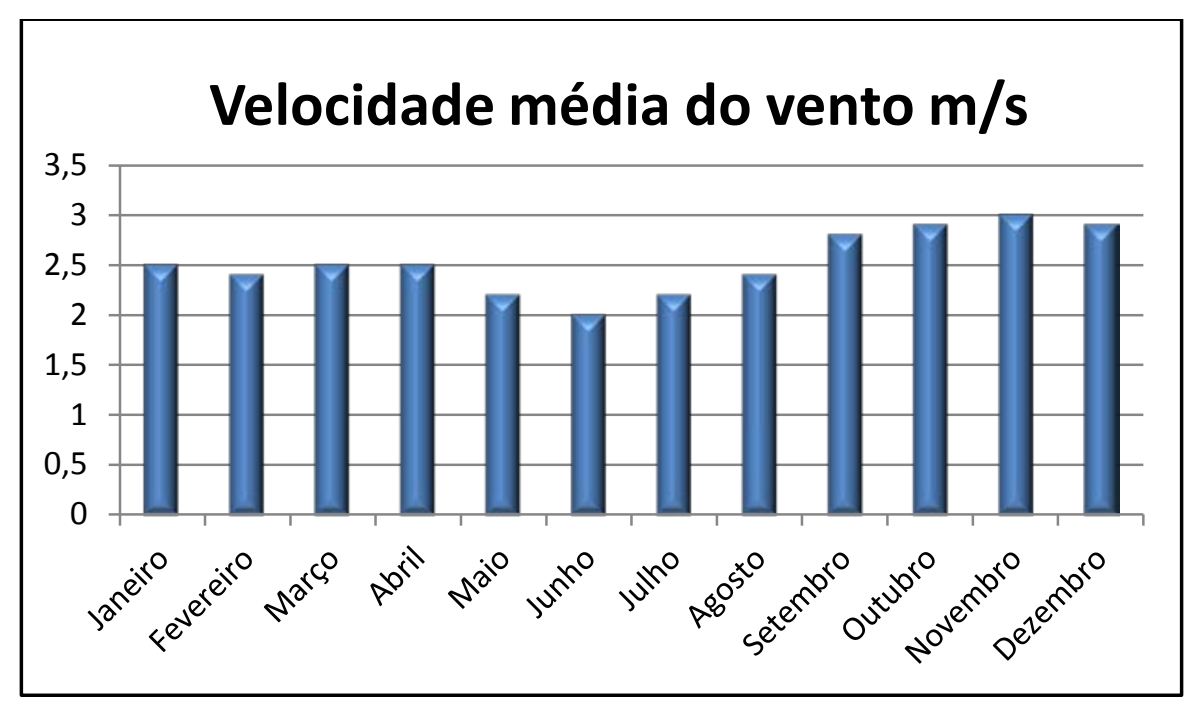

GRÁFICO 10 - Média de velocidade de vento em São Paulo

RETSCREEN, 2011

Os valores da radiação solar foram recolhidos de 1983 a 1993 e tem entre 20 a 25\% de incerteza (NASA, 2009). O RETscreen recolhe informações da NASA e de outros parceiros locais e os armazena em seu banco de dados. No gráfico 11 apresentam-se dados da intensidade da radiação solar na cidade de São Paulo, também inseridos no sistema.

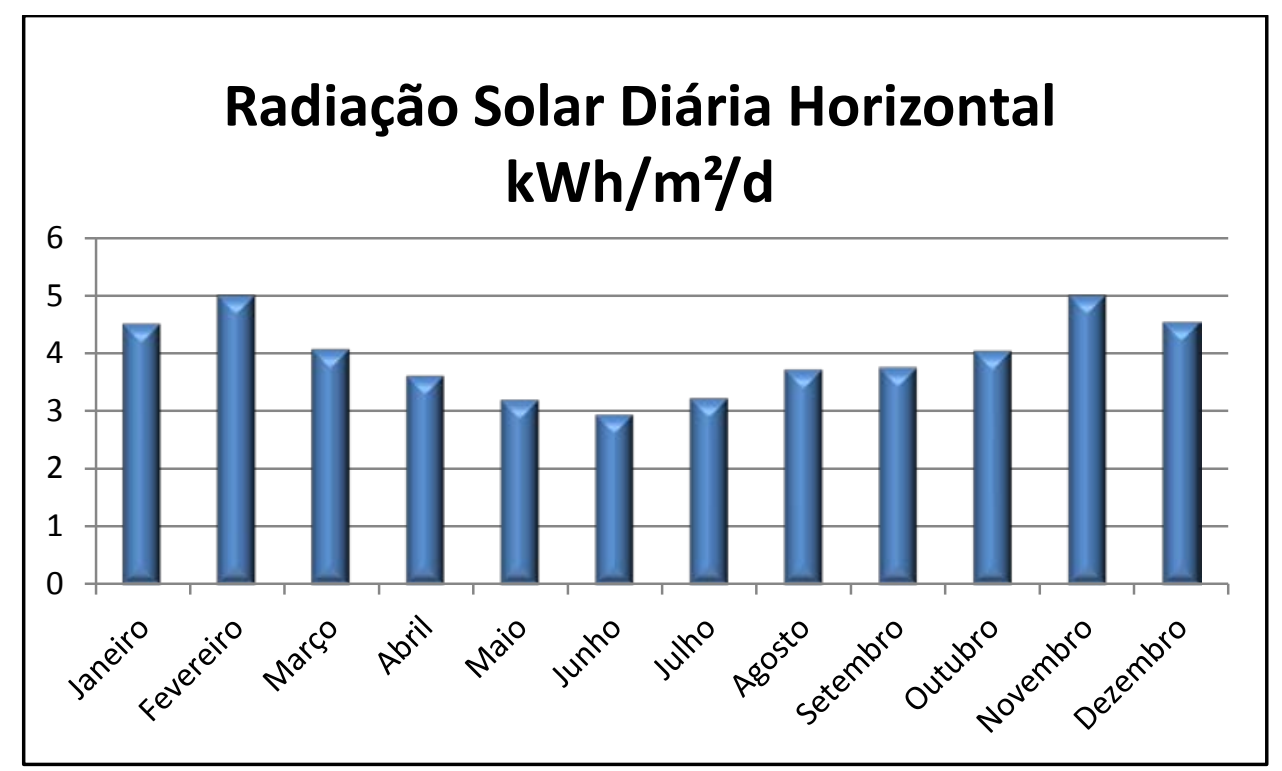

GRÁFICO 11 - Média da Radiação Solar em São Paulo RETSCREEN, 2011 


\subsection{6 - Custos das Unidades Geradoras e outros equipamentos}

\subsubsection{1 - Célula a Combustível}

Para se determinar qual tipo e marca de célula a combustível seria utilizada no estudo foram pesquisados vários modelos disponíveis no mercado, como nas empresas Ballard, Fuel Cell Energy, Hidrogenics, IdaTech, Medis, mtimicro, Nuvera, plugpower, ReliOn, UltraCell e UTC Power.

Escolheu-se uma Célula a Combustível (CC) de ácido fosfórico (PAFC) para a simulação, pois esta se mostra mais adequada para aplicações estacionárias com a faixa de potência de $250 \mathrm{~kW}$, que corresponde a faixa escolhida para este estudo, além da sua maior disponibilidade no mercado.

O modelo escolhido foi o PC25C da UTC, ajustado na simulação para oferecer $250 \mathrm{~kW}$ ou invés dos usuais $200 \mathrm{~kW}$, que apresenta uma eficiência de $42 \%$ no início da operação e 35\% ao final. A vida útil de operação deste modelo pode chegar a 60.000 horas. (LINARDI, 2010b, p. 88 - 89)

Para Remick e Wheeler (2009), em curto prazo não foi identificado um caminho claro para a diminuição de custos para valores abaixo de US\$2.000/kW nas células PAFC. Para a comissão de energia do estado da Califórnia, o valor do kW para células MCFC e SOFC estará em 1.500 dólares, a longo prazo.

No presente, alguns autores identificam que a diminuição de custos está relacionada a dois fatores. Primeiro aos avanços de projeto físico na fabricação, e o segundo resultante de aumento da densidade de potência nas membranas das unidades geradoras. No momento, a PAFC tem o preço médio de US\$3.000,00 por $\mathrm{kW}$ nos EUA.

Para os cálculos utilizados, atualizou-se o valor do dólar a uma taxa de câmbio de $\mathrm{R} \$ 1,70$ e chegou-se a um custo de $\mathrm{R} \$ 5.100,00$ por kW. Como a potência exigida é $250 \mathrm{~kW}$ temos um custo de R\$1.275.000,00. 
O custo de manutenção das células a combustível é muito baixo, menos de $\mathrm{R} \$$ 0,10 por hora de operação, pois se baseia no custo de uma visita de inspeção trimestral para a unidade, mais limpeza e lubrificação (DER, 2002; PARANHOS et al. 2002) e portanto tem pouco impacto nos cálculos. O custo do Hidrogênio foi estabelecido em R\$ 15,00 o metro cúbico (PORTAL, 2006).

\subsubsection{2 - Gerador Eólico}

Utilizou-se a usina Eólio-elétrica experimental do Morro do Camelinho como referência, citada nos estudos de Camargo (2005) e Lisboa (2010). A altura da torre é de 30 metros e seus rotores possuem 21 metros de diâmetro. A turbina é produzida pela Tacke Windtechnick - Alemanha e seu tempo de vida foi estimado em 20 anos. Escolheu-se esta unidade geradora pelas características como potência máxima de operação e acesso aos dados de custos.

A curva de potência do gerador eólico, cuja potência varia em relação à velocidade do vento, está mostrada no gráfico 12. Observa-se que ela tem sua potência máxima a uma velocidade de vento em 15 m/s:

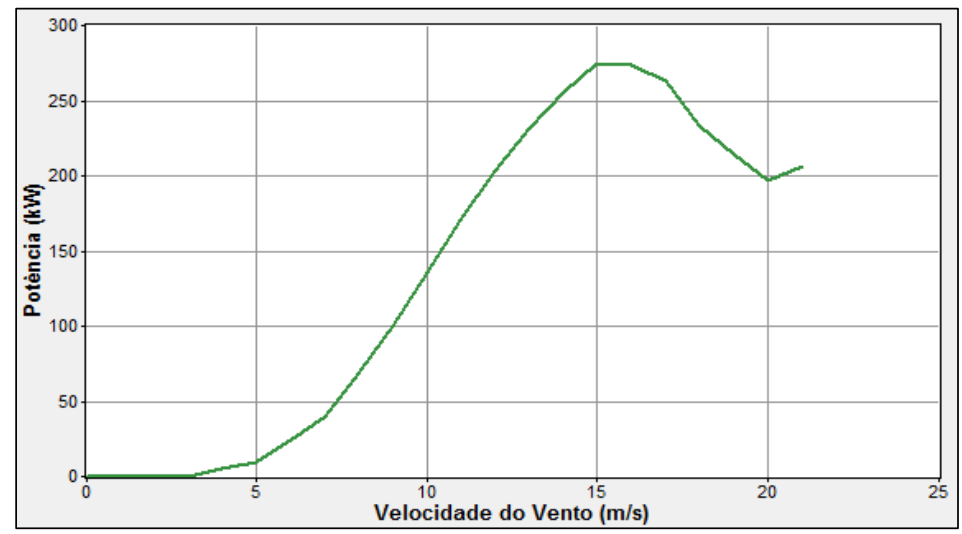

GRÁFICO 12 - Caracterização da potência por velocidade de vento do Gerador Eólico Adaptado pelo autor a partir de dados fornecidos pela CEMIG 1998 apud CAMARGO 2005 
O valor de instalação total foi calculado em 385.000,00 dólares por gerador eólico. Com a cotação do dólar a $\mathrm{R} \$ 1,70$, o valor resultante foi de $\mathrm{R}$ \$ 654.500,00. O custo de operações e mão de obra ao ano foi estimado em 3\% aproximadamente, resultando em um valor de $\mathrm{R} \$ 19.635,00$.

Pode-se observar que nem sempre o local de maior custo de instalação é o menos indicado, pois caso a velocidade e características do vento forem mais favoráveis nessa área, haverá uma compensação deste custo. Assim sendo, este novo local poderá ser o escolhido para a implantação do gerador.

\subsubsection{3 - Gerador Hídrico}

A turbina simulada foi um modelo BANKI - adequado para o volume de vazão e potência pesquisado. Este tipo de turbina possui uma eficiência em torno de 75\%. O desnível é de 34 metros para um volume de água de 1000 L/s. O duto de adução possui 80 metros de comprimento e 700 milímetros de diâmetro. Considerou-se uma perda de eficiência de 1,45\% devido à tubulação metálica e às características físicas do duto. A vida útil da usina foi considerada como 20 anos, abaixo dos 25 anos normalmente utilizados neste tipo de gerador, mas adequado as características do estudo.

Na geração hídrica foram considerados os seguintes custos: turbina hidráulica, válvula borboleta, conduto forçado, grade, comporta de tomada d'água, montagem eletro-mecânica, obras civis e despesas de manutenção e operação, baseando-se no trabalho de Bettarelo (2010).

O valor total do investimento obtido correspondeu a um valor muito próximo de R\$ 500.000,00 para uma potência de 250kW. O custo de manutenção e operação calculado foi da ordem de $\mathrm{R} \$ 4.600,00$ por ano durante os 20 anos de operação. 


\subsubsection{4 - Geração Solar}

As características técnicas e econômicas da Geração Solar serão discutidas nos Resultados por sua peculiaridade.

\subsubsection{5 - Grupo Moto Gerador Diesel (GMG)}

Estudou-se a influência da potência do gerador no custo do sistema e da energia. A potência deste grupo gerador neste estudo está na faixa de $313 \mathrm{kVA} / 250 \mathrm{~kW}$. O gerador a Diesel tem uma vida útil de operação de no mínimo 20.000 horas (LAMBERT, 2004).

Utilizou-se o Diesel como combustível e uma tarifa básica variando em torno de R\$ 2,00. O custo do Diesel foi considerado como um valor médio cobrado nos postos de combustível da cidade de São Paulo em dezembro de 2010. Este valor central foi extraído do banco de dados da Agência Nacional do Petróleo, Gás Natural e Biocombustíveis (ANP, 2010).

O preço de aquisição mais instalação foi calculado em R\$ 156.200,00. Este valor foi calculado através de uma média ponderada dos valores observados nos trabalhos de Succar, 2008; Saraiva, 2011; Soares et al., 2000 além de orçamento realizado na $\mathrm{PINI}^{26}, 2011$.

O custo de operação e de manutenção foi obtido no artigo de Soares et al. (2000) e atualizou-se este valor para o ano de 2010 pelo índice IPCA, de 2000 a 2010, em 101,18\%. Chegou-se a um valor de R \$ 1,23 por hora de operação.

\footnotetext{
${ }^{26}$ A tabela de preços PINI é inspirada na tabela de preços da MasterFormat adotada pelos EUA, Canadá e países europeus, possibilitando que os insumos sejam estruturados segundo a lógica de bancos de dados e comparados no ambiente de comércio eletrônico.
} 


\subsubsection{6 - Inversor}

A conversão da corrente contínua produzida por um banco de bateria ou pela célula a combustível para corrente alternada é feita por um inversor. Este inversor tem eficiência de 92\% de conversão e de $85 \%$ de eficiência de retificação da corrente, o que naturalmente faz com que os equipamentos com saída em corrente contínua percam em eficiência em relação ao preço da energia produzida.

O orçamento de um inversor com uma alimentação de 380-500 Vac, de potência de $228 \mathrm{~kW}$ e em que a corrente nominal do motor não ultrapasse $375 \mathrm{~A}$, o que atende a este estudo, foi de $\mathrm{R} \$ 34.000,00$.

\subsubsection{7 - Banco de baterias (12MP400)}

Fez-se simulação desta etapa com ausência total de baterias e considerando-se grupos de cinco, dez e quinze unidades. Considerou-se uma configuração da bateria de $12 \mathrm{~V}, 400 \mathrm{Ah}, 4.8 \mathrm{kWh}$. Para uma simulação mais realista modelou-se a bateria de acordo com a descarga de corrente. Este dado foi encontrado no manual da fábrica brasileira MAX POWER, que manufatura estes dispositivos. A vida útil da bateria foi considerada de 4 anos.

De acordo com o orçamento realizado, cada bateria saiu a um preço de R\$ 700,00 mais um valor unitário médio de R\$ 20,00 para a estante de acomodação. 


\subsubsection{8 - Quadro Resumo dos Custos e Operação}

No quadro 18 apresenta-se o resumo dos valores para os custos de instalação e de manutenção das Unidades Geradoras e outros equipamentos:

\begin{tabular}{|c|c|c|}
\hline Equipamento & $\begin{array}{c}\text { Custos de implantação em } \\
\mathrm{R} \$ \text { (valor unitário) }\end{array}$ & Custos de Operação em R\$ \\
\hline Célula a Combustível & $1.275 .000,00$ & Custo Hidrogênio $+0,10 \mathrm{p} /$ hora \\
\hline Gerador Eólico & $654.500,00$ & $19.635,00$ por ano \\
\hline Gerador Hídrico & $500.000,00$ & $4.600,00$ por ano \\
\hline GMG & $156.200,00$ & $1,23 \mathrm{p} /$ hora \\
\hline Inversor & $34.000,00$ & Não aplicado \\
\hline Banco de baterias & 720,00 & Não aplicado \\
\hline
\end{tabular}

Quadro 18 - Resumo dos valores para os custos de instalação e de manutenção 


\section{RESULTADOS E DISCUSSÃO}

Neste trabalho analisou-se a viabilidade técnica e econômica de um sistema híbrido sustentável de energia por meio do programa HOMER, onde se fizeram simulações com diversas configurações de sistemas híbridos de geração de energia.

Nestas simulações os parâmetros de entrada foram usados para estimar todos os resultados apresentados nos tópicos seguintes.

Para o cálculo final das possibilidades foram feitas 1600 simulações em 3500 análises de sensibilidade válidas, totalizando 5,6 milhões de resultados analisados.

Os resultados deste trabalho dependem diretamente da metodologia utilizada e das hipóteses assumidas. Todos os resultados quantitativos estão sujeitos a incertezas decorrentes da previsão dos cenários econômicos, políticos e ambientais projetados para o futuro. Além disso, essas incertezas tendem a ser acentuadas no caso do desenvolvimento de novas tecnologias. Por isto os resultados deste trabalho não podem ser aplicados fora do universo estudado sem uma análise criteriosa do seu uso.

\subsection{Sistema}

Considerou-se, como modelo, um sistema isolado desconectado da rede. Ele foi composto de Geradores Eólicos; Gerador Hidroelétrico (MCH); Gerador Diesel (GMG); Célula a Combustível; Banco de Baterias (12MP400) e Inversor.

O projeto do sistema híbrido para geração da energia foi modelado no software e a configuração considerada para o atendimento da carga é mostrada na figura 01. A demanda é representada pelo ícone lâmpada e simboliza o consumidor, com dados da demanda diária e a potência máxima exigida do sistema, as setas representam o fluxo da corrente, e AC e DC são respectivamente corrente alternada e corrente contínua: 


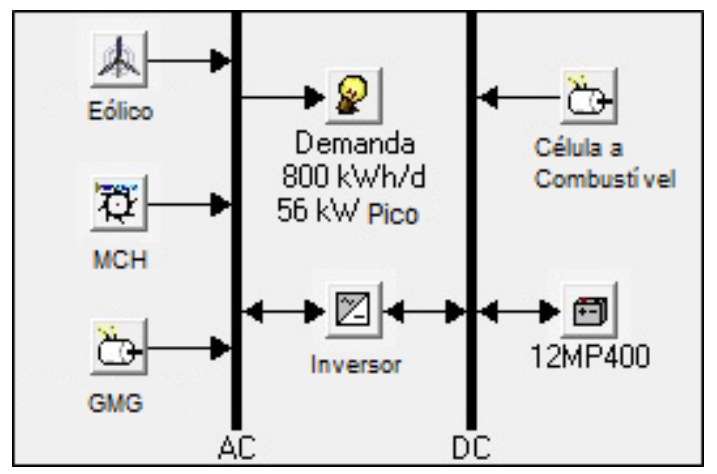

FIGURA 01 - Representação do Sistema Híbrido para geração de eletricidade

Com o objetivo de se estabelecer uma comparação entre as unidades geradoras de energia para um centro consumidor de energia analisou-se a possibilidade de cada unidade funcionar separadamente ou em conjunto, de forma simultânea ou complementar.

A melhor condição técnica será aquela em que os equipamentos funcionam adequadamente atendendo a demanda ao menor custo. Levou-se em conta que o sistema deveria suprir a demanda definida sem deixar uma demanda não atendida.

Observa-se ainda que na figura 01 a unidade de geração solar não está presente. Ela foi descartada do modelo final após as primeiras simulações, pois notou-se dois problemas para este estudo. O primeiro é que o espaço físico ocupado pelos painéis solares para atender a demanda estabelecida do sistema teria que ser uma área muito maior do que normalmente a indústria tem disponível. O segundo é relativo ao custo desta tecnologia.

Uma placa solar comercial hoje em dia pode produzir em média um pouco mais de $100 \mathrm{~W}$ por metro quadrado. Para um sistema de $250 \mathrm{~kW}$ de potência seriam necessários 2.500 metros quadrados de área para instalação, o equivalente a aproximadamente meio campo de futebol. Este espaço deverá ser aproximadamente o dobro ao se considerar que a placa solar só opera durante o dia para acumulação de carga. Este é um espaço grande demais para a maior parte das instalações que necessitam desta ordem de potência.

O segundo fator é o alto custo dos painéis solares da ordem de R\$15.000,00 o kW (Célula Solar Fotovoltaica Monocristalino) e, por este motivo, não seriam incluídos 
em nenhuma configuração ótima em nenhum dos cenários propostos. Assim pode-se descartar totalmente a viabilidade técnica e econômica do sistema solar, dadas as condições deste trabalho. Ressalta-se que para outras condições fora do escopo deste trabalho o uso da energia elétrica solar poderá ser viável.

\subsection{Cálculo do Valor Presente Líquido por sistema estudado}

No gráfico 13 apresentam-se os valores presentes líquidos, com o menor custo, para diferentes tipos de geração/sistemas híbridos. Ao apresentar os melhores resultados, que correspondem às diferentes configurações do sistema, está subentendido o menor número de equipamentos que irá suprir a demanda.

Foram estabelecidas como condições uma velocidade de vento a 2,6 m/s, fluxo de água a $1000 \mathrm{~L} / \mathrm{s}$, Diesel a R\$2,00/L e Hidrogênio a R\$15,00/m³.

O valor para cada sistema foi dado pela soma do valor presente de cada componente com o valor presente de todos os custos de instalação, menos o valor presente de todas as despesas, inclusive as de operação, que se obtém ao longo da duração do projeto. Os resultados são apresentados em ordem crescente de valores, tendo sido encontrado o sistema hídrico como o de melhor avaliação.

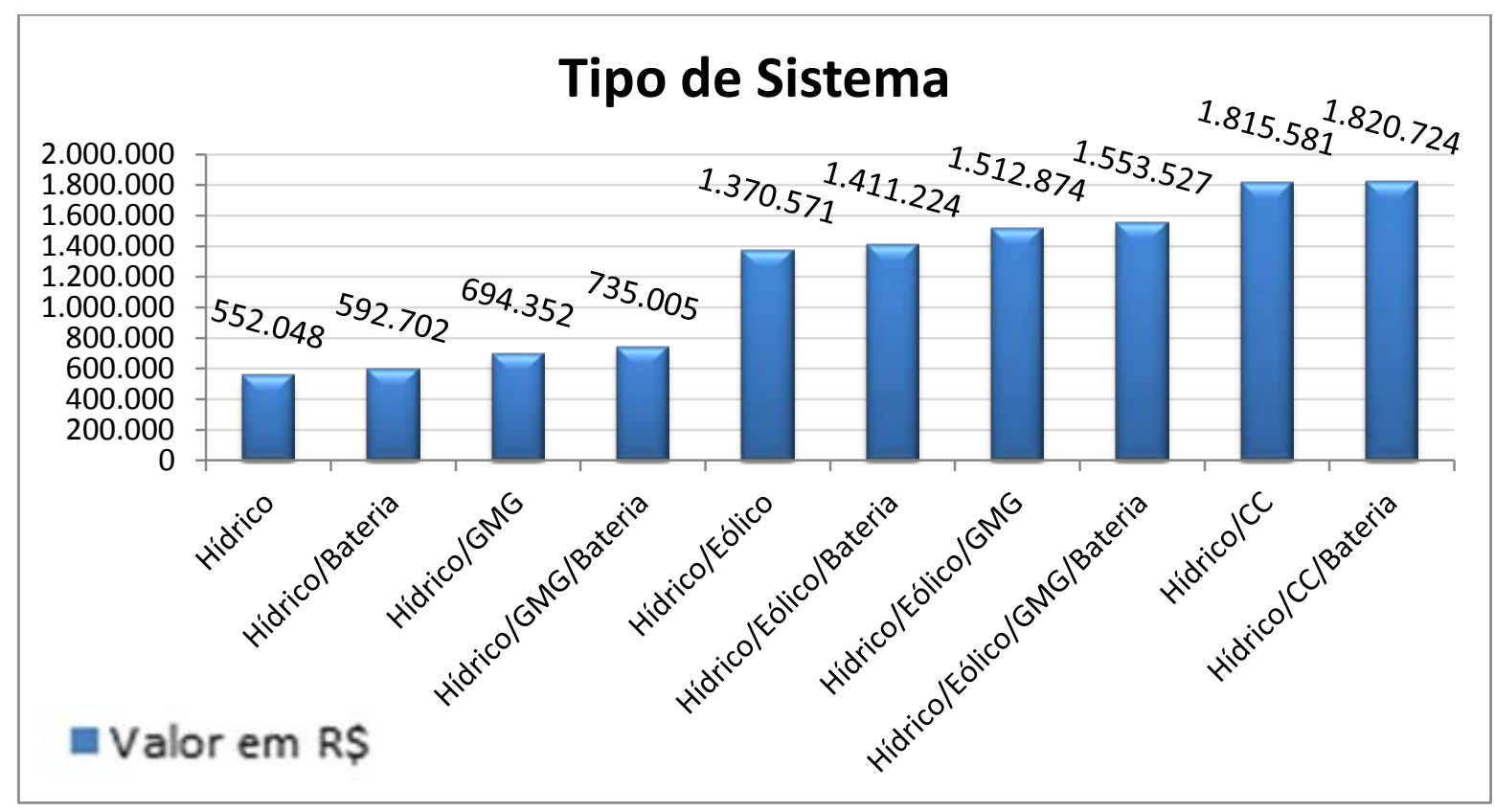


GRÁFICO 13 - Valor Presente Líquido por tipo de sistemas

Para a arquitetura de menor VPL, o hídrico, encontrou-se o valor de R\$ 552.048,00 - equação (1), e um custo da energia (COE) de R\$ 0,2750/kWh, de acordo com a equação (4), o que representa um valor ligeiramente maior que a compra da eletricidade da rede para a maior parte das aplicações.

Considerando apenas a tarifa média adotada pelas fornecedoras de energia do sudeste, para consumo industrial, de R \$ 0,2428 (vide 4.3.3 - quadro 17), ou para média nacional de R\$ 0,2289 (idem), sem os custos de ampliação da rede de distribuição, não é vantajoso a implantação das unidades geradoras distribuídas se compararmos um COE ao outro.

Para algumas aplicações este sistema pode ser vantajoso. É o caso do consumo residencial como condomínios, para uso no comércio e serviços, do poder público, em todas as regiões brasileiras (vide 4.3.3 - quadro 17) ou para algumas concessionárias do país. (APÊNDICE A)

Além da comparação direta dos COE deve-se considerar que para alguns grupos consumidores a energia elétrica da rede não está disponível sem uma ampliação do sistema de distribuição, que efetivamente tornará a energia fornecida pela concessionária mais onerosa. Por este motivo esta diferença entre os custos são discutidos no item: Sistema autônomo x Custo de ampliação da rede.

O cálculo do VPL considerou o valor do investimento inicial e seu custo de operação. Em consequência, permitiu comparar as alternativas de investimentos e estabelecer uma ordem de preferência e uma ordem métrica, para indicar quanto uma alternativa é mais atrativa que outra em termos financeiros. Essas características fazem do VPL a medida de valor mais aceitável para tomada de decisão em investimentos, sendo a que melhor descreve o custo do investimento, portanto a mais consistente em considerar a maximização do lucro para a tomada de decisão. 


\subsection{Sistema autônomo x Custo da ampliação da rede}

No gráfico 14 ilustra-se a comparação do custo do sistema autônomo baseado no Hídrico, de menor custo, com o custo da ampliação da rede para atender a carga, de acordo com a expressão (5).

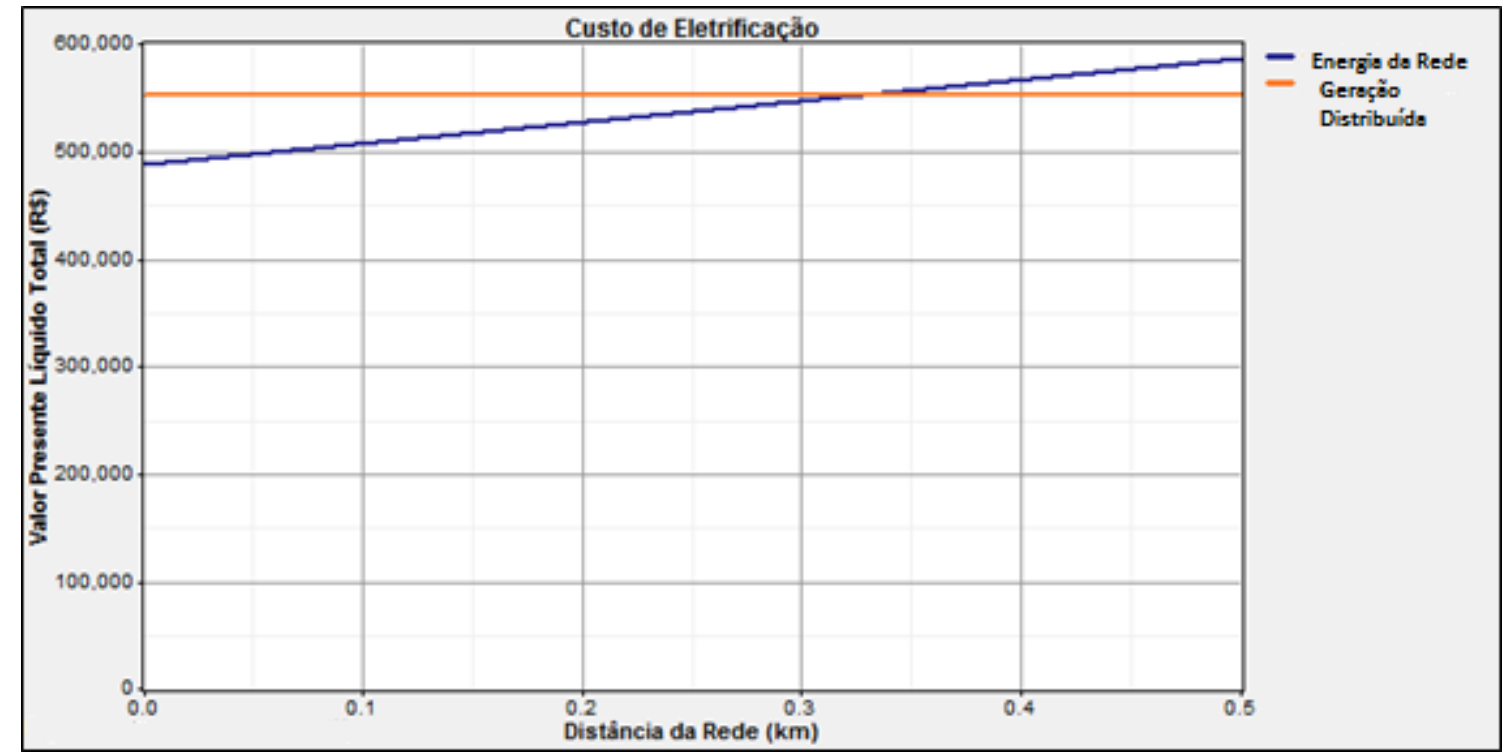

GRÁFICO 14 - Comparação de custo entre o Gerador Hídrico e o de ampliação da rede

O valor de 325 metros (onde as retas se cruzam) foi encontrado como o ponto de equilíbrio da rede e indica onde o valor presente líquido de ampliação da rede é igual ao valor presente líquido do sistema autônomo. Abaixo deste valor é mais vantajoso adotar-se o sistema da concessionária e acima o gerador Hídrico.

No gráfico 15 buscou-se a comparação do custo do sistema híbrido Hídrico/ Banco de Baterias (BB) com o custo da ampliação da rede para atender a carga de acordo com o modelo anterior. 


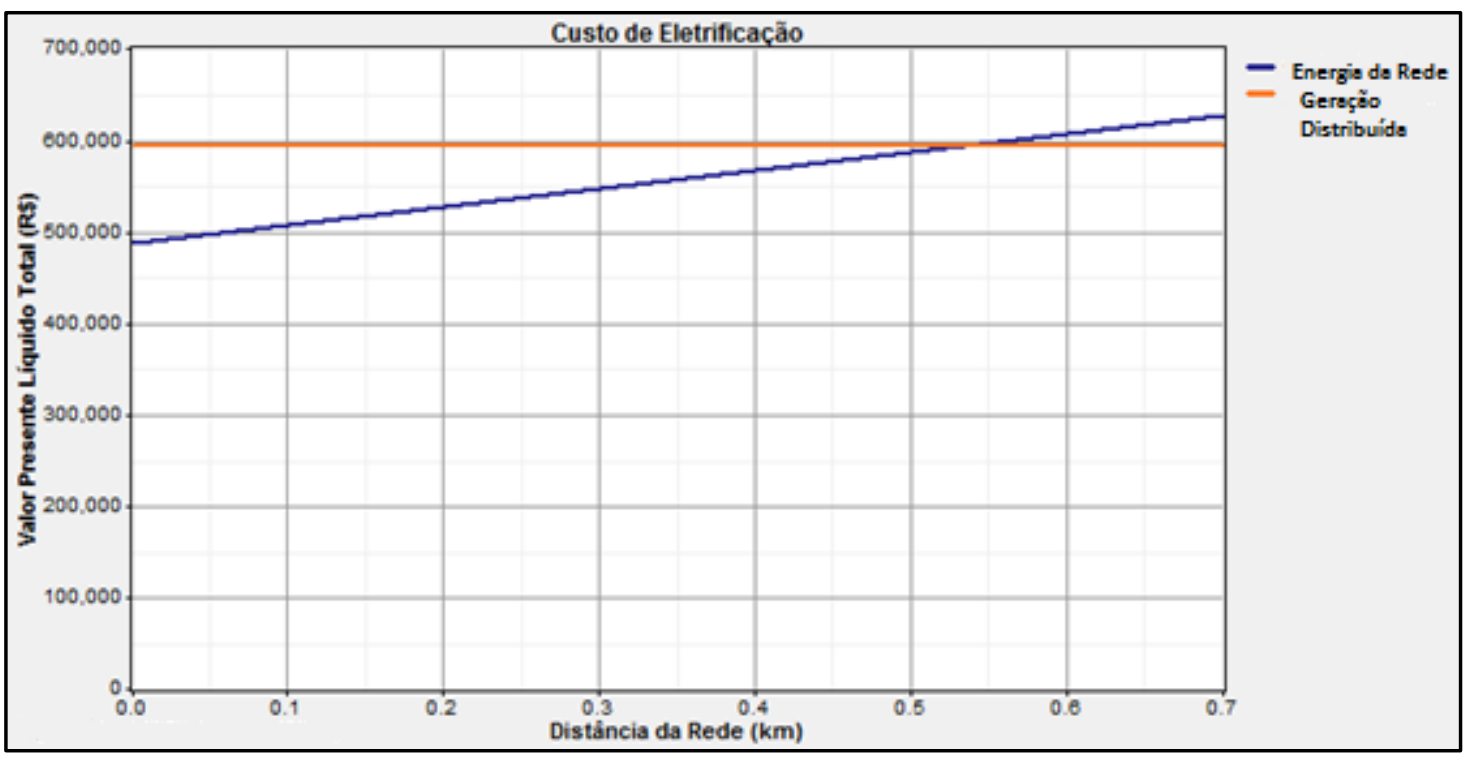

GRÁFICO 15 - Comparação de custo entre o Sistema híbrido ‘Hídrico/BB’ e o da rede

O valor de 528 metros foi encontrado como o ponto de equilíbrio da rede, ou seja, até 528 metros é preferível optar pela ampliação da linha de suprimento recebendo assim energia da concessionária. Observa-se que quanto maiores os custos do sistema autônomo maior é a distância que a rede de distribuição poderá ser construída até o consumidor.

\subsection{Cenários}

O termo cenário pode ser entendido de maneiras diferentes. Os militares, por exemplo, consideram os cenários como planejamentos de contingência para uma gama de eventualidades. Os probabilísticos os constroem a partir da combinação de diversas variáveis críticas, utilizando modelagens matemáticas. Neste estudo a otimização selecionou o resultado de inúmeras simulações apontando para os de melhores características. Similarmente, a análise de sensibilidade interpolou múltiplos valores sobre os sistemas selecionados pela otimização. Os resultados são apresentados nos diferentes cenários estudados através de gráficos que buscam mitigar os efeitos da incerteza. 
Quando a análise envolve mais de uma variável de sensibilidade, um gráfico traz os resultados de uma forma mais significativa do que uma tabela consegue. O gráfico do Tipo de Sistema Ideal - Optimal System Type (OST) fornece uma visão de alto nível dos resultados de sensibilidade. Ele mostra o menor custo do sistema em relação a duas variáveis escolhidas para análise de sensibilidade. As diversas cores do gráfico faz com que seja mais fácil ver em que condições os diferentes tipos de sistemas são os ideais.

\subsection{1 - Todas Unidades Geradoras}

Para análise da sensibilidade variou-se simultaneamente a velocidade do vento e a vazão de água. A velocidade do vento foi simulada de 0 a $25 \mathrm{~m} / \mathrm{s}$ e a vazão de água de 0 a 1000 litros por segundo. O preço do diesel foi fixando em R 2,00. O gráfico 16 ilustra estas condições com todas unidades geradoras disponíveis para geração elétrica.

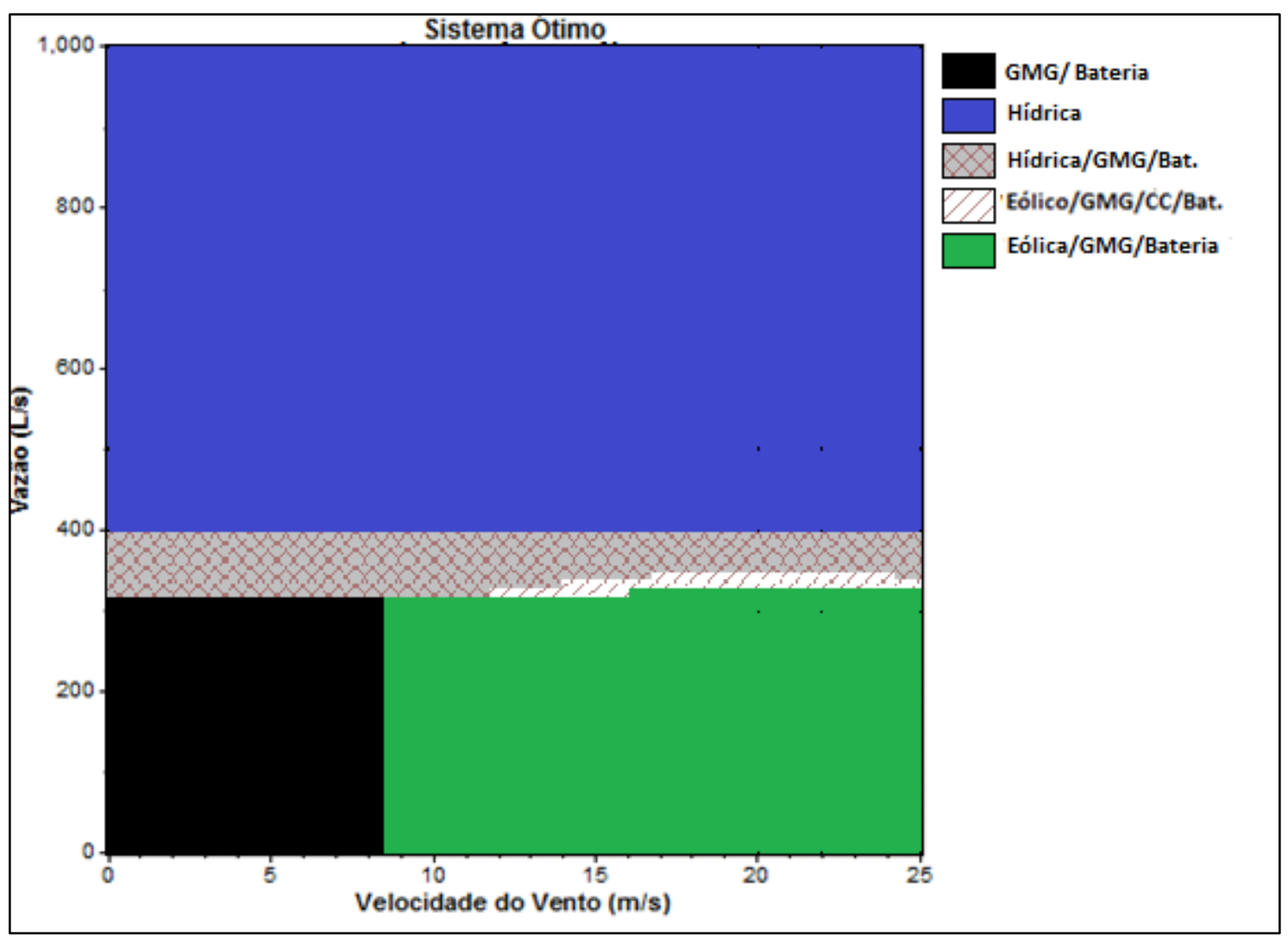

GRÁFICO 16 - Cenário 1: Todas Unidades Geradoras 
O resultado que obtivemos em uma velocidade de vento de 0 a $8,5 \mathrm{~m} / \mathrm{s}$ até aproximadamente $300 \mathrm{~L} / \mathrm{s}$, na cor preta, é a faixa onde o Gerador Diesel associado a um banco de baterias (BB) possui o menor VPL, isto é, a faixa de operação em que ele deve ser escolhido.

De $8,5 \mathrm{~m} / \mathrm{s}$ até $25 \mathrm{~m} / \mathrm{s}$ em verde, a utilização de um sistema híbrido Eólico/Diesel/BB teria maior vantagem. Acima, em curva, em uma estreita faixa em cinza tracejado, a utilização do sistema Hídrico/Diesel/BB. A faixa entre 300 a 400 L/s, em branco representa a escolha de um sistema Hídrico/Eólico/Diesel/BB. Acima de 300L/s o sistema Hídrico está presente em qualquer configuração e acima de $400 \mathrm{~L} / \mathrm{s}$ em azul este sistema autônomo é o mais efetivo.

A célula a combustível neste cenário não obteve nenhuma faixa onde obteve o menor custo.

\subsection{2 - Sem o Sistema Hídrico}

Nesta análise de sensibilidade excluiu-se o sistema Hídrico das unidades geradoras, já que ficou evidente a escolha deste tipo de sistema caso as condições de vazão do local a ser construído, lhe permitirem implantá-la.

No gráfico 17 mostra-se o resultado da variação do preço do Diesel em relação à velocidade do vento. Percebe-se que sem vento até uma velocidade em torno de $3 \mathrm{~m} / \mathrm{s}$ diminuindo até 13,5 m/s, o Gerador a Diesel em preto, é o mais vantajoso.

Outro ponto interessante possível de se observar é que somente com o Diesel a um preço acima de $\mathrm{R}$ \$10,50, aproximadamente, a célula a combustível em laranja, em funcionamento ‘stand-alone’ é viável comercialmente.

Através deste gráfico é possível perceber que com um diesel na faixa de R \$ 2,00 e com uma velocidade de vento superior a 14 m/s o sistema Eólico/Diesel/BB em verde, deve ser adotado. A partir de uma velocidade de vento na faixa de $20 \mathrm{~m} / \mathrm{s}$ e com o valor do Diesel acima de R\$ 6,00, deve-se adotar a célula a combustível entra como cogerador neste cenário. Acima de R\$10,00 o sistema Diesel deixa de ser viável para compor qualquer sistema. 


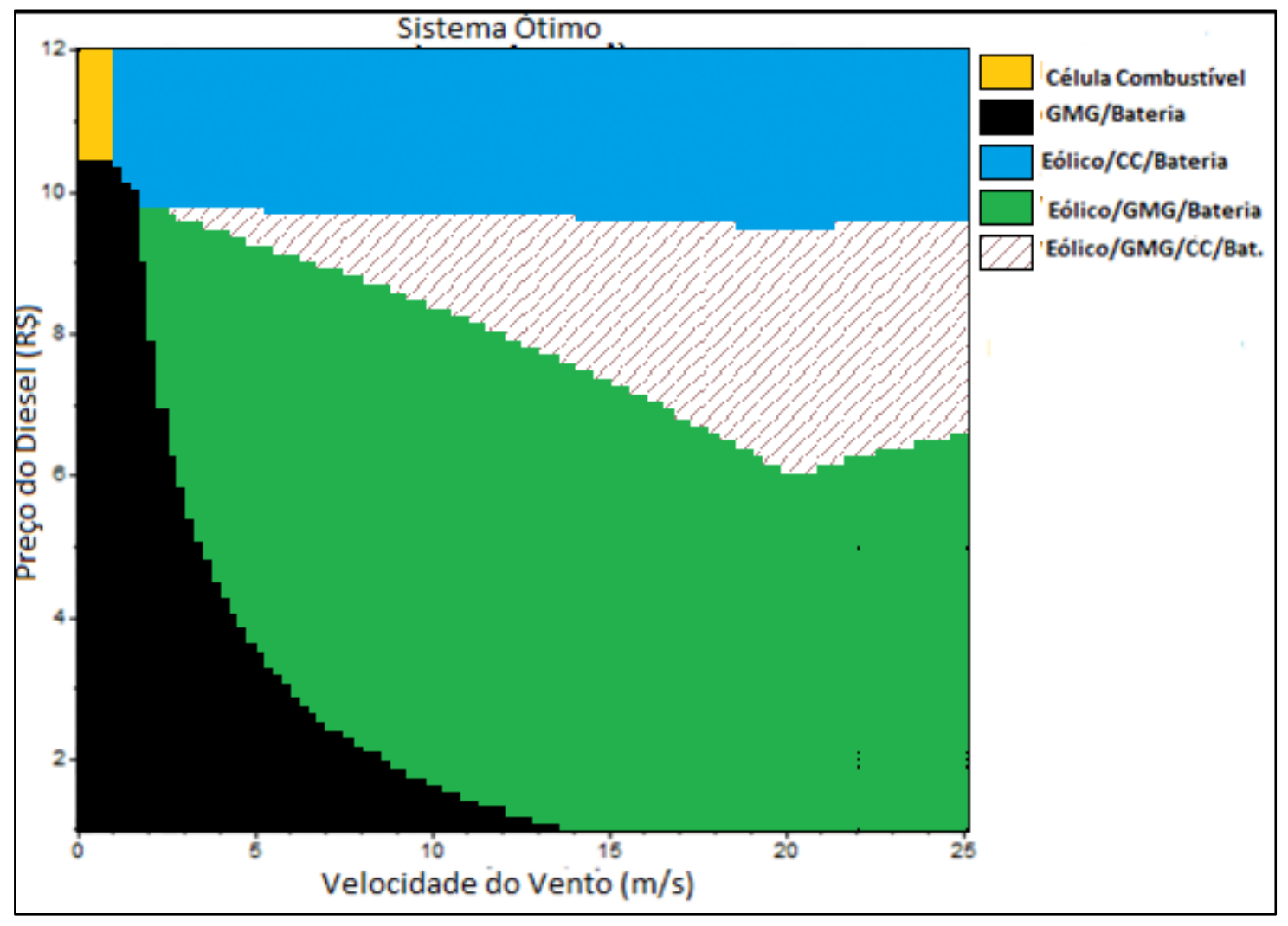

GRÁFICO 17 - Cenário 2: Sem o Sistema Hídrico

A célula a combustível é um gerador de alto custo de instalação, com um baixo custo operacional, por isto é desejável que ela opere em sua máxima capacidade, com o intuito de amortizar rapidamente o capital investido na sua instalação. Já um gerador a diesel tem baixo custo inicial e alto custo operacional, pois possui combustível e manutenção caros. Por isso, geradores a diesel são preferencialmente instalados para operações eventuais que exigem, de preferência, poucas horas de utilização.

\subsection{3 - Célula a Combustível x Gerador Eólico}

No gráfico 18 excluiu-se, além do gerador hídrico, o gerador diesel das possíveis escolhas dos sistemas para este cenário. O que se observa é a relação de duas opções: a célula a combustível operando em 'stand-alone’ e um sistema híbrido Eólico/célula a combustível/BB. 
Se o preço do hidrogênio se aproximar de zero, como é o caso de algumas aplicações industriais, deve-se adotar a Célula a Combustível como gerador para qualquer velocidade de vento.

Para uma velocidade de vento acima de $15 \mathrm{~m} / \mathrm{s}$ e um preço do hidrogênio a de 1,00 R \$ deve ser incluído um Gerador Eólico.

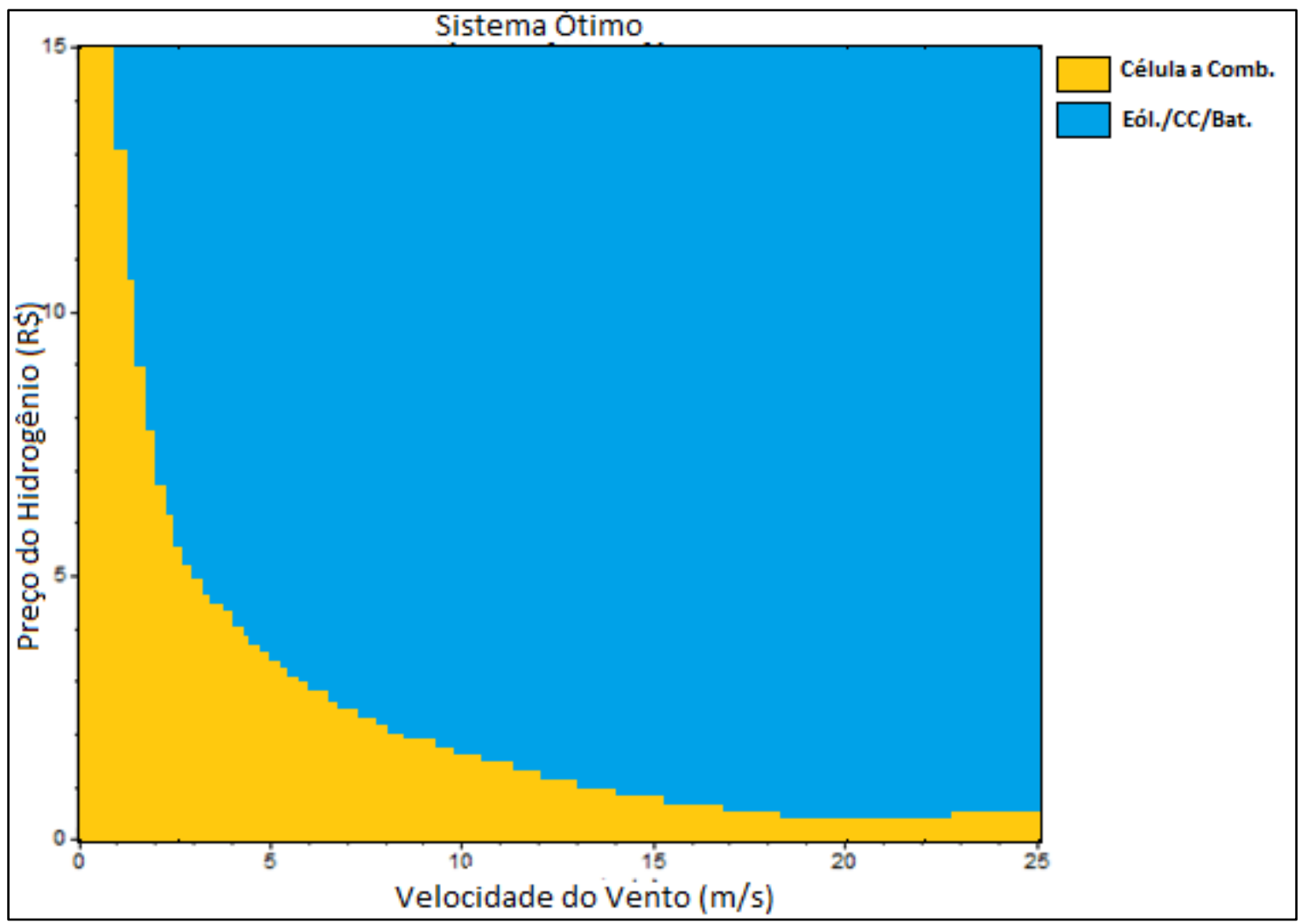

GRÁFICO 18 - Cenário 3: Célula a Combustível x Eólico

\subsection{4 - Célula a Combustível x Diesel}

No gráfico 19 mostra-se a aceitação da célula combustível, frente as demais unidades geradoras de energia renováveis, ainda sem o Gerador Hídrico.

Neste cenário o preço do hidrogênio varia de 0 a R\$ 15,00 o metro cúbico e o preço do Diesel varia de 0 a $\mathrm{R} \$ 12,00$. A velocidade do vento foi fixada em $20 \mathrm{~m} / \mathrm{s}$, uma média que fornece uma boa potência ao gerador eólico. 
Através do gráfico fica claro que em uma estreita faixa, próximo ao custo zero do hidrogênio, o uso da célula a combustível é a melhor escolha dentre as diversas opções. Outra observação relevante é que o Gerador Diesel 'Stand-alone’ não aparece entre as melhores opções para este cenário.

De forma geral, o uso da célula a combustível como componente nos sistemas híbridos só está restrita aos preços do hidrogênio. Na representação gráfica, acima de $\mathrm{R}$ \$ 3,00 e a um Diesel a R\$ 2,00, formando uma triangulação com o preço do hidrogênio a $\mathrm{R} \$ 15,00$ e um Diesel a $\mathrm{R}$ \$ 6,00, a utilização da célula a combustível tornase desfavorável.

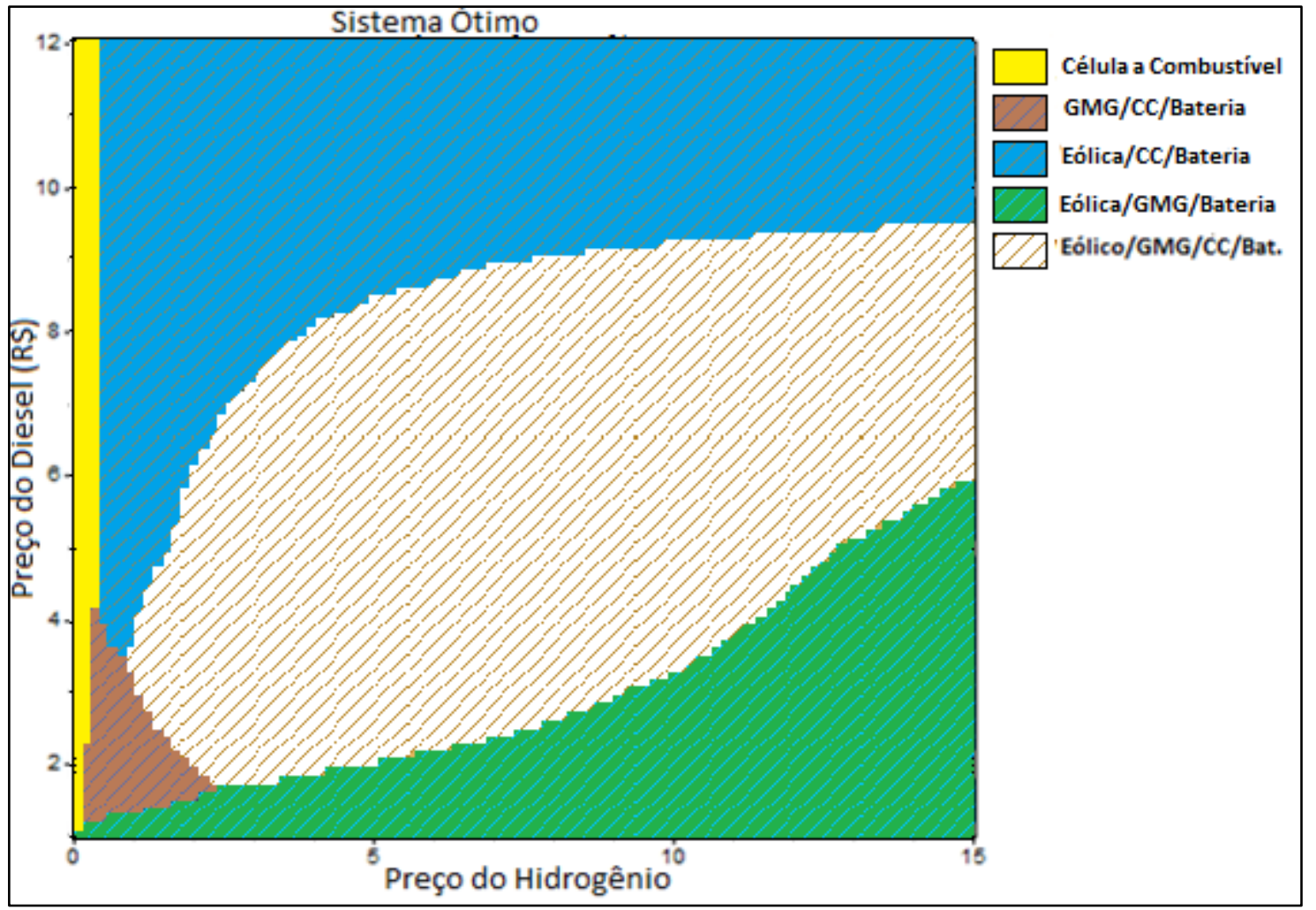

GRÁFICO 19 - Cenário 4: Célula Combustível x diesel

Os sistemas de células a combustível começarão a atender antes os sistemas distribuídos para poder, posteriormente, competir com o sistema de distribuição convencional. Isto ocorrerá por conta dos custos do sistema distribuídos que tendem a ser mais altos e pelo fato da célula combustível ser considerado um bom gerador em relação à qualidade da energia fornecida. 


\subsection{5 - Célula a Combustível x Diesel com baixa velocidade de vento}

No gráfico 20 retoma os elementos anteriores porém e a velocidade do vento foi fixada em 2,6 m/s, a média da velocidade do vento para São Paulo. Observa-se a mudanças do espaço ocupado pelos sistemas. Gerador Diesel e Célula a Combustível ganham espaço neste cenário e o Gerador Eólico perde.

Com o diesel a R\$ 9,00 ou um hidrogênio a custo zero a célula a combustível 'stand-alone' é a unidade de melhor desempenho até o preço do hidrogênio atingir R\$ 5,00 $\mathrm{m}^{3}$, onde é um Gerador Eólico é introduzido ao sistema. Com o hidrogênio ainda um pouco mais caro, na faixa de R \$ 9,00 o Gerador a Diesel volta a ganhar espaço até o limite de R\$ 6,00 L.

Observa-se ainda que a Célula a Combustível (CC) concorre diretamente com o Gerador Diesel: quanto maior o custo da fonte de um, maior a vantagem de se instalar o outro sistema. A área marrom e branca tracejda seria um meio termo entre os dois sistemas.

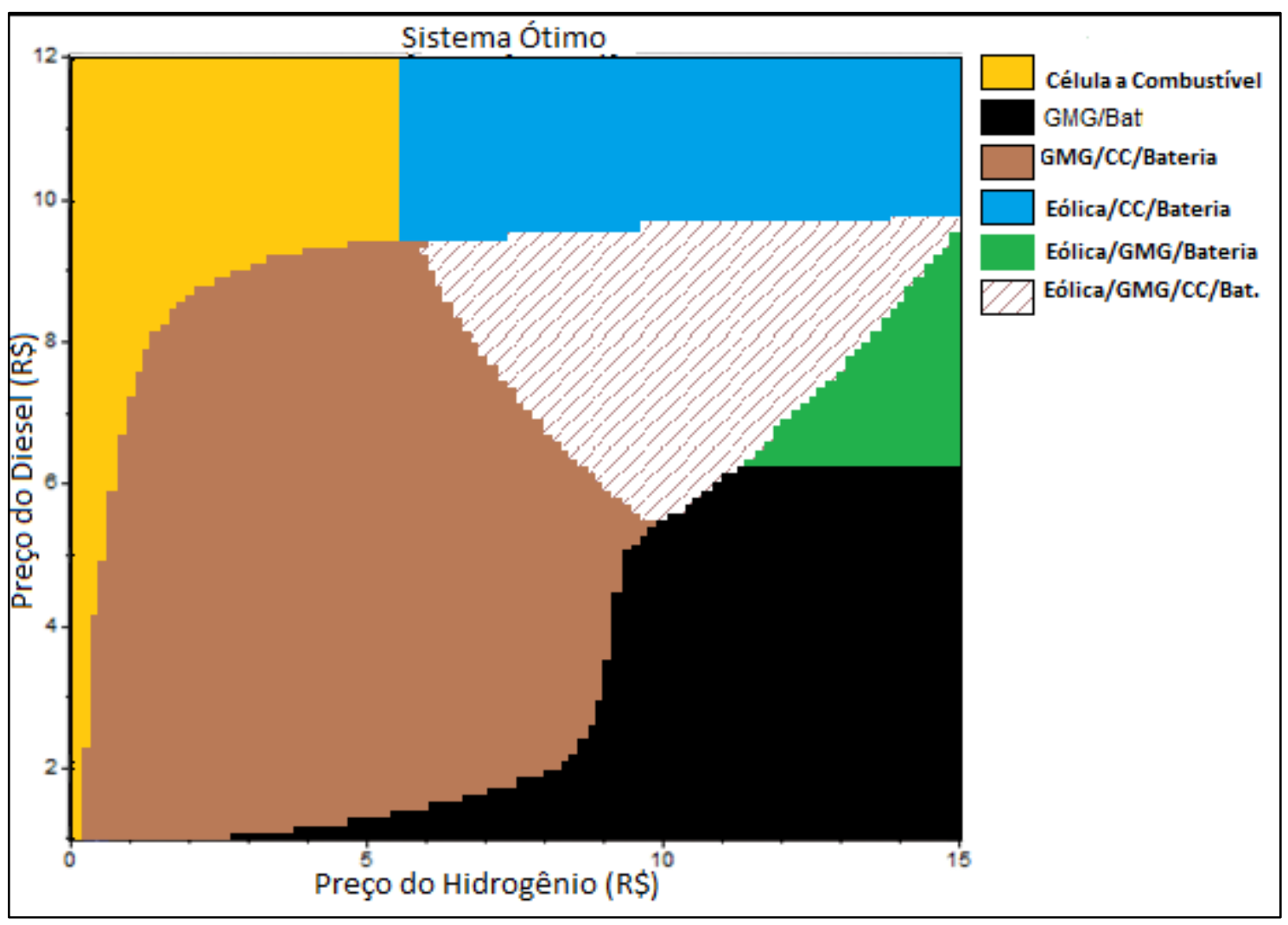

GRÁFICO 20 - Cenário 5: CC x Diesel com baixa velocidade de vento 


\subsection{6 - Geradores Sustentáveis}

No gráfico 21, todas as unidades geradoras retornam, com excessão do Gerador Diesel já que não é um gerador de energia sustentável. Encontrou-se que acima de $400 \mathrm{~L} / \mathrm{s}$ o Gerador Hídrico é a melhor opção. Abaixo, outros sistemas híbridos são melhores, a depender da velocidade do vento. O Gerador Hídrico deixa de ser uma boa opção com um fluxo de água menor que $300 \mathrm{~L} / \mathrm{s}$.

A célula a combustível neste cenário ocupa parte do lugar antes ocupado pelo Gerador Diesel mas não mesma proporção.

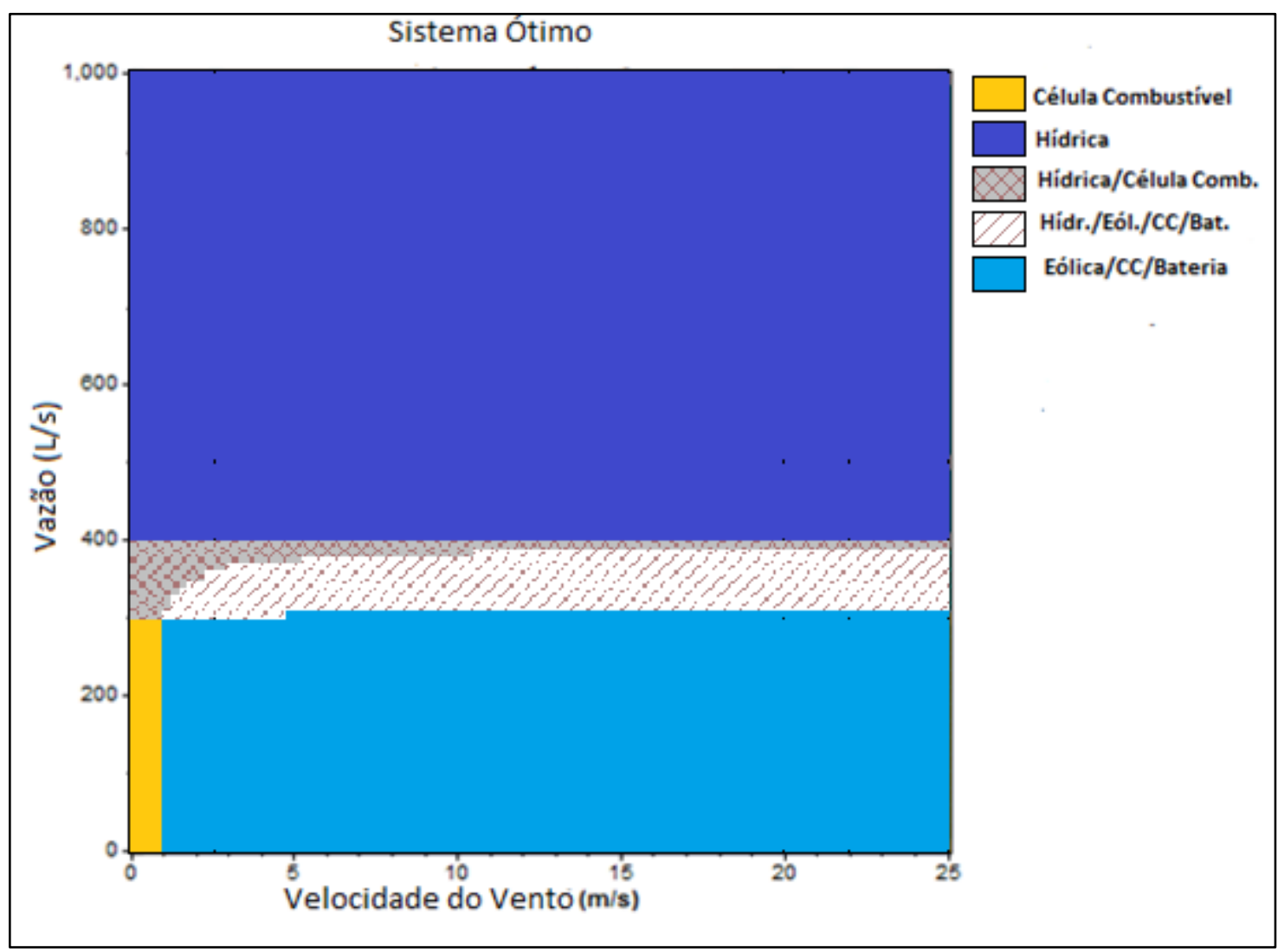

GRÁFICO 21 - Cenário 6: Geradores Sustentáveis 


\subsection{Fluxo de Caixa}

A identificação e a quantificação monetária dos custos e benefícios do projeto permitem estruturar o fluxo de caixa (FC) esperado do investimento. No gráfico 22 apresenta-se o fluxo de caixa resumido para cada ano de operação do Gerador Hídrico. O Valor residual é o valor restante dos componentes do sistema no final da vida útil do projeto. Ele existe graças a diferença entre o período de análise deste trabalho de 20 anos e a vida útil das unidades geradoras hídricas de 25 anos.

Chega-se ao final do ciclo de vida do projeto, definido em 20 anos, em um valor de -R\$552.048, o valor é negativo pois se trata de custos e não ganhos.

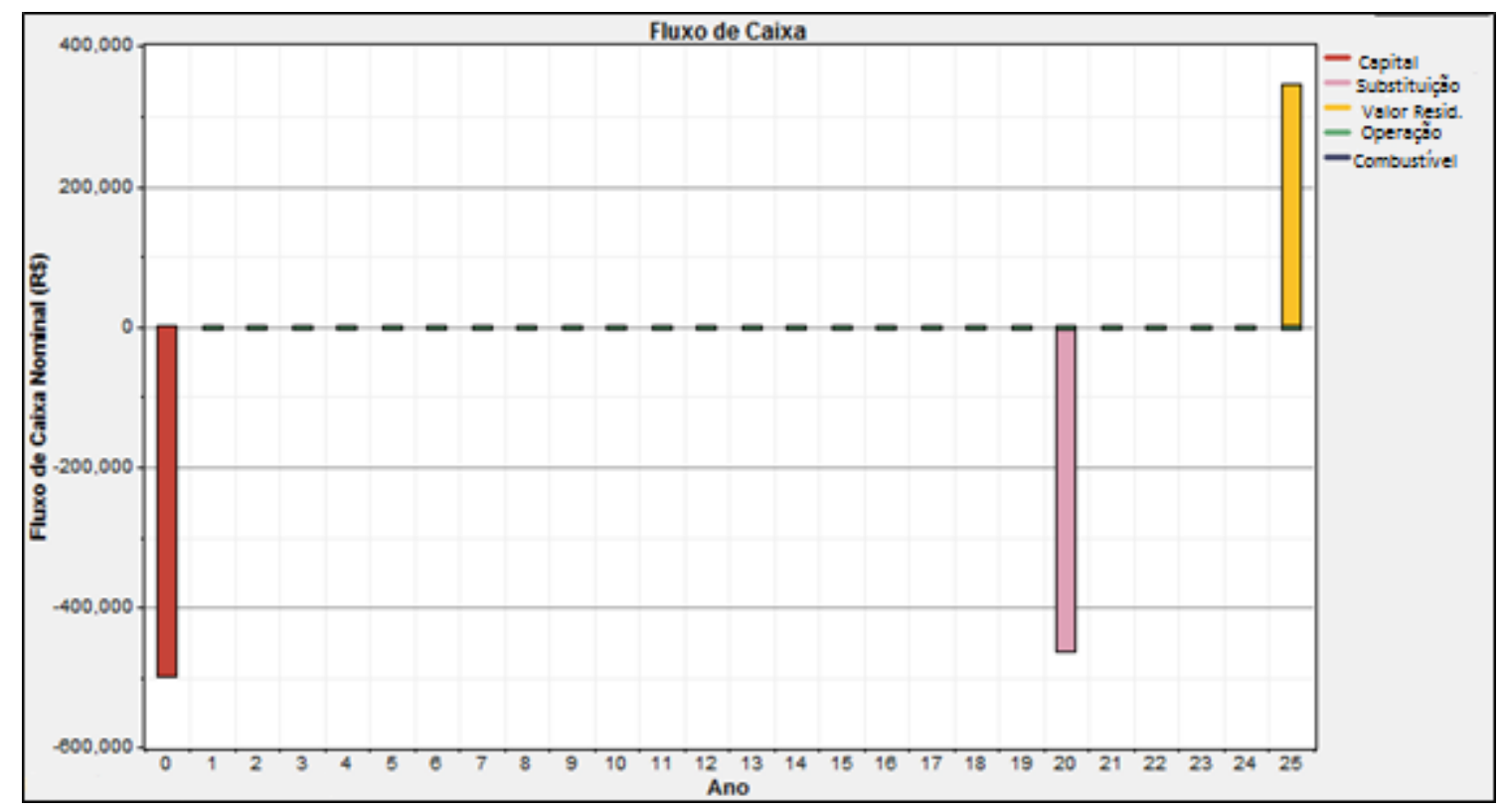

GRÁFICO 22 - Fluxo de Caixa Nominal Resumido do Gerador Hídrico 


\section{CONCLUSÕES}

Os resultados obtidos para alguns geradores podem parecer altos em um primeiro instante, mas pode ser uma saída para lugares remotos onde a rede de distribuição elétrica não alcança. É o caso de muitas regiões do Brasil, como ilhas, assentamentos, ou mesmo cidades distantes do centro de produção, onde o custo do diesel, por exemplo, graças ao custo de transporte e armazenagem, muitas vezes multiplicam seu preço final.

\section{Célula a Combustível:}

- A célula a combustível em um cenário onde é possível qualquer tipo de geração tem custo alto demais para ser implementado.

- A célula a combustível operando em 'stand-alone’ é viável economicamente atualmente se o diesel aumentar em 5 vezes.

- A célula a combustível passa a ser viável como co-gerador se o preço do diesel aumentar em 3 vezes.

- Em um cenário onde o Gerador Hídrico ou a Diesel não for possível, com o preço do hidrogênio próximo a zero, a célula combustível deve ser adotada.

- As células a combustível competirão com a rede, com um hidrogênio sem custo, se diminuírem seus custos em 4,3 vezes.

- As células a combustível competirão com a rede de distribuição, com o preço do hidrogênio nos níveis atuais se diminuírem seus custos em 31 vezes.

- Em um cenário onde apenas se podem instalar geradores sustentáveis e em condição de pouco vento e pouca água, a célula a combustível é a geração a ser implementada.

- Se o custos da célula a combustível caírem pela metade ela se tornará um forte concorrente ao Gerador a Diesel. Leva-se em conta ao seu favor a baixa emissão de poluentes no seu ciclo de vida, a alta eficiência na conversão química em elétrica, a baixa emissão de ruído. 
Eólico:

- Possuindo uma velocidade de vento acima de $9 \mathrm{~m} / \mathrm{s}$ considere incluir um Gerador Eólico. Não inclua um Gerador Eólico se não possuir pelo menos ventos de $6 \mathrm{~m} / \mathrm{s}$.

- Em um cenário onde o Gerador Hídrico não for possível e obtendo-se uma velocidade de vento acima de 8,5 m/s, um Gerador Eólico poderá ser implantado ou incluído em sistema híbrido.

Hídrico:

- Este gerador foi o que apresentou as melhores resultados.

- Havendo um fluxo de água acima de $400 \mathrm{~L} / \mathrm{s}$ e um desnível de $34 \mathrm{~m}$ o Gerador Hídrico deve ser o implantado.

- Com um fluxo de água menor que $300 \mathrm{~L} / \mathrm{s}$ deixa de ser recomendado.

Diesel:

- Em um cenário onde o Gerador Hídrico não for possível, com uma velocidade de vento inferior a $10 \mathrm{~m} / \mathrm{s}$, com o preço do diesel abaixo de R\$ 10,00, e em cenário onde não se exige controle de gases poluentes 0 Gerador Diesel deve ser implantado. A cidade de São Paulo está contida dentro destes parâmetros, indicando que este tipo de gerador deverá ser implantado se não houver uma restrição ambiental.

- Este gerador possui um custo de operação caro frente as demais unidades resultante do custo do combustível e manutenção.

- Torna-se competitivo principalmente se vazão disponível de água do local for menor que $300 \mathrm{~L} / \mathrm{s}$. 
- O custo desta tecnologia não é competitivo para as condições deste estudo.

- Com os estudos realizados pode-se chegar à conclusão de que Placas solares, com intuito de produzir eletricidade, ainda precisam melhorar a potência por metro quadrado.

Geração Distribuída:

- O sistema distribuído é, de uma forma geral, mais caro que o fornecido pelas distribuidoras.

- Para longas distâncias os sistemas distribuídos passam a ser vantajosos devido ao custo da ampliação da rede até o centro consumidor.

- Os preços das distribuidoras de energia variam enormemente no Brasil. Por esta razão este estudo recomenda a análise criteriosa, de acordo com os preços praticados pelas concessionárias, para determinação da viabilidade da implantação dos diferentes sistemas. Desta forma, alguns nichos onde a energia é mais cara podem ser explorados para a implantação dos sistemas híbridos.

- Dentro deste contexto, as energias renováveis apresentam-se como parte da solução adequada para responder às demandas devido a: benefícios intrínsecos da sua adoção; insumos em larga escala disponíveis no Brasil; rapidez na implantação; ampliação do desenvolvimento socioeconômico local; geração próxima ao centro de carga; reduções de perdas de transmissão e complementaridade às energias convencionais.

Software:

- O software HOMER apresenta algumas restrições em relação ao seu uso que afetam seu desempenho e limitam sua capacidade como ferramenta útil. Apesar de seu bom desempenho na modelagem técnica, não é 
possível o acesso aos códigos e expressões, por isto é necessário complementá-lo com técnicas econômicas para sua completa validação para projetos deste tipo.

Viabilidade:

- Os dados encontrados neste trabalho indicam a viabilidade de unidades geradoras de energia elétrica distribuída, portanto as políticas governamentais podem incentivar seu uso.

\section{1 - Conclusões de cunho Metodológico:}

Para a obtenção dos resultados dividiu-se os procedimentos técnicos em três conjuntos de ações, proposto anteriomente por Lorenzi (2009). A primeira ação foi a investigativa, baseada na obtenção de dados primários e secundários. No qual seus procedimentos foram a revisão bibliográfica e obtenção de dados. Seus objetivos concluídos foram:

- Entender o contexto de atuação da pesquisa;

- Identificar as Unidades Geradoras de Energia Sustentáveis mais relevantes com base no uso e nas tendências;

- Levantar as características técnicas das diferentes Unidades Geradoras de Energia Elétrica (UGEE) escolhidas;

- Estudar os princípios de funcionamento das diferentes UGEE escolhidas;

- Pesquisar as fontes de energia ligadas as UGEE escolhidas;

- Levantar os custos das diferentes UGEE;

- Levantar as emissões gasosas das UGEE;

- Estudar e limitar a atuação das UGEE dentro do contexto proposto;

- Estudar o funcionamento da simulação;

- Levantar dados e adaptá-los as exigências do software;

- Observar se os resultados da simulação estão de acordo com o esperado; 
Segundo, a ação analítica, fundamentada na análise e discussão dos dados obtidos, no qual seu procedimento foi a análise comparativa dos geradores. Seus objetivos concluídos foram:

- Comparar os custos das unidades geradoras;

- Comparar os resultados com a rede disponível em termos de custos;

- Determinar e analisar os cenários propostos;

Terceiro a ação propositiva, a apresentação das principais conclusões do estudo e recomendações.

\section{2 - Características Metodológicas deste trabalho:}

Quanto à natureza da pesquisa esta pode ser considerada como aplicada já que objetiva gerar conhecimentos para aplicação prática e dirigidos à solução de problemas específicos. Envolve verdades e interesses locais.

Quanto ao objetivo esta pode ser considerada como exploratória já que visa proporcionar maior familiaridade com o problema com vistas a torná-lo explícito ou a construir hipóteses. Assume, de forma geral, as linhas gerais de pesquisas bibliográficas e estudos de caso.

Quanto à forma de abordagem é de caráter majoritariamente quantitativa, considerando que a maior parte dos resultados pode ser traduzida em números, opiniões, e informações para classificá-las e analisá-las.

Quanto aos procedimentos técnicos esta pode ser considerada como pesquisa experimental já que se determina um objeto de estudo, selecionam-se as variáveis que seriam capazes de influenciá-lo, definem-se as formas de controle e de observação dos efeitos que a variável produz no objeto. 


\section{3 - Sugestões para trabalhos futuros}

- Aprofundar na análise do modelo, através da disciplina métodos quantitativos, levantando todas as equações para validação do software.

- Estudar a cadeia da Biomassa com a célula a combustível nos mesmos moldes deste trabalho

- Incluir o Mercado de Carbono, observando o seu impacto nos custos.

- Comparar os custos da geração distribuída com as tarifas horo sazonais disponíveis no local.

- Observar as modalidades de financiamento disponíveis para implantação de geradores limpos disponíveis na região e seu impacto nos resultados.

- Observar o impacto que os impostos têm sobre os custos.

- Concentrar-se na produção de hidrogênio a partir do etanol e seus efeitos sobre os custos da célula a combustível.

- Analisar a possibilidade de usar a Teoria das Opções Reais (TOR).

- Avaliar a possibilidade de cruzar os dados de custos obtidos no trabalho com os valores das tarifas disponíveis dentro das empresas, levantando assim as condições para a observação da viabilidade da implantação destes sistemas nas empresas atendidas pelas tarifas mais altas. 
APÊNDICE A - Tarifas - Principais Concessionárias

\begin{tabular}{|c|c|c|}
\hline Concessionária & Área de atuação & $\begin{array}{c}\text { Valor Tarifa Residencial* } \\
\text { (R\$/KWh) }\end{array}$ \\
\hline Enersul & Mato Grosso do Sul & 0,43364 \\
\hline Cemig & Minas Gerais & 0,43315 \\
\hline Celtins & Tocantins & 0,42854 \\
\hline Cataguazes-Leopoldina & Parte de Minas Gerais & 0,41928 \\
\hline Cemar (interligado) & Maranhão & 0,37708 \\
\hline Coelba & Bahia & 0,36964 \\
\hline Cepisa & Piauí & 0,36160 \\
\hline Ampla & Parte do Rio de Janeiro & 0,35973 \\
\hline Saelpa & Paraíba & 0,35072 \\
\hline Ceal & Alagoas & 0,34190 \\
\hline Celpe & Pernambuco & 0,33822 \\
\hline Coelce & Ceará & 0,33338 \\
\hline RGE & Parte do Rio Grande do Sul & 0,32974 \\
\hline Cemat (interligado) & Mato Grosso & 0,32881 \\
\hline Energipe & Sergipe & 0,31018 \\
\hline Boa Vista & Capital de Roraima & 0,30330 \\
\hline Light & Parte do Rio de Janeiro & 0,30180 \\
\hline CEEE & Parte do Rio Grande do Sul & 0,30071 \\
\hline Celesc & Santa Catarina & 0,30017 \\
\hline Elektro & Parte de São Paulo & 0,29865 \\
\hline Celg & Goiás & 0,29353 \\
\hline AES - Sul & Parte do Rio Grande do Sul & 0,29117 \\
\hline Escelsa & Espírito Santo & 0,28916 \\
\hline Cosem & Rio Grande do Norte & 0,28797 \\
\hline CER & Estado de Roraima & 0,28066 \\
\hline Ceam & Amazonas & 0,27847 \\
\hline CPFL - Piratininga & Parte de São Paulo & 0,27464 \\
\hline Manaus - Energia & Manaus - Capital & 0,27322 \\
\hline Celpa (interlligado) & Pará & 0,26786 \\
\hline Bandeirante & Parte de São Paulo & 0,26782 \\
\hline Copel & Paraná & 0,25555 \\
\hline CEB & Distrito Federal & 0,25162 \\
\hline Eletropaulo & Parte de São Paulo & 0,24606 \\
\hline
\end{tabular}

* Tarifas vigentes até 2008

Tarifas Residenciais Vigentes até 2008 - Principais Concessionárias 


\section{REFERÊNCIAS BIBLIOGRÁFICAS}

ACKERMANN, T.; ANDERSON, G.; SÖDER, L.; Distributed generation: $a$ definition. Electric Power Systems Research 57, 195-204, Elsevier, 2001.

ASSOCIAÇÃO BRASILEIRA DE NORMAS TÉCNICAS. NBR 6023: Informação e documentação - Referências - Elaboração. ABNT, Rio de Janeiro, 2000.

ASSOCIAÇÃO BRASILEIRA DE NORMAS TÉCNICAS. NBR 10520: Informação e documentação - Apresentação de citações em documentos. ABNT, Rio de Janeiro, 2001.

ASSOCIAÇÃO BRASILEIRA DE NORMAS TÉCNICAS. NBR 14724: Informação e documentação - Trabalhos acadêmicos - Apresentação. ABNT, Rio de Janeiro, 2001.

AGÊNCIA NACIONAL DE ENERGIA ELÉTRICA - ANEEL. Tarifas de fornecimento de energia elétrica. Cadernos Temáticos, ANEEL, Brasília, 2005.

AGÊNCIA NACIONAL DE ENERGIA ELÉTRICA - ANEEL. Resolução $n^{\circ} 456$, de 29 de novembro de 2000 - Estabelece, de forma atualizada e consolidada, as Condições Gerais de Fornecimento de Energia Elétrica. ANEEL, Brasília, 2000.

AGÊNCIA NACIONAL DE ENERGIA ELÉTRICA - ANEEL. [a] Relatórios do Sistema de Apoio a Decisão. Disponível em <http://www.aneel.gov.br/area.cfm?idArea=550> ANEEL, Brasília, 2011a.

AGÊNCIA NACIONAL DE ENERGIA ELÉTRICA - ANEEL. [b] Geração Hídrica. Disponível em <http://www.aneel.gov.br/aplicacoes/atlas/energia_hidraulica/4_3.htm> ANEEL, Brasília, 2011b.

AGÊNCIA NACIONAL DE ENERGIA ELÉTRICA - ANEEL. [c] Energia Eólica. Disponível em <http://www.aneel.gov.br/aplicacoes/atlas/energia_eolica/6_3.htm> ANEEL, Brasília, 2011c.

AGÊNCIA NACIONAL DE ENERGIA ELÉTRICA - ANEEL. [d] Energia Solar. Disponível em <www.aneel.gov.br/aplicacoes/atlas/energia_solar/3_3.htm> ANEEL, Brasília, 2011d.

AGÊNCIA NACIONAL DE ENERGIA ELÉTRICA -ANEEL[a], resolução nº 394 de 1998, Brasília, 1998a.

AGÊNCIA NACIONAL DE ENERGIA ELÉTRICA -ANEEL[b], resolução nº 395 de 1998, Brasília, 1998b.

AGÊNCIA NACIONAL DE PETROLEO - ANP. Disponível em < www.anp.gov.br/> Acesso em dezembro de 2010. 
ALBUQUERQUE, V. O.; PAMPLONA, E. O.; JUNIOR, C. G. Avaliação Econômica de Investimentos em Energia Elétrica Considerando Riscos e Incertezas. Simpósio de Especialistas em Planejamento da Operação e Expansão Elétrica, XI. Bélem, 2009.

AL-KARAGHOULI; L.L. KAZMERSKI. Optimization and life-cycle cost of health clinic PV system for rural área in southern Iraq using Homer software. Solar Energy, v.84, p. 710-714, Elsevier, 2010.

ALMEIDA FILHO, R. G. Planejamentos Fatoriais Fracionados para Análise de Sensibilidade de Modelos de Simulação de Eventos Discretos. Dissertação em Engenharia de Produção. Universidade Federal de Itajubá - UNIFEI, Itajubá, 2006.

ALMEIDA, S. C. A; FREIRE, R. L.; Análise de Viabilidade de Implantação de Fontes Alternativas de Energia no Hospital das Clínicas UNICAMP. $\mathbf{7}^{\mathbf{0}}$ Congresso Internacional sobre Geração Distribuída e Energia no Meio Rural. Campinas, 2008.

BANCO CENTRAL DO BRASIL - BCB. Calculadora do Cidadão. Disponível em $<$ https://www3.bcb.gov.br/CALCIDADAO/publico/exibirFormCorrecaoValores.do?me thod=exibirFormCorrecaoValores> Acesso em fevereiro de 2011.

BANKS, J.; CARSON, J. S.; NELSON, B. L.; NICOL, D. M. Discrete-event system simulation. 4th ed.: Prentice Hall. New Jersey p. 608, 2005.

BECCALI, M; BRUNONE, S; CELLURA M, FRANZITTA, V. Energy, economic and environmental analysis on RET-hydrogen systems in residential buildings, Renewable Energy, Volume: 33 Issue: 3 pp: 366-382, 2008.

BEtarello, A. C. T. Micro Central Elétrica - MCH: Potência de 1 a 100kW; Central Geradora Hidrelétrica - CGH: 100 a 500kW. Betta Hidroturbinas. Franca, 2009.

BRAGA, J. M. F.; SEIDL, P.; LONGO, W. P. Análise da Viabilidade Econômica da Integração de Células a Combustível nas Plantas de Cloro-Soda para Utilização do Hidrogênio gerado no processo. Engevista, vol. 11, No 1, pags. 8-23, Niterói, 2009.

BRASIL. Decreto-Lei $n^{\circ} 5.163$ de 30 de julho de 2004. Regulamenta a comercialização de energia elétrica, o processo de outorga de concessões e de autorizações de geração de energia elétrica, e dá outras providências. Brasília, 2004.

BRITO, M. L. S.; E CASTRO, P. M.; Viabilidade Econômica de Redes de Distribuição Protegidas. Revista Da Sociedade Brasileira De Arborização Urbana, Volume 2, Número 1, Viçosa, 2007.

BP. BP Statistical Review of World Energy June 2010. BP. London, 2010.

CALIFORNIA DISTRIBUTED ENERGY RESOURCES GUIDE - DER. Disponível em <http://www.energy.ca.gov/distgen/index.html> Acesso em março de 2011. 
CAMARA, E. Energias mais renováveis que as outras. BBC BRASIL, Londres, 2011. Disponível em <http://www.bbc.co.uk/blogs/portuguese/planeta_clima/> Acesso em abril de 2011.

CAMARGO, A. S. G. Análise da Operação das Usinas Eólicas de Camelinho e Palmas e Avaliação do Potencial Eólico de localidades no Paraná. CEFET, Curitiba, 2005.

CGEE - CENTRO DE GESTÃO E ESTUDOS ESTRATÉGICOS. Energias do Futuro, CGEE, Brasília, 2008.

COGEN - ASSOCIAÇÃO FLUMINENSE DE COGERAÇÃO DE ENERGIA. Disponível em <http://www.cogenrio.com.br/Prod/OQueEGeracaoDistribuida.aspx> Acesso em: janeiro de 2010.

COMPANHIA HIDRO ELÉTRICA DO SÃO FRANCISCO - CHESF. O Brasil no Contexto das Fontes Renováveis e da Eficiência Energética. Portal Corporativo da CHESF. Disponível em <http://www.chesf.gov.br/portal/page/portal/chesf_portal/ paginas/sistema_chesf/sistema_chesf_fontes_renovaveis/conteiner_fontes_renovaveis> Acesso em abril de 2011.

CONEJERO M. A. Marketing de Créditos de Carbono: Um Estudo Exploratório. Dissertação de mestrado em Administração. FEA/USP. Ribeirão Preto, 2006.

DEMIROREN, A.; YILMAZ, U. Analysis of change in eletric energy cost with using renewable energy sources in Gökceada, Turkey: An island example. Renewable and Sustainable Energy Reviews, Elsevier, 2009.

DEPARTAMENTO INTERSINDICAL DE ESTATÍSTICA E ESTUDOS SOCIOECONÔMICOS - DIEESE. Índice do boletim DIEESE - Estudos e Pesquisas. Disponível em: <http://www.dieese.org.br/bol/esp/estjul98.xml> Acesso em setembro de 2010.

DEPARTAMENTO INTERSINDICAL DE ESTATÍSTICA E ESTUDOS SOCIOECONÔMICOS - DIEESE. As tarifas de energia elétrica no Brasil: sistemática de correção e evolução dos valores - Nota Técnica, $n^{\circ}$ 58. DIEESE, São Paulo, 2007.

DEPARTMENT OF ENERGY HYDROGEN INFORMATION NETWORK - DOE U.S. - Disponível em <http://www.eren.doe.gov/hydrogen/faqs.html\#cost> Acesso em setembro de 2010, informação de 2002.

DIAS, M. V. X.; BOROTNI, E. C.; HADDAD, J. Geração distribuída no Brasil: oportunidades e barreiras. SBPE - Revista Brasileira de Energia. Vol. $11 \mathrm{~N}^{\mathrm{o}} 2$. Itajubá, 2005.

. ELETROBRÁS. Diretrizes para Projetos de PCH. Cap. 2. 1999.

ELECTROCELL. O que é célula a combustível. Como funciona a célula a combustível? Disponível em <http://www.electrocell.com.br/oqueeacc_pt.htm>Acesso em junho de 2011. 
EMPRESA DE PESQUISA ENERGÉTICA - EPE [a]. Projeção da demanda de energia elétrica para os próximos 10 anos (2011-2020). Série Estudos de Energia Nota técnica DEA 03/11, EPE, Rio de Janeiro, 2011a.

EMPRESA DE PESQUISA ENERGÉTICA - EPE [b]. Informe à Imprensa. Demanda de energia elétrica - 10 anos. EPE, Rio de Janeiro, 2011b.

EXAME - Revista Exame.com apud AFP - AGENCE FRANCE PRESSE. Energia eólica foi a mais utilizada na Espanha em março. Seção: Economia / Meio Ambiente e Energia / Fontes Renováveis. Disponível em $<$ http://exame.abril.com.br/economia/meio-ambiente-e-energia/noticias/energia-eolicafoi-a-mais-utilizada-na-espanha-em-marco--2> Acesso em março de 2011.

FARRET, F. A.; SIMÕES M. G.; Integration of alternative sources of energy. WileyInterscience, IEEE, Hoboken, New Jersey and Canada, 2006.

FLORIO, M.; FINZI, U.; GENCO, M.; LEVARLET, F.; MAFFII, S.; TRACOGNA, A.; VIGNETTI, S. Manual de Análise dos Custos e Benefícios dos Grandes Projetos. Fundos estruturais - FEDER, Fundo de Coesão e ISPA. Comunidade Européia, 2003.

HENRIQUES Jr., M. F. H.; SZKLO, A. S. Implantação de Unidades de Geração de Energia Eólica em Comunidades Rurais de Regiões Remotas - O Caso Do Vale Do Rio $S$. Francisco - Bahia. AGRENER $\mathbf{7}^{\mathbf{0}}$ - Congresso Internacional sobre Geração Distribuída e Energia no Meio Rural. Campinas, 2008.

HERMSDORFF, W.; OLIVEIRA D. F.; Geração Independente da Ponta. In Procedings of the $3^{\circ}$ Encontro de Energia no Meio Rural, Campinas, 2000.

HINRICHS, R. A.; KLEINBACH, M. Energia e Meio Ambiente. Thomson, New York, 2003.

HOMER ENERGY. Optimizing Clean Power Everywhere. Disponível em $<$ http://www.homerenergy.com/> Acesso em 2011.

IGAMI, M.P.Z.; ZARPELON, L.M.C. (Org). Guia para a elaboração de dissertações e teses: preparado para orientação dos alunos de Pós-graduação do IPEN. São Paulo: IPEN, Divisão de Informação e Documentação Científicas, São Paulo, 2002.

INTERGOVERNAMENTAL PANEL ON CLIMATE CHANGE - IPCC. Potential of Renewable Energy Outlined in Report by the Intergovernmental Panel on Climate Change. Press Release, Abu Dhabi, 2011.

KANASE-PATIL, A.B.; R.P. SAINI,; M. P. SHARMA. Integrated renewable energy systems for off grid rural electrification of remote area. Renewable Energy, v. 35. p. 1342-1349, Elsevier, 2009

KHAN, M J; IQBAL, M. T. Pre-feasibility study of stand-alone hybrid energy systems for applications in Newfoundland. Renewable Energy, Volume: 30 Issue: 6 Pages: 835-854, 2005. 
LAMBERT, T. HOMER'S HELP GUIDE. In: software HOMER. Disponível em $<$ http://www.homerenergy.com/> Acesso em março de 2010.

LECOCQ, F.; AMBROSI, P. The Clean Development Mechanism: History, Status, and Prospects. Oxford Journals - Rev Environmental Economics and Policy. Volume1, Issue 1 P. 134-151, 2007.

LEME, A. A. A Reforma do Setor Elétrico no Brasil, Argentina e México: contrastes e perspectivas em debate. Rev. Sociol. Polít. V. 17, n. 33, p. 97-121. Curitiba, 2009.

LEVENE, J.; KROPOSK, B.; SVERDRUP, G. Wind Energy and Production of Hydrogen and Electricity - Opportunities for Renewable Hydrogen. POWER-GEN Renewable Energy and Fuels Technical Conference. Las Vegas, 2006.

LINARDI, M. Hidrogênio e Células Combustíveis. (2010a) Disponível em <http://ecen.com/eee66/eee66p/hidrogenio_e_celulas_a_combustivel.htm> Acesso em setembro de 2010a.

LINARDI, M. Introdução à Ciência e Tecnologia de Células a Combustível. (2010b) Artliber Editora, São Paulo 2010.

LISBOA, A. H. Desafios e oportunidades na utilização Eólica e a experiência da CEMIG. CEMIG, Belo Horizonte, 2010.

LORA, E. S.; HADDAD, J. Geração Distribuída Aspectos Tecnológicos, Ambientais e Institucionais. Editora Interciência. Rio de Janeiro, 2006.

LORENZI, C. E. Impactos Ambientais e Energéticos provocados pela substituição de motores de combustão interna por células a combustível em veículos automotores. Dissertação de Mestrado Engenharia de Processos Químicos e Bioquímicos. São Caetano do Sul, 2009.

LOURENÇO, S. R. Uma contribuição para inserção do gás natural como alternativa viável na matriz energética nacional. Tese em Doutorado em Engenharia Química. UNICAMP, Campinas, 2006.

LUCCHESE, F. A.; SOARES J. C. Micro centrais hidroelétricas- uma proposta de energia alternativa para o meio rural da região noroeste/RS. XXII Encontro Nacional de Engenharia de Produção. Curitiba 2002.

MARCHETTI, V. Risco e Decisão em investimento produtivo. Editora Universidade, UFRGS, Porto Alegre, 1995.

MARINOSK, A. K.; GHISI, E. Aproveitamento de água pluvial para usos não potáveis em instituição de ensino: estudo de caso em Florianopólis - SC. Ambiente Construído, v. 8, n. 2, p. 67-84, Porto Alegre, 2008.

MENDONÇA, R. R. S. Sumário da disciplina Metodologia Científica em Administração. UFJF, Juiz de Fora, 2003. 
MINISTÉRIO DE MINAS E ENERGIA - MME. Resenha Energética Brasileira Exercício de 2007 . Brasília, 2008.

MINISTÉRIO DE MINAS E ENERGIA - MME. Resenha Energética Brasileira Exercício de 2008. Brasília, 2009.

MINISTÉRIO DE MINAS E ENERGIA - MME. Resenha Energética Brasileira Exercício de 2009 (preliminar). Brasília, 2010.

MOREIRA, J. R.; COELHO, S. T.; ALMEIDA, M. C.; PECORA, V.; PRADO, T. G. Externalidades associadas à geração distribuída de energia elétrica a partir de biomassa na indústria sucroalcooleira. In.: Procedings of the 5th Encontro de Energia no Meio Rural, Campinas, 2004.

MORIARTY P.; HONNERY D. Hydrogen's Hole in an uncertain energy future. International Journal of Hydrogen Energy, 34, 31-39, Elsevier, 2009.

NATIONAL AERONAUTICS AND SPACE ADMINISTRATION - NASA. Surface meteorology and Solar Energy (SSE) Release 6.0 Methodology. 2009.

NATIONAL RESEARCH COUNCIL - NRC e NATIONAL ACADEMIC OF ENGINEERING -NAE. The Hydrogen Economy - Opportunities, Costs, Barriers, and $R \& D$ Needs. The national academies press, Washington, 2004.

NATIONAL RENEWABLE ENERGY LABORATORY - NREL. Disponível em $<$ http://www.nrel.gov/ > Acesso em setembro de 2010.

NATIONAL RENEWABLE ENERGY LABORATORY - NREL. Getting Started Guide For HOMER Version 2.1. Office of Energy Efficiency and Renewable Energy by Midwest Research Institute - Golden e Battelle, 2005.

NICHOLSON, W. Fire and Cooking in Human Evolution, Rates of Genetic Adaptation to Change, Hunter-Gatherers, and Diseases in the Wild. Disponível em $<$ http://www.beyondveg.com/nicholson-w/hb/hb-interview2a.shtml> Acesso em maio de 2011, informação de 1996.

NISHI, M, H.; JACOVINE, L. A. G; da Silva, M. L.; Renato VALVERDE, S. R.; NOGUEIRA, H. P.; e ALVARENGA, A. P. Influência dos Créditos de Carbono na Viabilidade Financeira de Três Projetos Florestais. SIF - Sociedade de Investigações Florestais, v.29, n.2, p.263-270, Viçosa, 2005.

OCÁCIA, G. C.; BRISTOTI, A; JORGE, R. R.; BALBINOT, A; O fator de carga no custo do KWH em micros centrais hidrelétricas isoladas. In: Encontro de Energia no Meio Rural, 4. Campinas, 2002.

PARANHOS, J. R. M. R.; ARPON, E. J. A.; IMPINNISI, P. R. Experiência de Um ano de Operação de uma Célula a Combustível de 200 kW. Seminário Nacional de Distribuição de Energia Elétrica, XV, 2002. 
PER - PORTAL DAS ENERGIAS RENOVÁVEIS. Hidrogénio. Tecnologias: Fuel Cells. Disponível em: <http://www.energiasrenovaveis.com/DetalheConceitos.asp? ID_conteudo=28\&ID_area=6\&ID_sub_area=18 $>$ Acesso em junho de 2011. Informações de 2009.

PILÃO, N.E.; HUMMEL, P.R.V. Matemática Financeira e Engenharia Econômica: A teoria e a prática da análise de projetos de investimentos. Pioneira Thomson Learning. São Paulo, 2003.

PINHO, J. T.; BARRETO, E. J. F.; BARBOSA, C. F. O.; PEREIRA, E. J. S.; SOUZA, H. M. S.; BLASQUES, L. C. M.; GALHARDO, M. A. B.; MACÊDO, W. N. Sistemas Híbridos - Soluções Energéticas para a Amazônia. MME, Brasília, 2008.

PINI. Disponível em <http://www.piniweb.com.br/> Acesso em janeiro de 2011.

PORTAL H2. White Martins prevê crescimento de até 15\% no faturamento. Disponível em <http://www.portalh2.com.br/index.asp> notícia vinculada em 2006.

PORTELA, F. Apud ONS - OPERADOR NACIONAL DO SISTEMA. Esperança no “chapéu chinês”. Revista Veja, edição 2151 - ano 43 - nº 6, Editora Abril, São Paulo, 2010.

REMICK, R.; WHEELER, D. Molten Carbonate and Phosphoric Acid Stationary Fuel Cells: Overview and Gap Analysis. Solutions for Alternative Energy, 2009.

RETSCREEN. RETScreen Climate Database. In: Software RETScreen. RETScreen International, CanmetENERGY, Natural Resources Canada. Varennes, 1997-2011.

RIBEIRO, F. S.; KURAHASSI, L. F.; PAZZINI, L. H. A.; GALVÃO, L. C. R.; PELEGRINI, M. A. A evolução dos custos no programa de eletrificação rural do estado de São Paulo - In Procedings of the 3. Enc. Energ. Meio Rural, Campinas, 2000.

RIFKIN, J. A Economia do Hidrogênio - A Criação de uma Nova Fonte de Energia e a redistribuição do Poder na Terra. $1^{\circ}$ ed. M. Books, São Paulo, 2003.

ROSADO Jr., A. G.; COELHO, H. M.; FEIL, N. F. Análise da viabilidade econômica da produção de bio-etanol em microdestilarias. Congresso Brasileiro de Custos, XVI. Fortaleza, 2009.

ROSS, S. A.; WESTERFIELD, R.; JORDAN, B. D. Administração Financeira. 8.ed. McGraw-Hill, São Paulo, 2008.

SANTOS, R. (comunicação pessoal) Depoimento do Gerente Geral de Vendas da Vale Soluções em Energia - VSE. 13 de maio de 2011.

SARAIVA, F. Geradores diesel: vantagens e desvantagens. Manutenções \& Suprimentos. 2011.

SENNA, R. M.; CASTRO, A. J. A. Técnicas de Procedimentos de Manutenção vol. 2. FATEP/IAT, Piracicaba, 2009. 
SILVA, E. P.; CAMARGO, J. C.; SORDI, A.; SANTOS, A. M. R. O Futuro dos Recursos: Recursos energéticos, meio ambiente e desenvolvimento. MultiCiência: Revista Interdisciplinar dos Centros e Núcleos da Unicamp. Campinas, 2003.

SILVA, E. L.; MENEZES, E. M.. Metodologia da pesquisa e elaboração de dissertação, $4^{\mathrm{a}}$ ed. rev. atual. Florianópolis: UFSC. 2005.

SIMÕES, R. A luta por energia. BBC BRASIL, Londres, 2011. Disponível em $<$ HTTP://www.bbc.co.uk/blogs/portuguese/> Acesso em abril de 2011.

SIQUEIRA, M. F.; GUIMARÃES Jr., S. C.; CAMACHO, J. R. Implantação de Fontes Alternativas de Energia no Prédio da Faculdade de Engenharia Elétrica da Universidade Federal de Uberlândia: Um Estudo de Viabilidade Econômica. III SBSE 2010- Simpósio Brasileiro de Sistemas Elétricos. Belém, 2010.

SOARES, G. F. W.; VIEIRA, L. S. R.; NASCIMENTO, M. V. G. Operação de um grupo gerador diesel utilizando óleo vegetal bruto como combustível. Encontro Energia Rural, Viçosa, 2000.

SOVACOOL, B., K. Valuing the greenhouse gas emissions from nuclear power: A critical survey. Energy Policy 36, 2940-2953. Elsevier, 2008.

SUCCAR, P. M. Estudo de Viabilidade Econômica para implantação de um gerador a diesel em condomínios residenciais. Projeto de conclusão de curso, Centro de Tecnologia - Escola Politécnica - Universidade Federal do Rio de Janeiro - UFRJ, 2008.

TERCIOTE, R. Eficiência energética de um sistema eólico isolado. In Procedings of the 4th Encontro de Energia no Meio Rural, 2002, Campinas, 2002.

TERREMOTO, L. A. (comunicação pessoal) Acidente Nuclear no Japão. Palestra. In: CEN/IPEN, 18 de maio de 2011.

TOLMASQUIM, M. T.; GUERREIRO, A.; GORINI, R. Matriz Energética Brasileira Uma Prospectiva. Novos Estudos, CEBRAP, 79, p. 47 - 69. São Paulo, nov. 2007.

TOLMASQUIM, M. T; SZKLO, A S; SOARES, J. B. In Slides of: Potential use for alternative energy sources in Brazil , Annual Petrobras Conference, 2002, Oxford, Inglaterra, 2002.

UDAETA, M. E. M.; SOUZA, C. A. F.; RIGOLIN, P. H. C. Recursos Energéticos pelo Lado da Oferta (RELO) Utilizados no PIR da RAA. Novos Instrumentos de Planejamento Energético Regional visando o Desenvolvimento Sustentável. Projeto de Pesquisa. USP/IEE. 2009.

UNITED NATIONS FRAMEWORK CONVENTION ON CLIMATE CHANGE UNFCCC [a] - Kyoto Protocol. Disponível em: <http://unfccc.int/kyoto_protocol/items/2830.php> Acesso em setembro de 2010a. 
UNITED NATIONS FRAMEWORK CONVENTION ON CLIMATE CHANGE UNFCCC [b] Disponível em <http://unfccc.int/resource/docs/convkp/kpeng.pdf> Acesso em outubro de 2010b.

UNITED NATIONS - UN. Development and International Economic Co-operation: Environment. UN, General Assembly, A/RES/42/427. 1987.

UNITED STATES DEPARTAMENT OF AGRICULTURA - USDA. Sustainable Development: Background - Sustainable Development at Home. Disponível em <http://www.usda.gov/oce/sustainable/background.htm> 2009.

VAN DEN WALL BAKE, J. D.; JUNGINGER, M.; FAAIJ, A.; POOT, T.; WALTER, A. Explaining the experience curve: Cost reductions of Brazilian ethanol from sugarcane. Biomass and Energy, v.33, p. 644 - 658, Elsevier, 2009.

VINHA, M. P.; VERISSIMO, R. A. Taxa Interna de Rentabilidade Ajustada e Payback Period. Instituto Politécnico de Coimbra. Instituto Superior de Engenharia. Coimbra, 2006. 